\title{
TSUNAMI INUNDATION MAPS OF CORDOVA AND TATITLEK, ALASKA
}

\author{
by
}

Dmitry J. Nicolsky, Elena N. Suleimani, and Rich D. Koehler

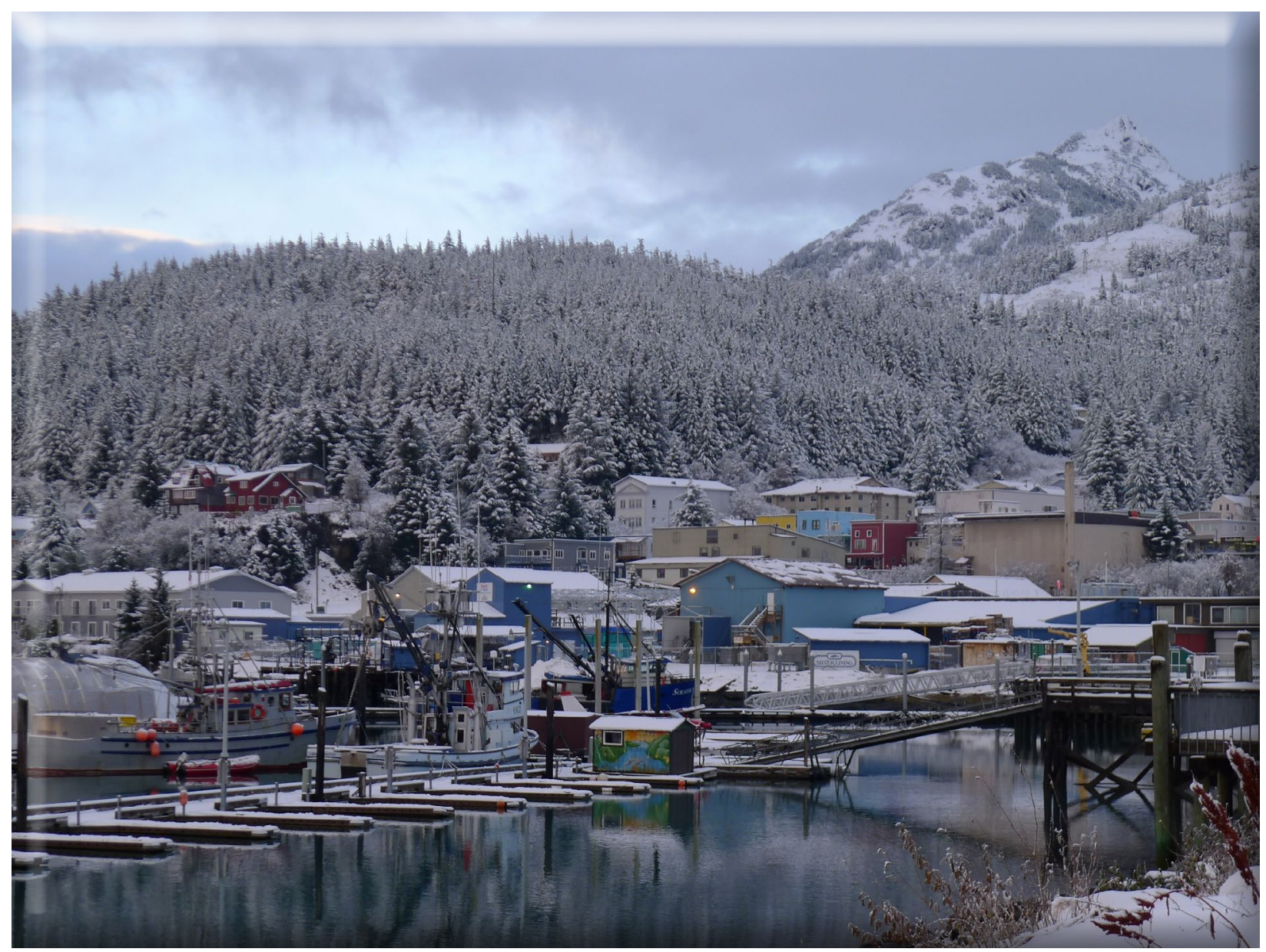

The Cordova waterfront and small boat harbor adjacent to Orca Inlet, Alaska, viewed from Nicholoff Way. Photo by Rich D. Koehler.

\section{Published by}

STATE OF ALASKA

DEPARTMENT OF NATURAL RESOURCES

DIVISION OF GEOLOGICAL \& GEOPHYSICAL SURVEYS 



\section{Report of Investigations 2014-1}

\section{TSUNAMI INUNDATION MAPS OF CORDOVA AND TATITLEK, ALASKA}

by

Dmitry J. Nicolsky, Elena N. Suleimani, and Rich D. Koehler

2014

$\$ 5.00$

This DGGS Report of Investigations is a final report of scientific research. It has received technical review and may be cited as an agency publication. 


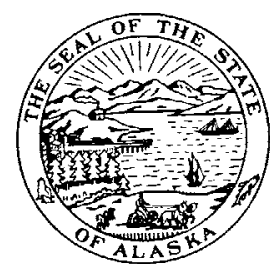

STATE OF ALASKA

Sean Parnell, Governor

DEPARTMENT OF NATURAL RESOURCES

Joe Balash, Commissioner

\section{DIVISION OF GEOLOGICAL \& GEOPHYSICAL SURVEYS \\ Steve Masterman, State Geologist and Director}

Publications produced by the Division of Geological \& Geophysical Surveys (DGGS) are available for free download from the DGGS website (www.dggs.alaska.gov). Publications on hard-copy or digital media can be examined or purchased in the Fairbanks office:

\section{Alaska Division of Geological \& Geophysical Surveys \\ 3354 College Rd., Fairbanks, Alaska 99709-3707 \\ Phone: (907) 451-5020 Fax (907) 451-5050 \\ dggspubs@alaska.gov \\ www.dggs.alaska.gov}

\begin{abstract}
Alaska State Library
State Office Building, 8th Floor 333 Willoughby Avenue

Juneau, Alaska 99811-0571

Elmer E. Rasmuson Library University of Alaska Fairbanks Fairbanks, Alaska 99775-1005
\end{abstract}

\author{
Alaska Resource Library \& Information \\ Services (ARLIS) \\ 3150 C Street, Suite 100 \\ Anchorage, Alaska 99503-3982 \\ University of Alaska Anchorage Library \\ 3211 Providence Drive \\ Anchorage, Alaska 99508-4614
}




\section{CONTENTS}

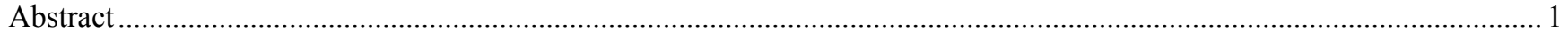

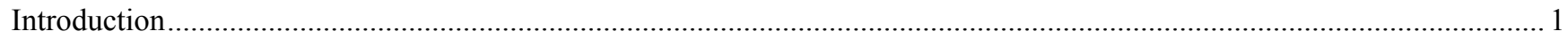

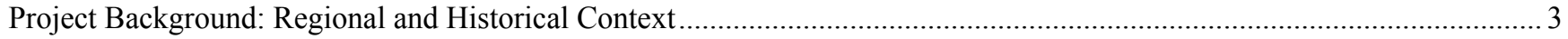

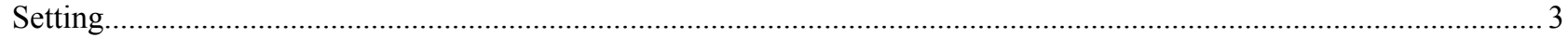

Tsunami Waves at Cordova, Alaska, on March 27, 1964 ....................................................................................... 3

Tsunami Waves in Tatitlek Narrows, Alaska, on March 27, 1964 .......................................................................... 4

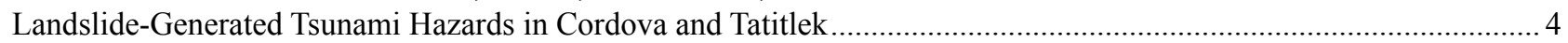

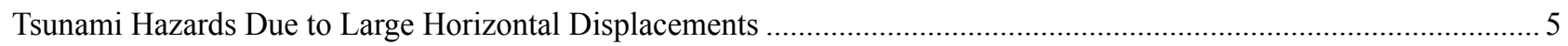

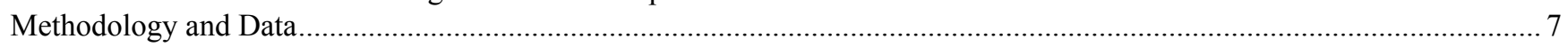

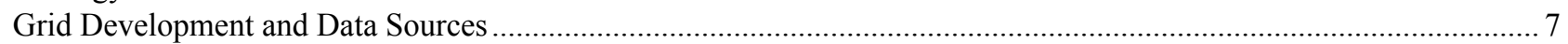

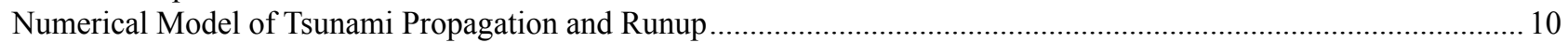



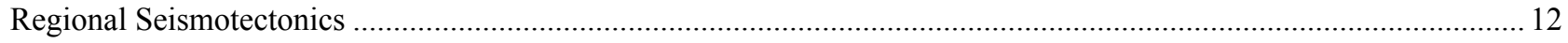

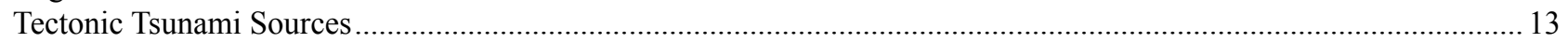

A. Models of the 1964 Great Alaska Earthquake................................................................................................. 13

Scenario 1. Repeat of the 1964 event: Source function based on coseismic deformation model by Johnson and others (1996) (JDM) ................................................................................................................. 14

Scenario 2. Repeat of the 1964 event: Source function based on coseismic deformation model by Suito

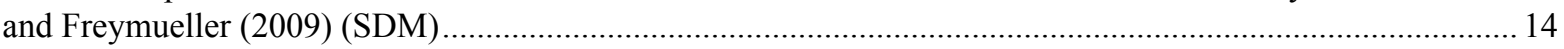

B. Models of a Multi-Segment Earthquake: Kodiak Island, Prince William Sound, and YY Asperities ....................... 14

Scenario 3. Multi-Segment JDM event: Source function based on extension of the JDM...................................... 16

Scenario 4. Multi-Segment SDM event: Source function based on extension of the SDM ................................... 16

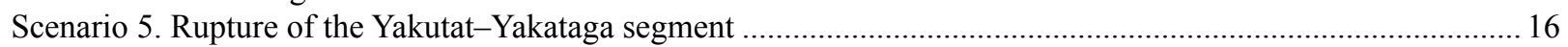

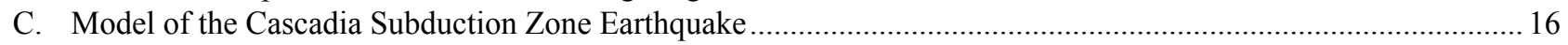

Scenario 6. Rupture of the Cascadia subduction zone, including portions of the margin along the British

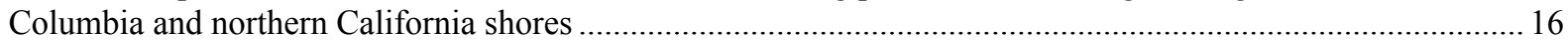

D. Tectonic Source Models of Hypothetical Tsunamigenic Earthquakes in the Yakutat Block ................................... 16

E. Tectonic Source Models of Hypothetical Tsunamigenic Earthquakes Associated with Subsidence in Cordova

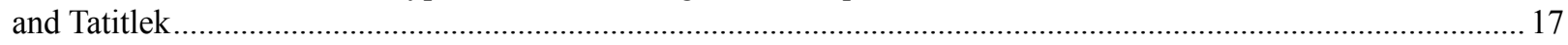

Scenario 7. $\mathrm{M}_{\mathrm{w}} 8.8$ earthquake in the Gulf of Alaska region, based on hypothetical

Case A: 4-18 km (2.5-11.2 mi) depth, uniform slip along strike ..................................................................2

Scenario 8. $\mathrm{M}_{\mathrm{w}} 8.8$ earthquake in the Gulf of Alaska region, based on hypothetical

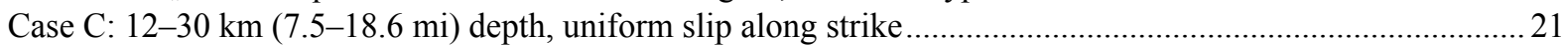

Scenario 9. $\mathrm{M}_{\mathrm{w}} 8.8$ earthquake in the Gulf of Alaska region, based on hypothetical

Case D: 4-18 km (2.5-11.2 mi) depth, variable slip along strike.................................................................2

Scenario $10 . \mathrm{M}_{\mathrm{w}} 8.8$ earthquake in the Gulf of Alaska region, based on hypothetical

Case F: $12-30 \mathrm{~km}$ ( $7.5-18.6 \mathrm{mi})$ depth, variable slip along strike ............................................................ 21

F. Tectonic Source Models of Normal Fault Earthquakes in Prince William Sound ..................................................22

G. Tectonic Source Models of Hypothetical Tohoku-type Events in the Gulf of Alaska ..........................................22

Scenario 11. $\mathrm{M}_{\mathrm{w}} 9.0$ earthquake in the Gulf of Alaska region: 4-18 km (2.5-11.2 mi) depth, uniform slip

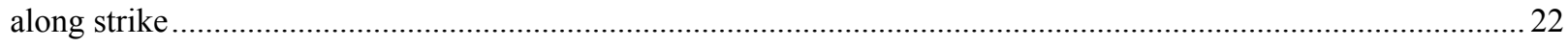

Scenario 12. $\mathrm{M}_{\mathrm{w}} 9.0$ earthquake in the Gulf of Alaska region: 4-18 km (2.5-11.2 mi) depth, variable slip



H. Tectonic Source Models of the Earthquake With Spatially Varying Depth Limits.............................................2 23

Scenario 13. $\mathrm{M}_{\mathrm{w}} 8.8$ earthquake in the Gulf of Alaska region: $12-28 \mathrm{~km}(7.5-17.4 \mathrm{mi})$ to $17-30 \mathrm{~km}$

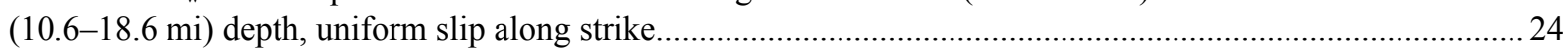

I. Tectonic Source Models of Hypothetical Tsunamigenic Earthquakes in the Yakutat Block ..................................24

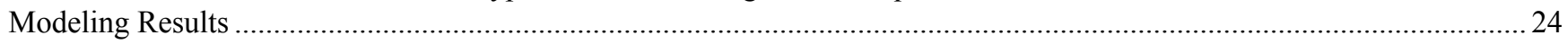

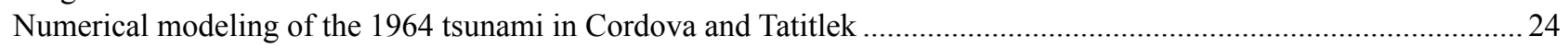

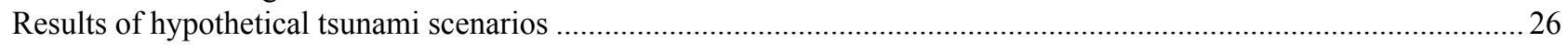

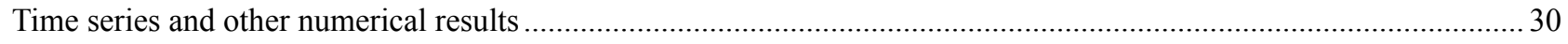



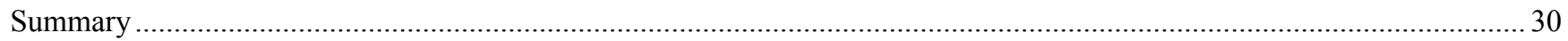

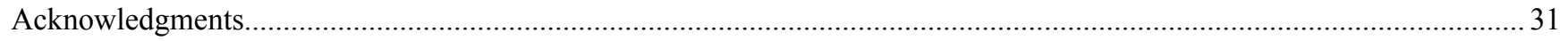

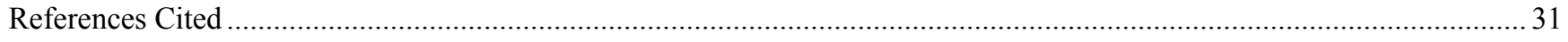




\section{FIGURES}

Figure 1. Map of south-central Alaska identifying major active or potentially active faults and the rupture zone of

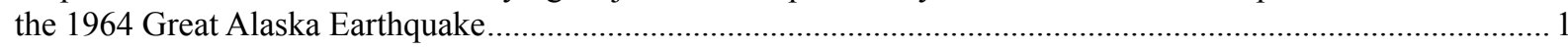

2. Topographic map of the eastern Prince William Sound region, showing the locations of Cordova and Tatitlek..... 2

3. Inferred marigram for Cordova based on accounts by eyewitnesses and inductive ............................................. 4

4. Locations of potential submarine landslides in Nelson Bay, Prince William Sound and the Gulf of Alaska,

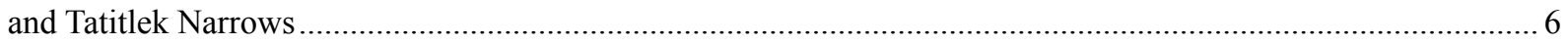

5. Nesting of the bathymetry/topography grids for numerical modeling of tsunami propagation and runup ............. 8

6. Locations of RTK GPS measurements at Cordova and Tatitlek ................................................................... 10

7. Measurement of sea level in the MHHW datum and the relation of the base station datum to the MHHW datum, and predicted water-level dynamics in Cordova and the fitted GPS measurements of the water level in the MHHW datum.

8. Map of south-central Alaska with rupture zone of the 1964 Great Alaska Earthquake and segments of the Alaska-Aleutian megathrust: the Prince William Sound (PWS), Kodiak Island (KI), and Yakataga-Yakutat (YY) segments

9. Vertical deformations of the ocean floor and adjacent coastal region, in meters, corresponding to scenarios $1-6$

10. Discretization of the plate interface model into a set of rectangles used to compute the coseismic vertical displacement by formulas developed by Okada

11. Proposed slip distribution along the plate interface for hypothetical cases $A$ through $F$ modeling a $M_{w} 8.8$

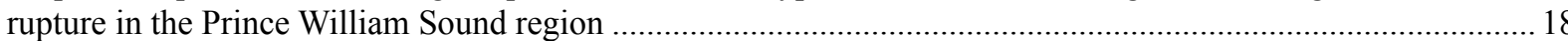

12. Computed vertical ground surface deformation related to cases $A$ through $F$ shown in figure 11 ...................... 19

13. Contour plot of the interseismic slip deficit reconstruction with contour interval of $1 \mathrm{~cm} / \mathrm{yr}(0.39 \mathrm{in} / \mathrm{yr}) \ldots \ldots \ldots \ldots . .20$

14. Proposed slip distribution along the plate interface for hypothetical Tohoku-type $M_{w} 9.0$ events in the

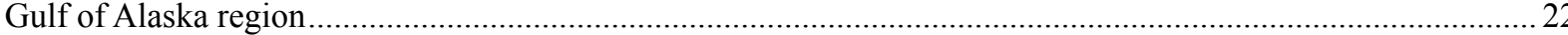

15. Computed vertical ground surface deformation related to the proposed slip distributions shown in figure 14 ..... 23

16. Modeled water level dynamics in Cordova harbor during the 1964 tsunami, based on the JDM .........................25

17. Modeled water-level dynamics in Tatitlek harbor during the 1964 tsunami .......................................................26

18. Modeled water-level dynamics in Cordova and Tatitlek according to scenarios 1 and 3 ...................................2 26

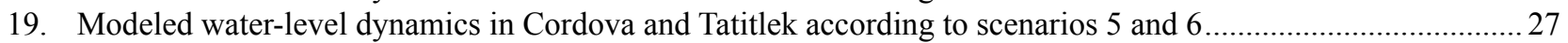

20. Modeled potential inundation in Cordova by tectonic waves for all scenarios that result in a significant inundation

21. Modeled potential inundation in Tatitlek by tectonic waves for all scenarios that result in a significant inundation

\section{TABLES}

Table 1. Nested grids used to compute propagation of tsunami waves generated in the Gulf of Alaska to the communities of Cordova and Tatitlek 9

2. All hypothetical scenarios used to model tsunami runup in Cordova and Tatitlek.............................................. 14

3. Fault parameters for the Yakataga-Yakutat (YY) segment........................................................................ 16

4. Fault parameters for normal faults in the eastern Prince William Sound region ...................................................2 21

\section{APPENDICES}

Appendix A-1. Locations of time series points in the eastern part of Prince William Sound and in the city of Cordova.... 34

A-2. Time series of water level and velocity at selected locations in Cordova for scenarios 3, 9, 10, 12 , and 13

B-1. Locations of time series points in Tatitlek Narrows and near the community of Tatitlek

B-2. Time series of water level and velocity at selected locations in Tatitlek for scenarios 3, 9, 10, 12 , and 13

C. Cordova: Maximum composite potential inundation extent from all scenarios, and maximum composite flow depths over dry land

D. Tatitlek: Maximum composite potential inundation extent from all scenarios, and maximum composite flow depths over dry land 


\title{
TSUNAMI INUNDATION MAPS OF CORDOVA AND TATITLEK, ALASKA
}

\author{
by \\ D.J. Nicolsky ${ }^{1}$, E.N. Suleimani ${ }^{1}$, and R.D. Koehler ${ }^{2}$
}

\begin{abstract}
The purpose of this study is to evaluate potential tsunami hazards for the Prince William Sound communities of Cordova and Tatitlek. We numerically model the extent of inundation from tsunami waves generated by earthquake sources and consider the results in light of historical observations. Tsunami scenarios include a repeat of the tsunami triggered by the 1964 Great Alaska Earthquake as well as tsunami waves generated by the following hypothetical scenarios: An extended 1964 rupture, a Cascadia megathrust earthquake, various earthquakes in Prince William Sound, and a Tohoku-type earthquake in the Gulf of Alaska region. Results of our numerical modeling, combined with historical observations, are designed to provide guidance to local emergency management agencies in tsunami hazard assessment, evacuation planning, and public education to mitigate damage from future tsunami hazards.
\end{abstract}

\section{INTRODUCTION}

Subduction of the Pacific plate under the North American plate has resulted in numerous great earthquakes and still has the greatest potential to generate tsunamis in Alaska. The Aleutian megathrust (fig. 1), where the Pacific plate is being subducted, is the most seismically active tsunamigenic fault zone in the U.S. Several historic tsunamis generated by earthquakes along the Alaska-Aleutian subduction zone traveled across the Pacific Ocean and impacted exposed shorelines, resulting in widespread damage and loss of life. However, tsunamis originating in the vicinity of the Alaska Peninsula,

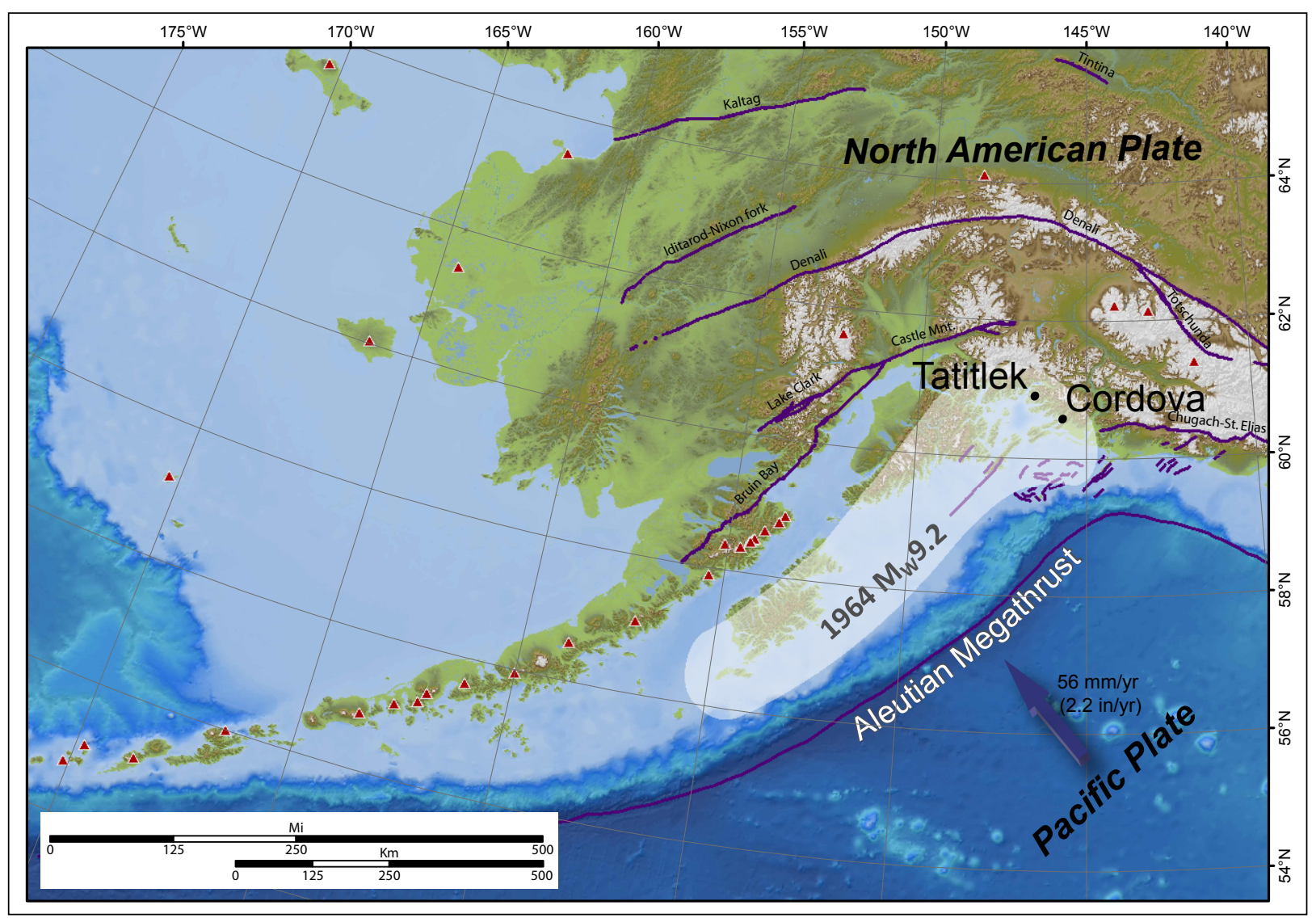

Figure 1. Map of south-central Alaska identifying major active or potentially active faults (dark purple lines) and the rupture zone of the 1964 Great Alaska Earthquake (light shaded area). Red triangles indicate historically active volcanoes.

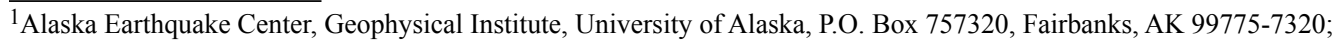
djnicolsky@alaska.edu; elena@gi.alaska.edu

${ }^{2}$ Alaska Division of Geological \& Geophysical Surveys, 3354 College Rd., Fairbanks, AK 99709-3707; richard.koehler@alaska.gov
} 
Aleutian Islands, and Gulf of Alaska are also considered to be a near-field hazard for Alaska, and can reach Alaska's coastal communities within minutes of an earthquake. Saving lives and property depends on how well a community is prepared, which further depends on understanding the potential flooding of the coastal zone in the event of a local or distant tsunami.

On March 27, 1964, the Prince William Sound area of Alaska was struck by the largest earthquake ever recorded in North America. This $\mathrm{M}_{\mathrm{w}} 9.2$ megathrust earthquake generated the most destructive tsunami in Alaska history and, farther south, impacted the west coast of the United States and Canada. In addition to the major tectonic tsunami generated by an ocean-floor displacement between the trench and coastline, numerous local tsunamis were generated by submarine landslides in coastal Alaska (Plafker and others, 1969). They arrived within minutes after shaking was felt, leaving no time for warning or evacuation. Of the 131 fatalities associated with the 1964 earthquake, 122 were caused by tsunamis (Lander, 1996). Local tsunamis caused most of the damage, and accounted for 76 percent of the total number of tsunami fatalities in Alaska.

The city of Cordova is located on the mainland of Orca Inlet, opposite Hawkins Island in the southeastern corner of
Prince William Sound (fig. 2). During the 1964 earthquake, Cordova was slightly damaged by the seismic vibration, and the tsunami ruined some coastal facilities (Wilson and Tørum, 1972). One person drowned at a small fishing camp $13.6 \mathrm{~km}$ ( $8.5 \mathrm{mi}$ ) southwest of Cordova (Plafker and others, 1969). The village of Tatitlek is about $64 \mathrm{~km}$ (40 mi) northwest of Cordova, in the area of Prince William Sound between Valdez Arm and Port Fidalgo (fig. 2). During the 1964 earthquake, the shaking at Tatitlek was severe, but no structural damage was reported from the earthquake or tsunami. Even though the 1964 tsunami caused only limited damage to Cordova and Tatitlek, both locations are considered to be vulnerable to future tsunamis. Therefore the potential occurrence of damaging tsunami waves must be evaluated, for the development of inundation mapping products and for the establishment of tsunami evacuation procedures.

The production of tsunami evacuation maps for a community is completed in several stages. First, we develop hypothetical tsunami scenarios on the basis of credible potential tsunamigenic earthquakes and submarine landslides, if credible landslide scenarios exist. Next, we perform model simulations for each of these scenarios. The results are compared with any historical tsunami observations, if such data exist. Finally, we develop a "worst-case" inundation line

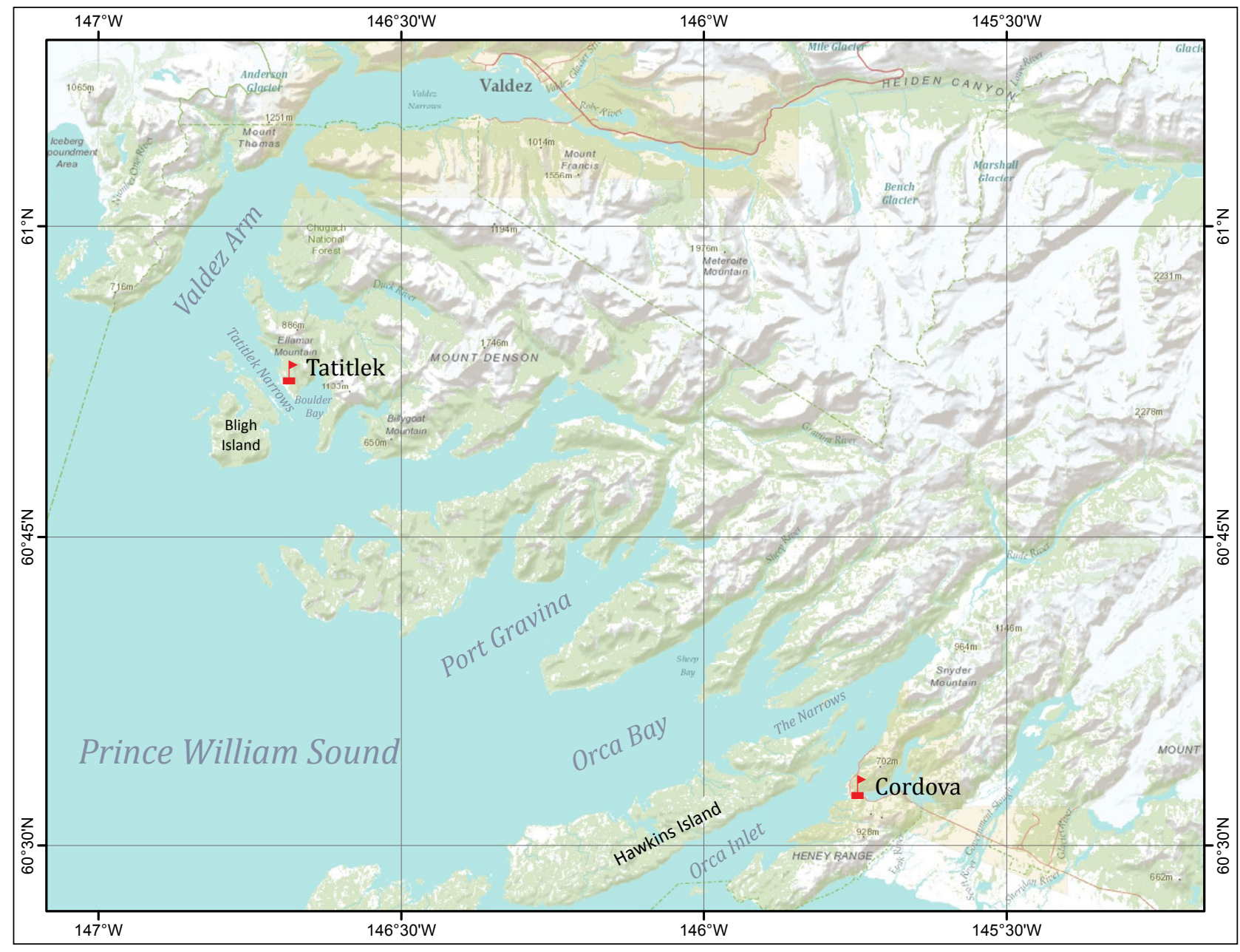

Figure 2. Topographic map of the eastern Prince William Sound region, showing the locations of Cordova and Tatitlek. 
that encompasses the maximum extent of flooding based on model simulation of all source scenarios and available historical observations. The "worst-case" inundation line becomes a basis for local tsunami hazard planning and development of evacuation maps.

The tsunami inundation maps of Cordova and Tatitlek described in this report represent the results of continuous efforts between state and federal agencies to produce inundation maps for many of Alaska's coastal communities. In this report, we generally provide both metric and imperial units of measure. Where we quote existing data, we report the data in the original units without conversion. To convert kilometers to miles, multiply by 0.6214 .

\section{PROJECT BACKGROUND: REGIONAL AND HISTORICAL CONTEXT}

\section{Setting}

The city of Cordova was founded on March 26, 1906, near the Alaska Native village of Eyak, at the base of Mount Eyak $\left(60^{\circ} 32^{\prime} \mathrm{N}, 145^{\circ} 45^{\prime} \mathrm{W}\right)$. The city is about $83 \mathrm{~km}(52 \mathrm{mi})$ southeast of Valdez and $240 \mathrm{~km}(150 \mathrm{mi})$ southeast of Anchorage. In its early days, Cordova was a terminus for the Copper River and Northwestern Railroad leading from the tidewater to rich copper deposits in the Chitina-Kennecott region. In the first half of the 20th century, more than 590,000 tons of copper and about 9 million ounces of silver from Kennecott were shipped through the community (Douglass, 1964). Today Cordova is a fishing and canning center for the Prince William Sound region. The Cordova harbor is a port for the Alaska Marine Highway System and has ferry service year round. According to the 2010 census, the city population is 2,289, with 393 residents holding commercial fishing permits. The fishing industry is still struggling to recover from the devastating effects of the Exxon-Valdez oil spill in Prince William Sound not far from Tatitlek.

Tatitlek, located near an abandoned copper mine at Ellamar Mountain $\left(60^{\circ} 52^{\prime} \mathrm{N}, 146^{\circ} 41^{\prime} \mathrm{W}\right)$, is a coastal Alutiiq village with a population of 88 . In 1964 there were no roads or airports in Tatitlek, but the village has since developed considerably. Tatitlek has a state-owned $1.1 \mathrm{~km}(0.7 \mathrm{mi})$ lighted gravel airstrip and a seaplane landing area; however, boats are the primary means of local transportation. The Alaska Marine Highway provides regular service to Tatitlek from Valdez and Cordova. As in Cordova, much of the economic activity and infrastructure in Tatitlek is located on or near the coast and harbors, both potential inundation areas.

\section{Tsunami Waves at Cordova, Alaska, on March 27, 1964}

Cordova is connected to the Gulf of Alaska and Prince William Sound by a series of shallow waterways. Maps in Wilson and Tørum (1972) of the pre-earthquake bathymetry around Hawkins Island show that most of Orca Inlet was shallower than $6 \mathrm{~m}(20 \mathrm{ft})$. During the earthquake the town was uplifted by about $1.8 \mathrm{~m}(6 \mathrm{ft})$, and extensive dredging was needed to restore access routes through the shoal region in Orca Inlet. Presently, some parts of Orca Inlet south of
Cordova are shallower than 4-5 m (13-16 ft) and can be exposed during a low tide.

The 1964 earthquake in Cordova lasted for three to five minutes (Plafker and others, 1969). The shaking was strong, but people had no difficulty standing. Eyewitnesses at the Federal Aviation Administration (FAA) facility, on the Copper River Delta, reported much more violent shaking, and airport facilities were damaged by ground surface waves and by numerous ground fissures that opened and closed during the earthquake (Plafker and others, 1969). All bridges built on the unconsolidated deposits between the airport and the city of Cordova were severely damaged. One bridge over the Eyak River, constructed on bedrock, escaped damage.

Despite widespread earthquake-induced damage to the infrastructure outside of Cordova, the tsunami caused most of the damage to the city itself. The uplift of Orca Inlet caused water to drain from the harbor area. The initial withdrawal was gradual, with some periodic (15-20 minutes) gentle fluctuations in water level. A reconstructed sequence of waves was completed by Wilson and Tørum (1972) from eyewitness reports and observations and is shown in figure 3 . We emphasize that the tsunami occurred in the evening and at night, so visibility was poor and there are resulting uncertainties in the estimated wave heights and in the timing of events. According to Harbormaster William L. Phillips there were six waves, beginning at 7:00 pm, with the highest arriving at about 1:15 am, March 28 (Chance, 1972). The highest wave nearly coincided with the highest tide and was "rapidly, but quietly, rising as much as $0.5-1 \mathrm{ft} /$ second, to a level about 3 $\mathrm{ft}$ over the dock, or about $20 \mathrm{ft}$ above original Mean Lower Low Water (MLLW)." Furthermore, according to Phillips, this wave flooded up to $300 \mathrm{ft}$ inland, causing extensive damage to waterfront buildings. The high water of the sixth wave began to withdraw at about 1:45 am.

According to other observers, a high wave struck Cordova between 11:37 pm and 11:45 pm. McMahon gave its

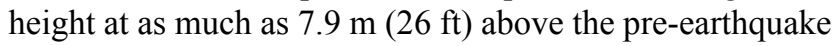
MLLW at 11:37 pm, while Orlowski reported $4.0 \mathrm{~m}(13 \mathrm{ft})$ above the apparent MLLW (Wilson and Tørum, 1972). This was probably the highest reported wave to strike Cordova.

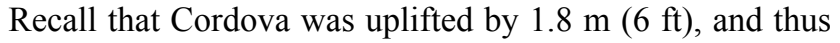
the highest reported wave could have been about $9.8 \mathrm{~m} \mathrm{(32}$ $\mathrm{ft}$ ) above the post-earthquake MLLW. It seems peculiar that this wave was reported neither by the Harbormaster nor by a captain of the Coast Guard ship Sedge, which was docked in the Cordova harbor at the time.

Finally, it is noteworthy that during and immediately after the earthquake, no strange waves were observed in the harbor and that the highest wave in Cordova coincided with the high tide about 6 hours after the earthquake. The tectonic uplift was considered to be more disastrous than the tsunami because all Cordova port facilities were raised so that boats could not reach them except at high tide. The cost of damage to Cordova from wave action was estimated to be $\$ 1,775,000$ (Wilson and Tørum, 1972), while the cost of dredging and the cost of repairs to the sewer system added up to $\$ 3,000,000$ (Plafker and others, 1969). 


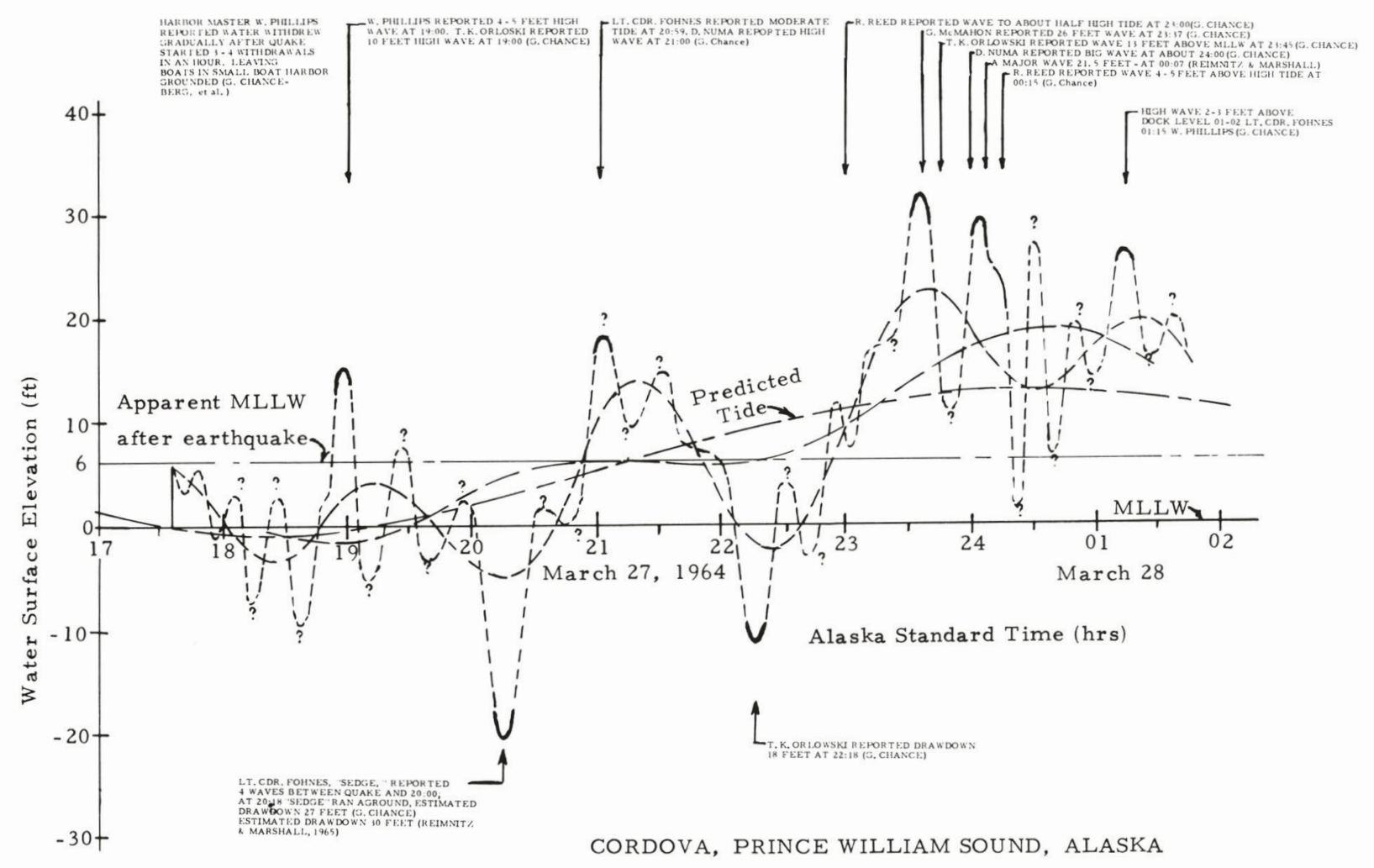

Figure 3. Inferred marigram f or Cordova based on accounts by eyewitnesses and inductive reasoning (Wilson and Tørum, 1972).

\section{Tsunami Waves in Tatitlek Narrows, Alaska, on March 27, 1964}

The following account of the tsunami waves at Tatitlek is taken from Plafker and others (1969) unless otherwise noted. At Tatitlek, the 1964 earthquake was characterized by strong vibration lasting 3.5 to 5 minutes. According to residents of Tatitlek, the church bell rang during the earthquake and standing was difficult or impossible. However, there was no structural damage in the village. Water in the ocean withdrew "immediately" during the earthquake and then came back up to $5.2-5.5 \mathrm{~m}(17-18 \mathrm{ft})$ above the normal MLLW level, but did not reach above the extreme high tide line, which was uplifted by about $1.2-1.5 \mathrm{~m}$ (3.9-4.9 ft). A similar account is provided by Wilson and Tørum (1972), who state that the water receded by $4.6 \mathrm{~m}(15 \mathrm{ft})$ and then returned to $5.2-5.5 \mathrm{~m}$ (17-18 ft) above the MLLW. Additionally, Wilson and Tørum (1972) state that at 9:00 pm a high wave rose to within $0.2 \mathrm{~m}$

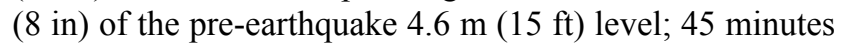
later, there was a wave with a height of $1.6 \mathrm{~m}(5.2 \mathrm{ft})$ above the normal tide of that time (Chance, 1972).

Unlike residents of Valdez and Cordova, who observed high waves late in the evening, Tatitlek residents noticed no "strange" waves in the narrows. Some erratic tides were observed, but none of them reached above the extreme hightide line, and the wave action during the tectonic tsunami did not cause any damage. Since the tectonic uplift near Tatitlek Narrows during the 1964 event was approximately $1.4 \mathrm{~m}$ (4.6 ft), the local harbor suffered from the loss of mooring depth. Following the earthquake, the harbor restoration project in Tatitlek was awarded approximately $\$ 70,000$ in 1964 dollars $^{3}$.

\section{Landslide-Generated Tsunami Hazards in Cordova and Tatitlek}

Kulikov and others (1998) analyzed tsunami catalog data for the north Pacific coast and show that south-central and southeastern Alaska have long recorded histories of tsunamis generated by submarine and subaerial landslides, avalanches, and rockfalls. In the majority of cases, tectonic tsunamis arriving in bays and fjords from the open ocean had wave heights smaller than those of local, landslide-generated tsunamis. For example, the 1964 landslide-generated tsunami in Port Valdez devastated the waterfront and caused a $52 \mathrm{~m}$ $(170 \mathrm{ft})$ runup near Shoup Bay, while the tectonic tsunami was not even noticed until a high tide late in the evening (Coulter and Migliaccio, 1966).

A primary cause of submarine slumps or landslides is the accumulation of sediments on underwater slopes and the consequent over-steepening of unconsolidated deposits. Typical locations of unstable sediment accumulations are on steep underwater slopes at the mouths of glacier-fed rivers, creeks, and streams. The shallow bathymetry of Orca Inlet and Tatitlek Narrows, along with the absence of large glacial creeks near either community, suggests that the potential for

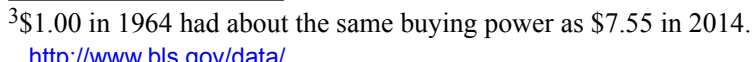


submarine landslide-generated tsunamis near the Cordova waterfront and Tatitlek harbor is low.

The closest possible submarine landslide source to Cordova is the delta of the Rude River at the head of Nelson Bay (Peter Haeussler, U.S. Geological Survey [USGS], oral commun., 2012); however, little is known about its potential volume and geometry. In figure $4 \mathrm{a}$, we show the location of this hypothetical submarine slide and its possible direction of propagation. The water body connecting Nelson Bay to the city of Cordova is rather shallow, from which we speculate that most of the wave energy would be directed through the deep channel (the Narrows) toward Orca Bay. However, some dissipated waves might reach Cordova.

Finn (2012) identified several late Holocene and modern submarine landslides along the northwestern side of Hawkins Island (southern Orca Bay) and showed prominent slides on bathymetric data (Finn, 2012, fig. 55). The region with the identified slide remnants is approximately outlined in figure $4 \mathrm{~b}$ and marked by letter A. Although no information is provided on the volume of the slides, we used the bathymetric maps that show the slides (fig. 32 in Finn, 2012) to estimate that the easternmost slide is approximately $3 \mathrm{~km}(1.9 \mathrm{mi})$ long and $2 \mathrm{~km}(1.2 \mathrm{mi})$ wide. We speculate that initial wave energy from similar future landslides in this area will be directed toward the north, and that the landmass of Hawkins Island and shallow bathymetry of Orca Inlet will serve to protect Cordova from the ensuing waves. We postulate further that the landmass along the northern side of Port Gravina may protect the community of Tatitlek from submarine-landslidegenerated waves originating from the margin of Hawkins Island. Additional constraints on the depth and volume of the slide are necessary before tsunami modeling efforts can be performed. Thus, although these slides are a potential hazard, this report does not assess the potential inundation from associated waves.

Other potential locations for submarine slump failures (fig. 4b) are noted in the center of Prince William Sound and on the continental shelf (Peter Haeussler, USGS, oral commun., 2012). Unfortunately, little is known about the extent, volume, and locations of these potential landslides. Some numerical simulations of these landslide-generated tsunamis are possible; however, these simulations require more scientific research to further constrain their locations and volumes before value-added results can be generated. Finally, we note that energy from a submarine landslide along the continental slope would likely be dissipated during its propagation over the shallow regions offshore of Hinchinbrook Island and in the shallows of Orca Inlet.

The destructive effects of mass-movement-generated tsunamis have been identified previously in south-central and southeastern Alaska. The best known and largest subaerial mass-movement-generated tsunami of historic time took place in Lituya Bay, Alaska, on June 9, 1958, when a magnitude 7.9 earthquake occurred on the nearby Fairweather fault and produced an estimated 30 million $\mathrm{m}^{3}$ (1,050 million $\mathrm{ft}^{3}$ ) rockfall that rapidly entered the water and initiated a tsunami with the highest wave ever recorded (524 $\mathrm{m}[1,700 \mathrm{ft}]$ ) (Miller, 1960).
In light of recent field observations in a steep-walled glacial fjord, we appended the tsunami modeling and mapping report for the city of Whittier and Western Passage Canal with an additional hypothetical rockfall-generated tsunami scenario (Nicolsky and others, 2011b, 2011c). Likewise, steep mountain slopes are present near Cordova, the southern side of Hawkins Island, and Hinchinbrook Island as well as near Tatitlek, specifically the southeastern flank of Ellamar Mountain. Thus, the threat of avalanches, debris flows, and rock falls plunging into the ocean and consequently generating a tsunami exists at the both communities. Our ability to accurately model effects of a potential rapid subaerial mass failure and the subsequent impact of the rockfall/landslide/avalanche-generated tsunami on the community depends on our knowledge of the type and geometry of the mass movement, local bedrock geology, and location. Unfortunately, dense vegetation covers the slopes on which the potential mass failures may be located; as a result, the location and geometry of the potential mass failures threatening Cordova and Tatitlek are currently unknown. Although some numerical simulations of the rockfall/landslide/avalanchegenerated tsunamis are possible, more scientific research is necessary to constrain the landslide sources before meaningful results can be generated.

In this report, we do not model tsunamis generated by any mass failures due to insufficient data on the locations and volumes of these potential hazards ${ }^{4}$.

\section{Tsunami Hazards Due to Large Horizontal Displacements}

Seiche tsunamis, caused by abrupt horizontal tectonic displacements, present an additional hazard in glacial fjords and steep-sided basins. The rapid lateral motion of land relative to the body of water may result in significant local water disturbances during or immediately after the earthquake.

Plafker and others (1969) conducted geologic investigations after the 1964 earthquake in numerous locations around south-central and southeastern Alaska. According to the retriangulation data, the southward land displacement increases

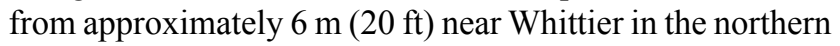
part of the sound to as much as $18 \mathrm{~m}(60 \mathrm{ft})$ near Evans and Latouche islands in the south. Plafker and others (1969) concluded that a primary cause of local waves of "unknown origin" that devastated communities and uninhabited shores around Prince William Sound was a fast horizontal displacement. It was also inferred by Plafker and others (1969) that the major factors contributing to the formation of seiche tsunamis are the magnitude of the tectonic displacement combined with the orientation and configuration of the shoreline.

Because no strange waves were observed at Cordova during the 1964 event, and because the wave at Tatitlek did not flood beyond the high tide level, we speculate that the shallow bathymetry of Tatitlek Narrows (shown in fig. 4c) and Orca Inlet (shown in fig. 4a) minimize the seiche hazard near both of these communities. Therefore, this type of hazard is not considered in this report.

\footnotetext{
${ }^{4}$ Guidelines and best practices for tsunami inundation modeling for evacuation planning state that the modeling should add value to mapping products (National Tsunami Hazard Mapping Program [NTHMP], 2010).
} 


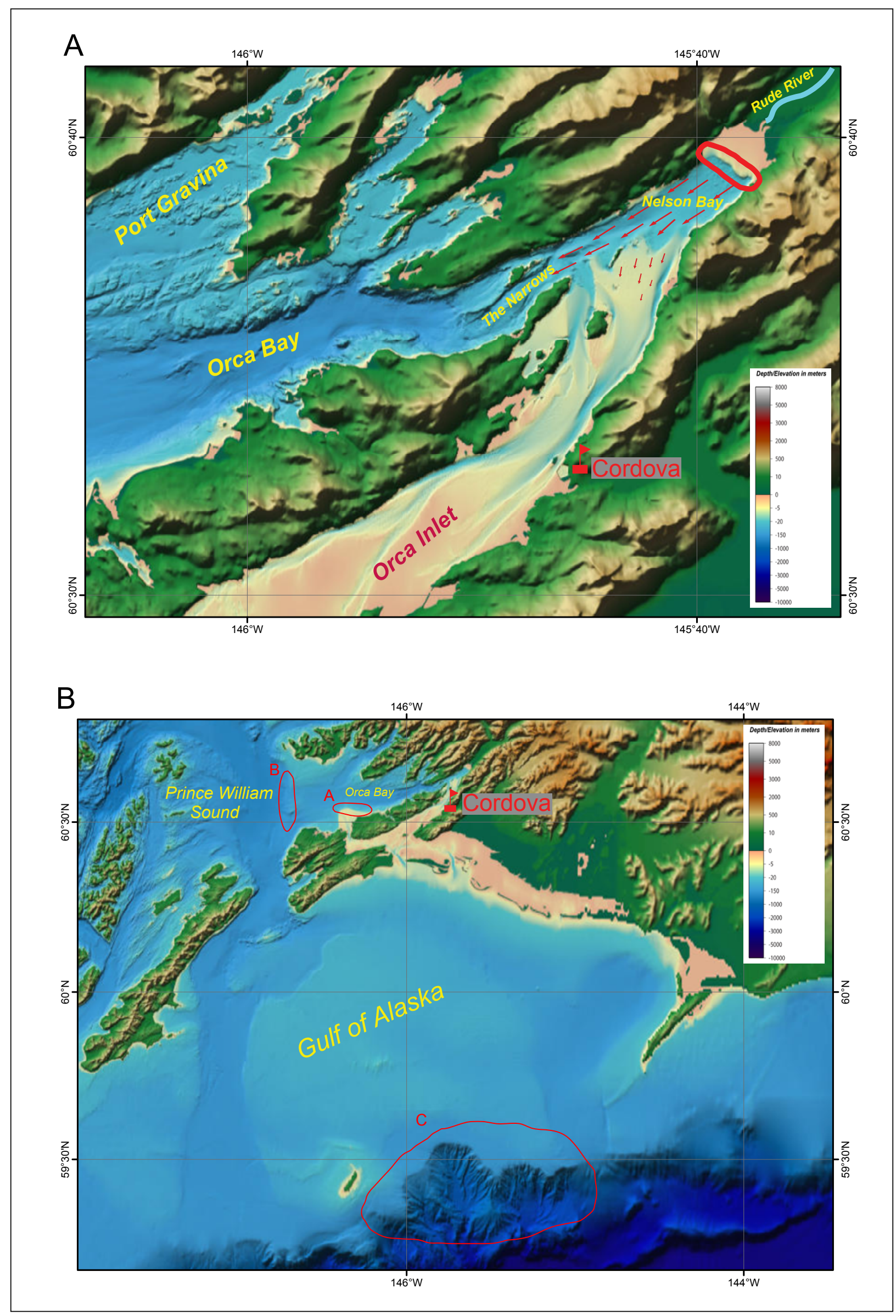

Figure 4. Bathymetry; locations of potential submarine landslides in (A) Nelson Bay, (B) Prince William Sound and the Gulf of Alaska, and (C) Tatitlek Narrows. 


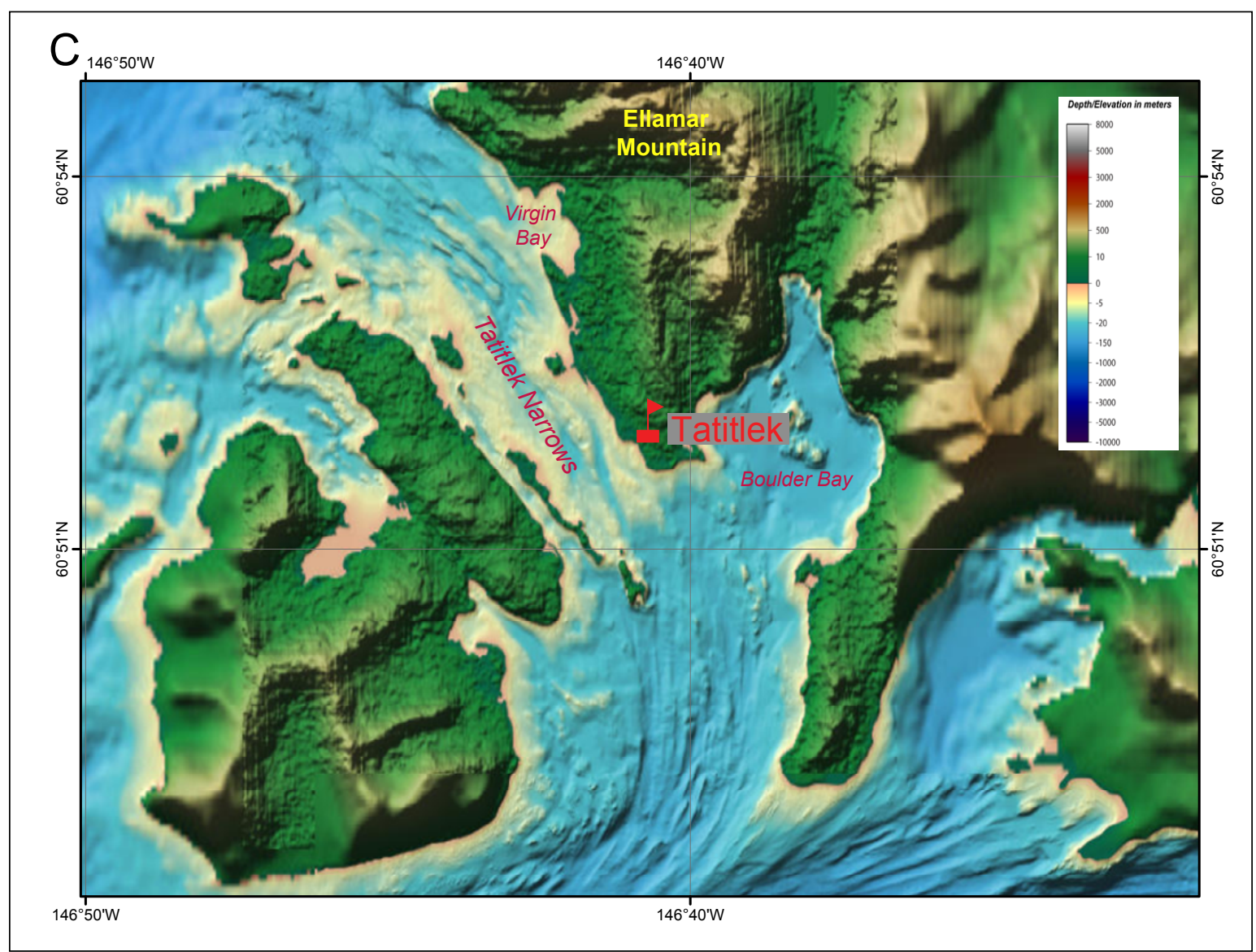

Figure 4 (cont). Locations of potential submarine landslides in (A) Nelson Bay, (B) Prince William Sound and the Gulf of Alaska, and (C) Tatitlek Narrows.

\section{METHODOLOGY AND DATA}

\section{Grid Development and Data Sources}

One of the challenges in tsunami modeling is that the governing equations for water dynamics are continuous. In this work, we discretize the shallow-water equations in spherical coordinates on the Arakawa C-grid using a finite difference method. To resolve a wave, the grid must be fine enough, with at least four points per wavelength (Titov and Synolakis, 1995); however, more points than that are often necessary to achieve satisfactory accuracy (for example, Titov and Synolakis, 1997). To compute a detailed map of potential tsunami inundation triggered by local and distant earthquakes, we employ a series of nested computational grids. A nested grid allows for higher resolution in areas where it is needed without expending computer resources in areas where it is not. The bathymetric and topographic relief in each nested grid is based on digital elevation models (DEMs) developed at the National Geophysical Data Center (NGDC), National Oceanic \& Atmospheric Administration (NOAA), in Boulder, Colorado. The extent of each grid used for the Cordova and Tatitlek mapping is shown in figure 5 and listed in table 1 . The coarsest grid, with 2-arc-minute (approximately $2 \mathrm{~km}$ ) resolution, spans the central and northern Pacific Ocean. The highest resolution grid for Cordova covers Orca Inlet, including Nelson Bay and a part of Simpson Bay.
The highest-resolution grid for Tatitlek covers Tatitlek Narrows, including parts of Boulder Bay and Virgin Bay. The spatial resolution of the high-resolution grid cells, with about $13 \times 16 \mathrm{~m}(43 \times 52 \mathrm{ft})$ dimensions, satisfies NOAA minimum recommended requirements for computation of tsunami inundation (National Tsunami Hazard Mapping Program [NTHMP], 2010).

The bathymetric data for the 2-arc-minute-resolution grid is extracted from the ETOPO2 data set (NGDC/NOAA). To develop 8/3-, 8- and 24-arc-second-resolution grids, shoreline, bathymetric, and topographic digital datasets were obtained from the following U.S. federal and academic agencies: NOAA's National Ocean Service (NOS), Office of Coast Survey, and National Geophysical Data Center (NGDC); the U.S. Fish \& Wildlife Service (FWS); the U.S. Geological Survey (USGS); and the U.S. Army Corps of Engineers (USACE). All data were shifted to World Geodetic System 1984 (WGS 84) horizontal and Mean Higher High Water (MHHW) vertical datums. The FWS statewide Alaska digital coastline was employed to create a coastline of the Prince William Sound region. Bathymetric datasets used in the compilation of the Prince William Sound DEMs included NOS hydrographic surveys, a recent USACE harbor survey, NOAA Electronic Navigational Charts, multi-beam swath sonar surveys, and NGDC trackline surveys. Topographic 




Figure 5. Nesting of the bathymetry/topography grids for numerical modeling of tsunami propagation and runup. The coarsest grid, Level 0, covers the central and northern Pacific Ocean. Location of each embedded grid is marked by a red rectangle. A map of the high-resolution grid, Level 4, is not shown because this grid does not nest any other grids. The red semitransparent rectangles mark areas of the grid refinement. 
Table 1. Nested grids used to compute propagation of tsunami waves generated in the Gulf of Alaska to the communities of Cordova and Tatitlek. The high-resolution grids are used to compute the inundation. Note that the grid resolution in meters is not uniform and is used to illustrate grid fineness in the Prince William Sound region. The first dimension is the longitudinal grid resolution, while the second is the latitudinal resolution.

\begin{tabular}{|c|c|c|c|c|}
\hline \multirow{2}{*}{ Grid name } & \multicolumn{2}{|c|}{ Resolution } & \multirow{2}{*}{$\begin{array}{l}\text { West-East } \\
\text { boundaries }\end{array}$} & \multirow{2}{*}{$\begin{array}{l}\text { South-North } \\
\text { boundaries }\end{array}$} \\
\hline & arc-seconds & meters (in PWS) & & \\
\hline Level 0, Northern Pacific & $120 \times 120$ & $\approx 1,850 \times 3,700$ & $120^{\circ} 00^{\prime} \mathrm{E}-100^{\circ} 00^{\prime} \mathrm{W}$ & $10^{\circ} 00^{\prime} \mathrm{N}-65^{\circ} 00^{\prime} \mathrm{N}$ \\
\hline Level 1, Kodiak-Kenai & $24 \times 24$ & $\approx 370 \times 740$ & $145^{\circ} 00^{\prime} \mathrm{W}-156^{\circ} 00^{\prime} \mathrm{W}$ & $55^{\circ} 00^{\prime} \mathrm{N}-62^{\circ} 00^{\prime} \mathrm{N}$ \\
\hline Level 2, Coarse Prince William Sound & $8 \times 8$ & $\approx 120 \times 250$ & $145^{\circ} 00^{\prime} \mathrm{W}-150^{\circ} 00^{\prime} \mathrm{W}$ & $58^{\circ} 30^{\prime} \mathrm{N}-61^{\circ} 30^{\prime} \mathrm{N}$ \\
\hline Level 3, Fine Prince William Sound & $8 / 3 \times 8 / 3$ & $\approx 40 \times 82$ & $145^{\circ} 20^{\prime} \mathrm{W}-148^{\circ} 46^{\prime} \mathrm{W}$ & $59^{\circ} 40^{\prime} \mathrm{N}-61^{\circ} 20^{\prime} \mathrm{N}$ \\
\hline Level 4, High-resolution Cordova & $8 / 9 \times 8 / 15$ & $\approx 13 \times 16$ & $145^{\circ} 30^{\prime} \mathrm{W}-145^{\circ} 54^{\prime} \mathrm{W}$ & $60^{\circ} 30^{\prime} \mathrm{N}-60^{\circ} 43^{\prime} \mathrm{N}$ \\
\hline Level 4, High-resolution Tatitlek & $8 / 9 \times 8 / 15$ & $\approx 13 \times 16$ & $146^{\circ} 44^{\prime} \mathrm{W}-146^{\circ} 39^{\prime} \mathrm{W}$ & $60^{\circ} 54^{\prime} \mathrm{N}-60^{\circ} 51^{\prime} \mathrm{N}$ \\
\hline
\end{tabular}

datasets of Prince William Sound were obtained from the USGS National Elevation Dataset 2-arc-second gridded topography and 1-arc-second NASA Space Shuttle Radar Topography. The data sources and methodology used to develop high-resolution, 8/3-, 8-, and 24-arc-second DEMs are described in detail by Caldwell and others (2009) and Lim and others (2009).

Accuracy of the high-resolution DEM developed by NOAA is determined by the topographic datasets with vertical accuracy of 10-15 meters (Caldwell and others, 2009). Because the DEM can possess large vertical errors near the shoreline, prediction of the potential tsunami inundation can be invalid. Hence, the topographic datasets are augmented with some high-accuracy data, such as a real-time kinematic (RTK) GPS survey in the harbor areas and along near-shore areas in Cordova and Tatitlek. The survey in Cordova was conducted April 16-17, 2010, while the survey in Tatitlek was completed September 25-26, 2010. Locations of the GPS measurements in Cordova and Tatitlek are shown in figures $6 \mathrm{a}$ and $6 \mathrm{~b}$. The collected GPS measurements had 0.03-0.05 $\mathrm{m}(1.2-2$ in) lateral and vertical accuracy with respect to the base station (Leica Geosystem AG, 2002). Therefore, to achieve sub-meter accuracy of all GPS measurements related to the MHHW datum, the base station datum must be known with respect to the MHHW datum with sub-meter accuracy. Such base station accuracy can be achieved if the base station is set up at a well known benchmark or monument. We could not find a conveniently located benchmark in Cordova and Tatitlek during the survey, so we used the technique described below to convert the collected GPS measurements into the MHHW datum.

During the survey, we took GPS measurements of the sea surface height at some partially enclosed locations where the water was relatively still (for example, in the harbor), as shown by the red arrow in figure $7 \mathrm{a}$. The sea level was measured at low and high tides as well as at some intermediate tide stages. Recall that all RTK GPS measurements have an accuracy of several centimeters relative to the base station datum. Therefore, the measured tide level, denoted by $\mathrm{H}_{2}$, is known relative to the base station datum at some instance of time, $t_{\mathrm{k}}$, with an accuracy of several centimeters. Here, $\mathrm{k}$ stands for the $k-t h$ measurement of the sea level.

The tide level, $\mathrm{H}_{1}(\mathrm{t})$, with respect to the MHHW datum is observed every 6 minutes at the NOAA tide stations in Cordova and Valdez. Since Tatitlek and Valdez are close to each other and are connected by deep water, we assume that the MHHW datums in both locations coincide and that observations in Valdez provide a good approximation to the tide level dynamics in Tatitlek. Therefore, we calculate the vertical shift between the MHHW datum and the base station datum by finding a difference (in the least square) between the GPS-measured sea level, $\mathrm{H}_{2}$, and the NOAA-observed sea level, $\mathrm{H}_{1}$, at the instances $t_{\mathrm{k}}$. The results of the least square fitting for Cordova are shown in figure $7 \mathrm{~b}$. Once the vertical shift is calculated, we apply the same shift to all collected GPS measurements and convert the entire survey to the MHHW datum.

We check the accuracy of our conversion of the GPS data to the MHHW level by estimating the height of the tidal station disk ' 4050 H 1982' in Cordova. According to the NOAA website (http://tidesandcurrents.noaa.gov/), the disk is $5.685 \mathrm{~m}(18.65 \mathrm{ft})$ above the MHW, or $5.405 \mathrm{~m}$ $(17.73 \mathrm{ft}$ ) above the MHHW. After measuring the height of this disk during the GPS survey and converting to the MHHW datum, we estimate that the disk is $5.470 \mathrm{~m}(17.95 \mathrm{ft})$ above the MHHW. The difference of $0.07 \mathrm{~m}(0.23 \mathrm{ft})$ between the NOAA stamping and our estimates demonstrates that the conversion of the GPS measurements to the MHHW level provides a sub-meter accuracy in Cordova. Because we could not locate any tidal station disks in Tatitlek, we hypothesize that a similar accuracy of conversion is achieved for the survey in Tatitlek. Finally, we note that the collected GPS measurements have the WGS84 horizontal datum, with a horizontal accuracy of approximately $3-5 \mathrm{~m}(10-16 \mathrm{ft}$ ) (Leica Geosystem AG, 2002). The converted GPS survey has been provided to the NGDC, where the high-resolution DEM of Tatitlek and adjacent areas has been developed. Incorporation of the GPS measurements in the DEM covering Cordova and Orca Inlet is completed using the Matlab software locally at the Geophysical Institute, University of Alaska Fairbanks. 


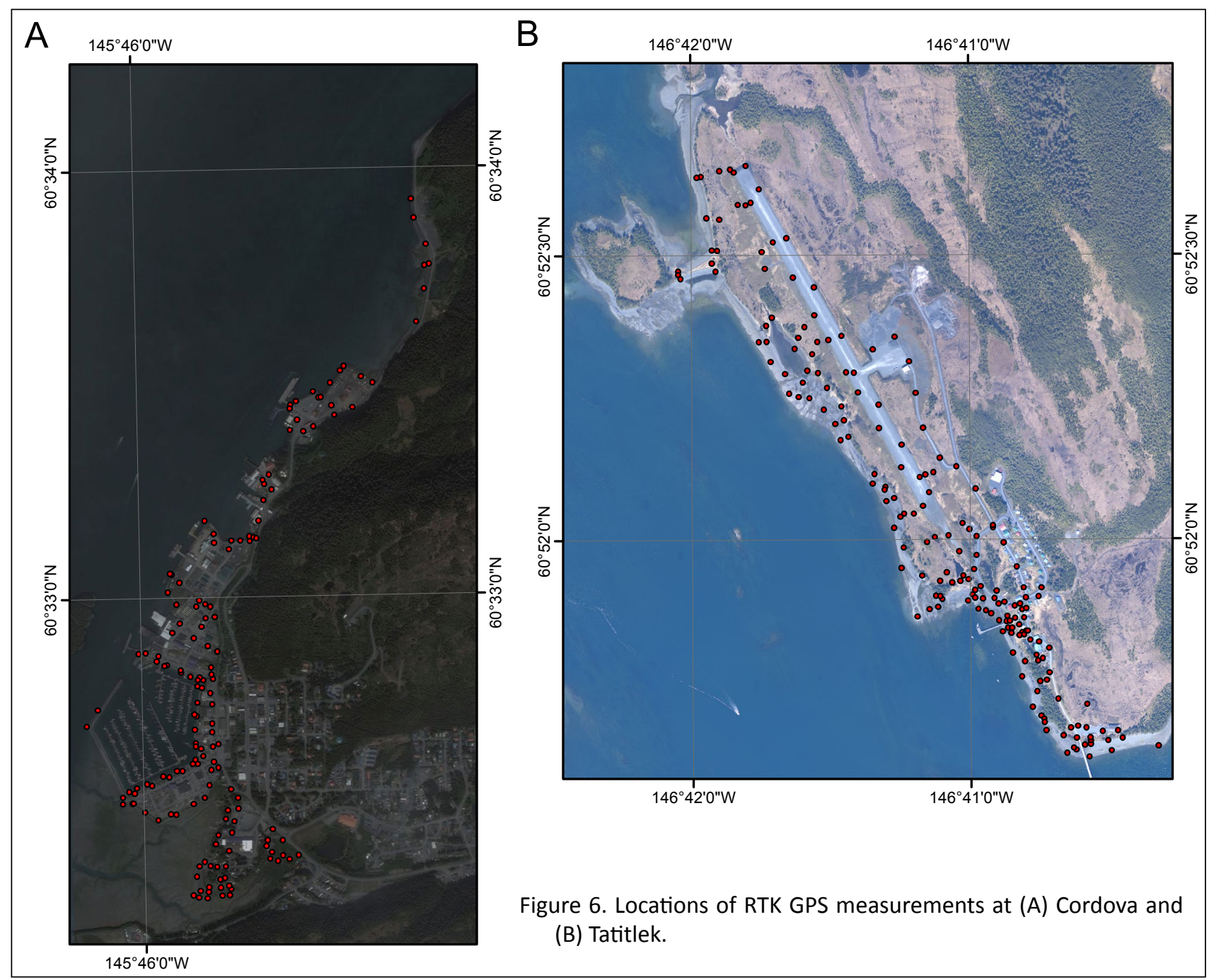

\section{Numerical Model of Tsunami Propagation and Runup}

NOAA recently published a technical memorandum that outlines major requirements for numerical models used for inundation mapping and tsunami forecasting and describes a procedure for model evaluation (Synolakis and others, 2007; NTHMP, 2012). There are two major components to this process. The first is model validation, which ensures that the model correctly solves appropriate equations of motion by comparing model results with known solutions. This is achieved through analytical and laboratory benchmarking. The second component is model verification, or testing the model, using observations of real events through field data benchmarking.

The numerical model currently used by the Alaska Earthquake Center (AEC) for tsunami inundation mapping has been validated through a set of analytical benchmarks and tested against laboratory and field data (Nicolsky and others, 2011a; Nicolsky, 2012). The model solves nonlinear shallow-water equations using a finite-difference method on a staggered grid. For any coarse-fine pair of computational grids, we apply a time-explicit numerical scheme as follows. First, we compute the water flux within a coarse-resolution grid. These calculated flux values are used to define the water flux on a boundary of the fine-resolution grid. Next, the water level and then the water flux are calculated over the fine-resolution grid. Finally, the water level computed in the fine-resolution grid is used to define the water level within the area of the coarse-resolution grid that coincides with the fine grid. Consecutively, we compute the water elevation for all other points in the coarse grid and proceed to the next time step. More details about the numerical scheme, grid nesting, and time stepping can be found in Goto and others (1997) and in Nicolsky and others (2011a). Even though the nested grids decrease the total number of grid cells needed to preserve computational accuracy within certain regions of interest, actual simulations are still unrealistic if parallel computing is not implemented. Here, we use the Portable Extensible Toolkit for Scientific computation (PETSc), which provides sets of tools for the parallel numerical solution of shallowwater equations (Balay and others, 2012). In particular, each computational grid listed in table 1 can be subdivided among an arbitrary number of processors. The above-mentioned passing of information between the water flux and level is implemented efficiently using PETSc subroutines. 
We assess hazards related to tectonic tsunamis in Cordova and Tatitlek by performing model simulations for each hypothetical earthquake source scenario. To simulate tsunami dynamics caused by a seafloor deformation due to an earthquake, we assume some simplifications. First, an initial displacement of the ocean surface is equal to the vertical displacement of the ocean floor induced by the earthquake rupture process. Second, the finite speed of the rupture propagation along the fault is not taken into account. We consider the ocean bottom displacement to be instantaneous. Third, the initial topography is modified to account for coseismic deformation of land due to the earthquake.

At the end of a tsunami simulation, each of the grid points has either a value of 0 if no inundation occurs or 1 if seawater reaches the grid point at any time. The inundation line lies halfway between grid points with values of 0 and 1 , but was adjusted visually to accommodate obstacles or local variations in topography not represented by the DEM. Although the developed algorithm has passed through rigorous benchmarking procedures (Nicolsky and others, 2011a; Nicolsky, 2012), there is still uncertainty in locating an inundation line. The accuracy is affected by many factors on which the model depends, including suitability of the earthquake source model, accuracy of the bathymetric and topographic data, and the adequacy of the numerical model in representing the generation, propagation, and runup of tsunamis. In this report, we do not attempt to adjust the modeled inundation limits to account for these uncertainties.

One important limitation of the model is that it does not account for the periodic change of sea level due to tides. With the exception of numerical modeling of the 1964 tsunami for model validation, we conducted all model runs using bathymetric data that correspond to the MHHW tide level in Cordova and Tatitlek.

\section{TSUNAMI SOURCES}

The 1964 Great Alaska Earthquake ruptured a region from Prince William Sound to Kodiak Island and generated one of the most destructive tectonic tsunamis in Alaskan history. Therefore, we consider a repeat of the 1964 earthquake and tsunami as a potential worst-case scenario for Cordova and Tatitlek. Before discussing this earthquake, as well as other credible scenarios for potential tsunamigenic earthquakes, we review some aspects of the regional plate tectonics.

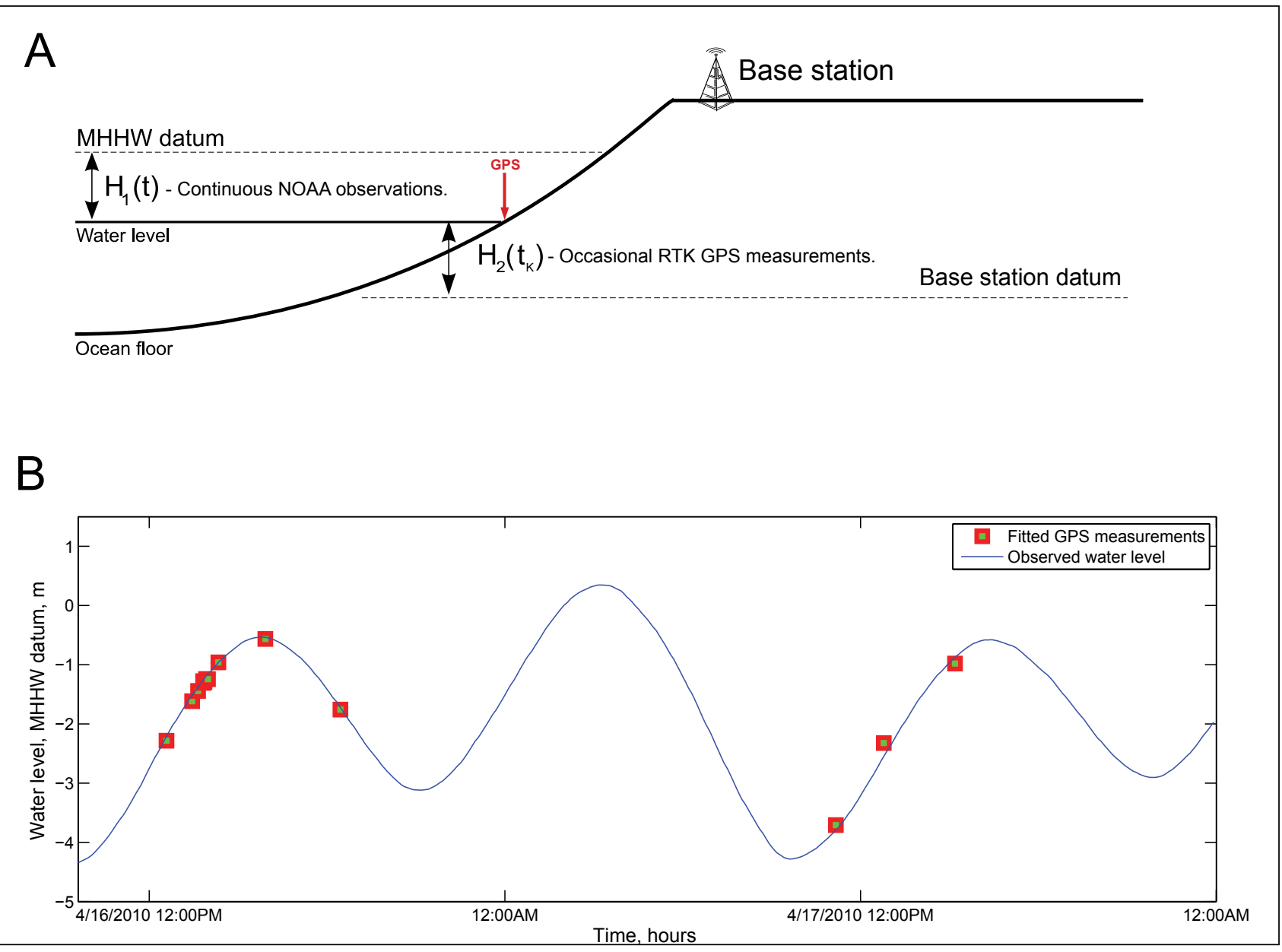

Figure 7. (A) Measurement of sea level in the MHHW datum and the relation of the base station datum to the MHHW datum. (B) Predicted water-level dynamics in Cordova and the fitted GPS measurements of the water level in the MHHW datum. 


\section{Regional Seismotectonics}

According to the segmentation model of Nishenko and Jacob (1990), south-central Alaska includes three segments of the megathrust: the Yakataga-Yakutat (YY), Prince William Sound (PWS), and Kodiak Island (KI) segments (fig. 8). Using seismic waveform data Christensen and Beck (1994) show that there were two areas of high moment release representing the two major asperities of the 1964 rupture zone: the Prince William Sound asperity with an average slip of $18 \mathrm{~m} \mathrm{(59} \mathrm{ft})$ and the Kodiak asperity with an average slip of $10 \mathrm{~m}$ (33 ft). Analysis of historical earthquake data in the PWS and KI segments (Nishenko and Jacob, 1990) showed that the KI segment produced significant megathrust earthquakes more frequently and also independently of the PWS segment. Paleoseismic data also show that the KI segment ruptured independently in a large earthquake about 500 years ago, about 360 years more recently than the penultimate great earthquake that ruptured both the KI and PWS segments (Carver and Plafker, 2008).

The results of joint inversion of tsunami and geodetic data from the 1964 earthquake (Johnson and others, 1996) also suggest the division of the rupture zone into two different segments. These segments have different recurrence intervals, with estimates of the recurrence interval for $\mathrm{M}_{\mathrm{S}} 7.5-8$ earthquakes in the KI segment being as low as 60 years (Nishenko,
1991 [as cited in Johnson and others, 1996]). On the basis of all published paleoseismic data for the region, Carver and Plafker (2008) calculated that the median intervals between the past eight great earthquakes $\mathrm{M}_{\mathrm{W}}>8$ in the PWS segment of the Aleutian megathrust range from 333 to 875 years, with an average 589 years.

The Yakataga-Yakutat area at the eastern end of the megathrust is a complex collision zone where the Yakutat microplate moves northwest toward central Alaska (Carver and Plafker, 2008; Freymueller and others, 2008). This segment translates predominantly strike-slip motion on its eastern side to shallow-dipping subduction on its west side (Nishenko and Jacob, 1990). The southern and eastern boundaries of the Yakutat block are well defined, but a collection of distributed fold and thrust zones, splay faults, and mountain-building regions complicates the northern and western edges of the block. We note that the interaction between the Yakutat block and the Pacific and North American plates is complex and poorly understood. Plafker and Thatcher (2008) re-evaluated the mechanisms of the two great Yakutat Bay earthquakes of September 1899 and showed that coseismic deformation was onshore uplift, explaining the absence of a tsunami in the Gulf of Alaska. Plafker and Thatcher (2008) concluded that the 1899 earthquake sequence most likely did not rupture through the offshore portion of the Yakataga seismic gap, a

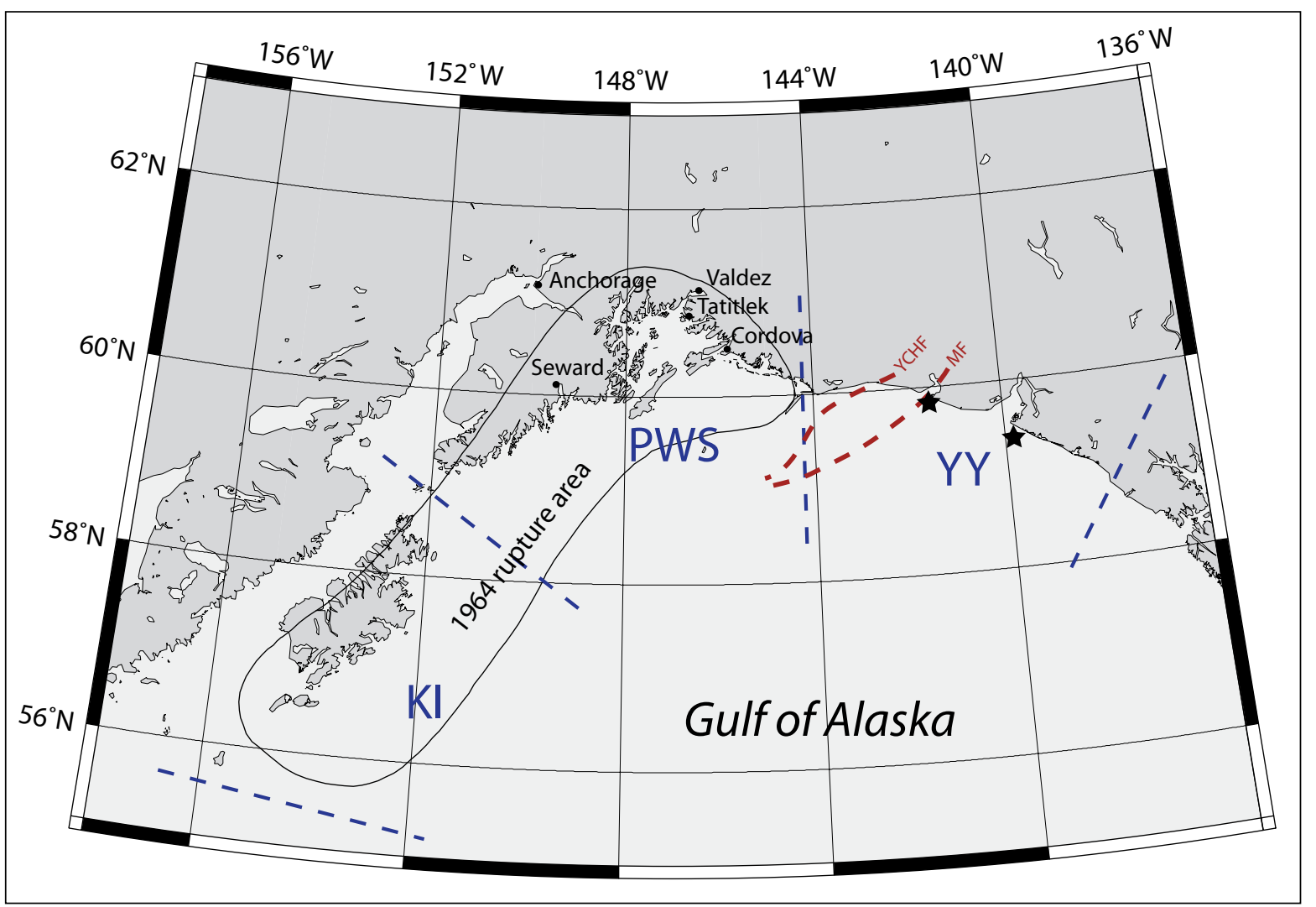

Figure 8. Map of south-central Alaska with rupture zone of the 1964 Great Alaska Earthquake and segments of the Alaska-Aleutian megathrust: the Prince William Sound (PWS), Kodiak Island (KI), and Yakataga-Yakutat (YY) segments. Stars indicate epicenters of two September 1899 earthquakes. The dashed red lines indicate a hypothetical offshore continuation of the Malaspina-Pamplona fault system (MF) and Yakataga-Chaix Hill fault (YCHF) system. 
region between the focal area of the 1899 earthquakes and the 1964 rupture area. This finding suggests that the YY segment has a high potential for a future tsunamigenic earthquake.

In a paleoseismic study of regional land subsidence at Kenai Peninsula sites, Hamilton and Shennan (2005) estimated coseismic subsidence during the 1964 earthquake and two earlier events. It was shown that an earthquake dated to 1,500-1,400 years B.P. produced more than twice the subsidence caused by the 1964 earthquake. By comparing the Kenai Peninsula sites with other sites around Cook Inlet, the authors found that each of the three great earthquakes in the study had a different pattern of coseismic subsidence. Shennan and others (2008) present geologic evidence of six prehistoric major tsunamigenic earthquakes in the Kenai Peninsula area of south-central Alaska in the past 4,000 years based on radiocarbon ages of tidal marsh deposits in Girdwood. The results of this study indicate variable recurrence intervals and both similarities and differences in temporal and spatial patterns over multiple earthquake cycles. Recent work by Shennan and others (2009) tests the hypothesis that in some seismic cycles, megathrust segments can, as proposed in the segmentation model by Nishenko and Jacob (1990), rupture simultaneously to produce earthquakes greater than historical events. Based on paleoseismic data, Shennan and others (2009) determined that earthquakes approximately 900 and 1,500 years B.P. simultaneously ruptured three adjacent segments of the Aleutian megathrust: the PWS and KI segments, and the Yakutat microplate (the YY segment). The rupture area of these earthquakes was estimated to be $23,000 \mathrm{~km}^{2}(9,000$ $\mathrm{mi}^{2}$ ) greater than that of the $\mathrm{M}_{\mathrm{W}} 9.2$ Great Alaska Earthquake of 1964 , and with a 15 percent larger seismic moment. These studies demonstrate that an understanding of the historical great earthquakes in the area is insufficient for comprehensive tsunami hazard assessment in south-central Alaska and that detailed studies of multiple great earthquakes are required.

\section{Tectonic Tsunami Sources}

We developed several hypothetical tsunamigenic earthquake models that are described in the rest of this section. For each model we performed a numerical modeling experiment to estimate the impact of potential tsunamis on Cordova and Tatitlek. The 1964 Great Alaska Earthquake ruptured the PWS and KI segments simultaneously (Christensen and Beck, 1994) and geologic evidence supports the possibility that the PWS and KI segments, as well as a portion of the Yakutat microplate, have ruptured simultaneously in the past (Shennan and others, 2009). Therefore, we consider hypothetical tsunamigenic earthquakes produced by combinations of the PWS, KI, and YY segment ruptures. In addition, we consider various crustal earthquake scenarios in the YY block, a hypothetical rupture of a normal fault in the eastern Prince William Sound region (Finn, 2012), as well as a rupture of the Cascadia subduction zone involving the Juan de Fuca Plate underlying the Pacific Ocean from mid-Vancouver Island in British Columbia. Finally, we consider Tohoku-type events in the Gulf of Alaska region and another hypothetical subduction-type tsunamigenic earthquake, which has different depth limits in the eastern and western parts of Prince William Sound.

\section{A. Models of the 1964 Great Alaska Earthquake}

The 1964 tectonic tsunami affected numerous communities along the Pacific Northwest coast, Hawaii, and Alaska. This tsunami was studied in depth by several investigators (Plafker and others, 1969; Wilson and Tørum, 1972). Plafker (1967) gives a detailed description of the motion observed on the Patton Bay fault during the Great Alaska Earthquake of 1964, and provides a full report of the surface rupture and fault motion as well as several pieces of evidence suggesting that the fault continues on the ocean floor well past the region where it is currently mapped. Holdahl and Sauber (1994) applied Plafker's description to construct their model of the Patton Bay fault, which was used in an inversion of geodetic data. Johnson and others (1996) used the results of Holdahl and Sauber (1994) to augment their joint inversion of geodetic and tsunami data and to further reconstruct coseismic deformation models of the 1964 earthquake.

In this study, we use two coseismic deformation models of the 1964 earthquake - the Johnson and others (1996) and the Suito and Freymueller (2009) models - to generate the vertical displacements of the sea floor during the earthquake. We hereafter reference Johnson and others (1996) as the Johnson deformation model (JDM) and Suito and Freymueller (2009) as the Suito deformation model (SDM).

Johnson and others (1996) derive a detailed slip distribution for the 1964 earthquake, with eight subfaults representing the KI asperity and nine subfaults representing the PWS asperity. One subfault was assigned to represent the Patton Bay fault. Johnson and others (1996) and Holdahl and Sauber (1994) used only the mapped extent of the fault, approximately $72 \mathrm{~km}$ (45 mi), despite evidence suggesting that the fault extends much farther to the southwest. For example, Suito and Freymueller (2009) found they could not fit all the GPS data accurately unless they extended the fault past the tip of the Kenai Peninsula. In the same report, Suito and Freymueller (2009) develop a coseismic deformation model of the 1964 earthquake based on a three-dimensional (3-D) viscoelastic model, which implements a realistic geometry with an elastic slab with a low dip angle. This coseismic model is not based on an inversion, but it resembles a recently published inversion model (Ichinose and others, 2007) as well as some previously proposed models (Holdahl and Sauber, 1994; Johnson and others, 1996; Santini and others, 2003).

The main difference between the JDM and the SDM is that the latter incorporates slightly higher slip near the downdip end of the rupture to explain the horizontal displacements. Additionally, the rupture in the SDM is assumed to occur deeper than in the JDM. Consequently, the deeper subfaults in the SDM produce smoother variation of the seafloor deformation than in the JDM. Both models introduce the Patton Bay splay fault to explain the excessive uplift at Montague Island. It is assumed in the JDM that the extent of this splay fault was not much larger than its subaerial outcrop on Montague Island. The SDM assumes that the same fault extends much 
farther to the west than was previous assumed by Holdahl and Sauber (1994) and Johnson and others (1996). We note that although the Patton Bay fault slipped approximately $10 \mathrm{~m}$ (33 ft) at the southwestern tip of Montague Island, there has yet to be a comprehensive submarine survey to document the extent of that splay fault.

Scenario 1. Repeat of the 1964 event: Source function based on coseismic deformation model by Johnson and others (1996) (JDM)

The 1964 earthquake vertical coseismic displacement is modeled as rupture by eight subfaults representing the Kodiak asperity and nine subfaults representing the Prince William Sound asperity. One subfault was assigned to represent the Patton Bay fault, although the contribution of this fault to the far-field tsunami waveform was negligible. The fault parameters required to compute seafloor deformation are the epicenter location, area, dip, rake, strike, and amount of slip on the fault. We use the equations of Okada (1985) to calculate distribution of coseismic uplift and subsidence resulting from this slip distribution. This source function was previously applied to calculation of the1964 tsunami inundation in the Kodiak and Kachemak Bay communities (Suleimani and others, 2002; 2005; Nicolsky and others, 2011b; 2013 [in press]). The vertical ground/ocean floor displacement according to the JDM is shown in figure 9a. The developed scenarios are summarized in table 2 .
Scenario 2. Repeat of the 1964 event: Source function based on coseismic deformation model by Suito and Freymueller (2009) (SDM)

This coseismic deformation model of the 1964 earthquake is based on a 3-D viscoelastic model, incorporating a realistic geometry with an elastic slab having a low dip angle. Suito and Freymueller (2009) employed a 3-D finite element method, GeoFEM, by Okuda and others (2003) to compute the coseismic displacements and used previous inversion models along with the critical features of the observations. See Suito and Freymueller (2009) for further details regarding the computations of the coseismic displacements. The vertical ground/ocean floor displacement according to the $\mathrm{SDM}$ is shown in figure $9 \mathrm{~b}$.

\section{B. Models of a Multi-Segment Earthquake: Kodiak Island, Prince William Sound, and YY Asperities}

As proposed by Shennan and others (2009) the Prince William Sound and Kodiak Island segments of the 1964 rupture area and a portion of the Yakutat microplate may rupture simultaneously. To evaluate whether this event would cause a damaging tsunami scenario for Cordova and Tatitlek, we constructed a source function of this multisegment rupture.

Table 2. All hypothetical scenarios used to model tsunami runup in Cordova and Tatitlek.

\begin{tabular}{|l|l|}
\hline \multicolumn{2}{|l|}{ Tectonic Scenarios } \\
\hline Scenario 1 & $\mathrm{M}_{\mathrm{w}} 9.2$ earthquake in the Gulf of Alaska region, repeat of the 1964 event, JDM \\
\hline Scenario 2 & $\mathrm{M}_{\mathrm{w}} 9.2$ earthquake in the Gulf of Alaska region, repeat of the 1964 event, SDM \\
\hline Scenario 3 & $\mathrm{M}_{\mathrm{w}} 9.3$ multi-segment earthquake based on the JDM \\
\hline Scenario 4 & $\mathrm{M}_{\mathrm{w}} 9.3$ multi-segment earthquake based on the SDM \\
\hline Scenario 5 & $\mathrm{M}_{\mathrm{w}} 8.7$ earthquake of the Yakutat-Yakataga segment \\
\hline Scenario 6 & $\mathrm{M}_{\mathrm{w}} 9.0-9.1$ earthquake in the Cascadia subduction zone \\
\hline Scenario 7 & $\begin{array}{l}\mathrm{M}_{\mathrm{w}} 8.8 \text { earthquake in the Gulf of Alaska region, based on case A of the slip distribution: 4-18 } \mathrm{km} \\
(2.5-11.2 \text { mi) depth, uniform slip along strike }\end{array}$ \\
\hline Scenario 8 & $\begin{array}{l}\mathrm{M}_{\mathrm{w}} 8.8 \text { earthquake in the Gulf of Alaska region, based on case C of the slip distribution: 12-30 km } \\
(7.5-18.6 \text { mi) depth, uniform slip along strike }\end{array}$ \\
\hline Scenario 9 & $\begin{array}{l}\mathrm{M}_{\mathrm{w}} 8.8 \text { earthquake in the Gulf of Alaska region, based on case D of the slip distribution: 4-18 km } \\
(2.5-11.2 \text { mi) depth, variable slip along strike }\end{array}$ \\
\hline Scenario 10 & $\begin{array}{l}\mathrm{M}_{\mathrm{w}} 8.8 \text { earthquake in the Gulf of Alaska region, based on case F of the slip distribution: 12-30 km } \\
(7.5-18.6 \text { mi) depth, variable slip along strike }\end{array}$ \\
\hline Scenario 11 & $\begin{array}{l}\mathrm{M}_{\mathrm{w}} 9.0 \text { earthquake in the Gulf of Alaska region: 4-18 km (2.5-11.2 mi) depth, uniform slip along } \\
\text { strike }\end{array}$ \\
\hline Scenario 12 & $\begin{array}{l}\mathrm{M}_{\mathrm{w}} 9.0 \text { earthquake in the Gulf of Alaska region: 4-18 km (2.5-11.2 mi) depth, variable slip along } \\
\text { strike }\end{array}$ \\
\hline Scenario 13 & $\begin{array}{l}\mathrm{M}_{\mathrm{w}} 8.8 \text { earthquake in the Gulf of Alaska region: 12-28 km (7.5-17.4 mi) to 17-30 km (10.6-18.6 mi) } \\
\text { depth, uniform slip along strike }\end{array}$ \\
\hline
\end{tabular}


A

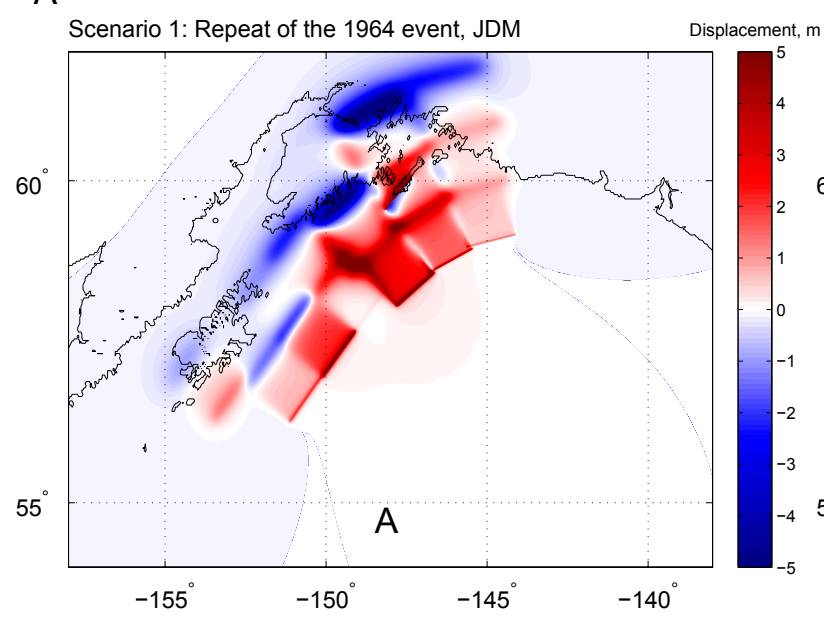

C

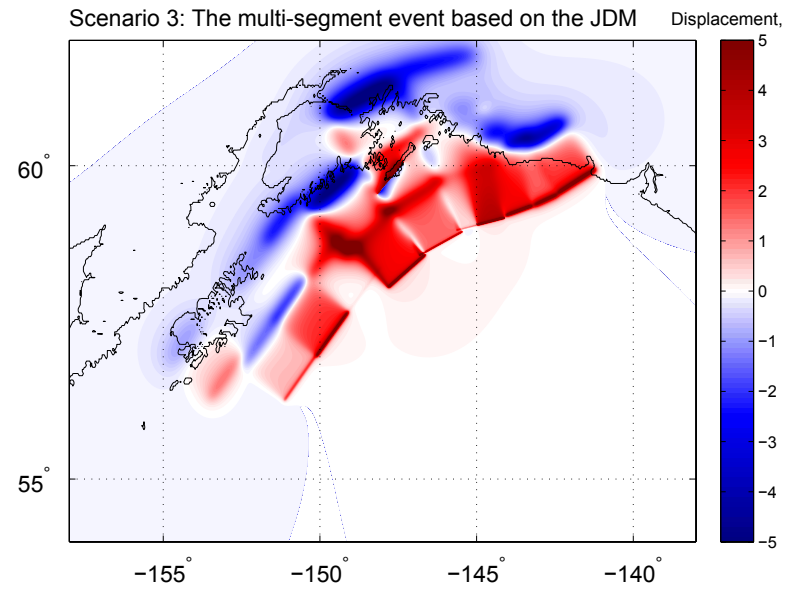

E

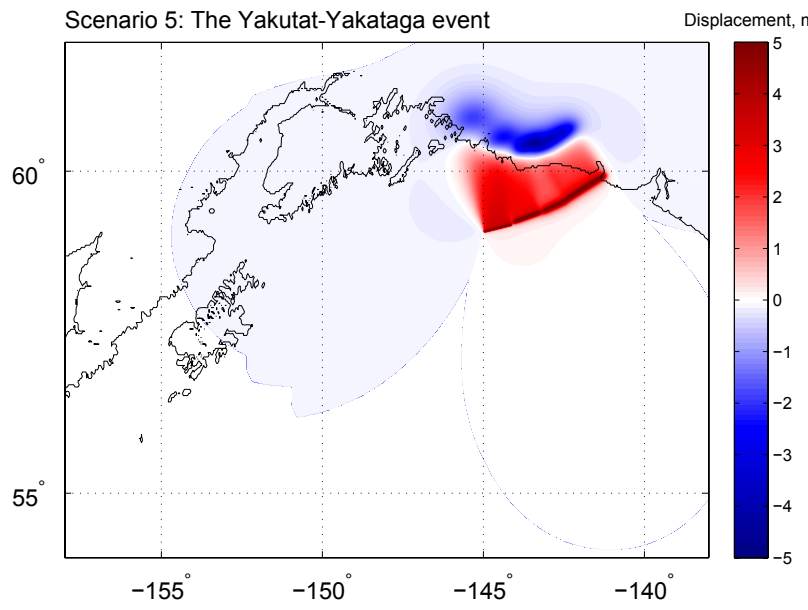

B

Scenario 2: Repeat of the 1964 event, SDM Displacement, $m$

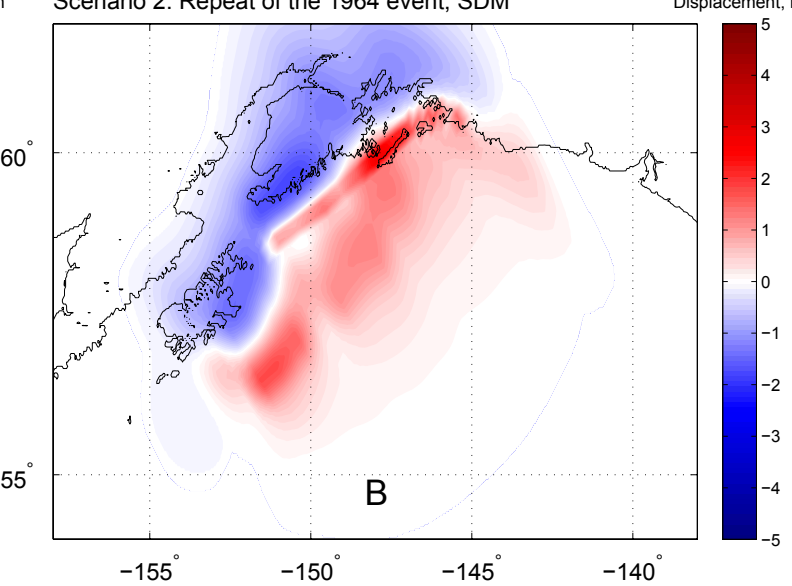

D

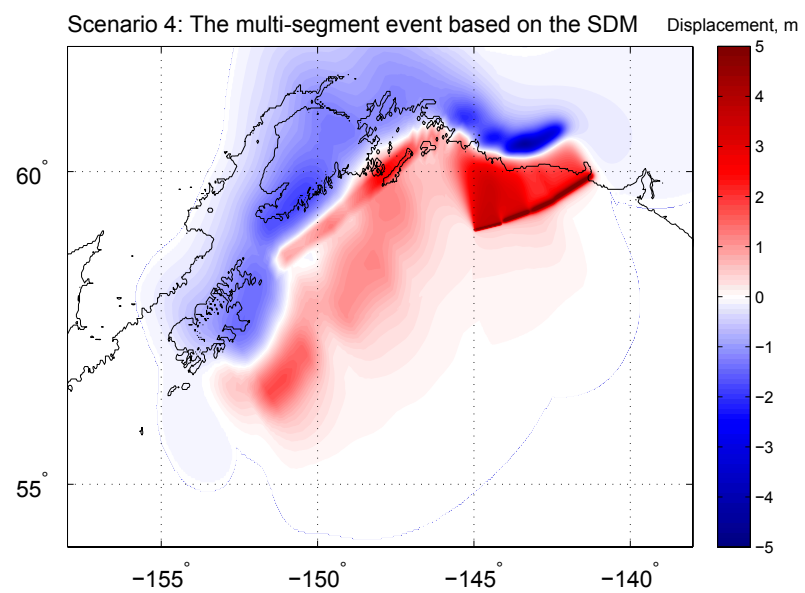

$\mathrm{F}$

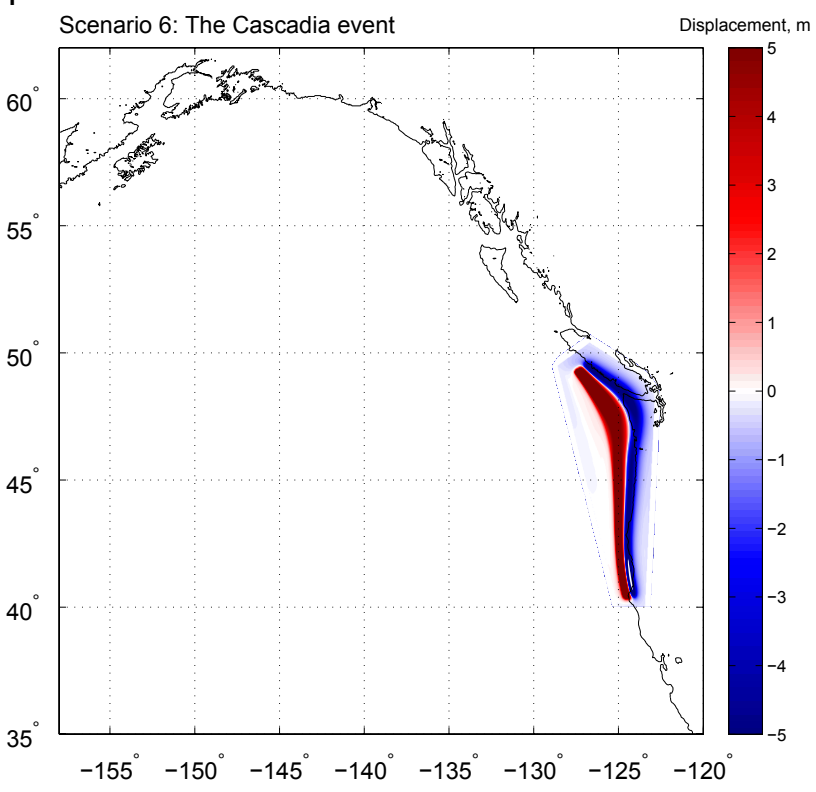

Figure 9. Vertical deformations of the ocean floor and adjacent coastal region, in meters, corresponding to scenarios 1-6. Red indicates uplift; blue indicates subsidence. 
We applied the following three constraints based on the hypothetical earthquake model of Shennan and others (2009). (1) The extended source function includes three segments of the Aleutian megathrust: the Prince William Sound (PWS), Kodiak Island (KI), and Yakataga-Yakutat (YY) segments. (2) The total seismic moment is about 15 percent greater than that of the 1964 earthquake. (3) The new source function produces coseismic vertical uplifts along the Gulf of Alaska coastline segment between the Copper River basin and Yakataga area in order to match the coseismic deformation pattern to paleoseismic data (Shennan and others, 2009).

To construct a rupture model for the YY segment, we assumed four subfaults whose parameters are listed in table 3 . We calculated coseismic deformations produced by this segment using Okada's algorithm (Okada, 1985), and then combined them with the 1964 coseismic deformations produced by the JDM and SDM.

Scenario 3. Multi-Segment JDM event: Source function based on extension of the JDM

The model in scenario 1 is extended by including a rupture model for the YY segment. The vertical coseismic deformation pattern for the extended 1964 rupture is shown in figure $9 \mathrm{c}$.

Scenario 4. Multi-Segment SDM event: Source function based on extension of the SDM

The model in scenario 2 is extended by including a rupture model for the YY segment. The vertical coseismic deformation pattern for the extended 1964 rupture is shown in figure $9 \mathrm{~d}$.

\section{Scenario 5. Rupture of the Yakutat-Yakataga segment}

The event is a hypothetical $\mathrm{M}_{\mathrm{w}} 8.7$ earthquake that ruptures only the YY segment, which we parameterize by four subfaults listed in table 3 . The vertical coseismic deformations for this scenario are shown in figure $9 \mathrm{e}$.

\section{Model of the Cascadia Subduction Zone Earthquake}

Paleoseismic records reveal that great tsunamigenic earthquakes occur in the Cascadia subduction zone repeatedly, with irregular intervals averaging about 500 years (Atwater, 1987), and are often accompanied by a tsunami. The latest trans-Pacific tsunami generated by an earthquake at Cascadia occurred in January 1700 (Satake and others, 1996; Atwater and others, 2005). No impact from the tsunami was noted by local communities, probably because of the low population density along the Alaska coast. Multiple models of the Cascadia zone rupture are suggested by Satake and others (2003) and Priest and others (2009) and in previous works they cite. These models describe hypothetical coseismic displacement fields of the Cascadia rupture, with various levels of detail. Because a Cascadia subduction zone earthquake is considered to be a medium-distance tsunami source to the south-central Alaska coast, a relatively simple "worst case, but credible" rupture of the Cascadia subduction zone is used in our modeling.

Scenario 6. Rupture of the Cascadia subduction zone, including portions of the margin along the British Columbia and northern California shores

Tsunami heights in Japanese historical records can constrain the slip distance of the 1700 Cascadia earthquake (Satake and others, 1996) but do not provide reliable constraints on the downdip limit of the rupture (Wang and others, 2003). A conservative approach for Cascadia is to assume that full coseismic rupture takes place over the entire locked zone and the slip decreases linearly downdip halfway into the present effective transition zone. The most recently updated and probably more reasonable model assumes that the slip distribution in the downdip direction is bell shaped on a plot of slip versus distance from the trench (Geological Survey of Canada, K. Wang, written commun., 2010), which is different from what was used to model the coseismic deformation shown in figure 14 of Wang and others (2003). In this report, the assumed rupture recovers 1,200 years of equivalent plate convergence (Witter and others, 2011), or about $36 \mathrm{~m} \mathrm{(120} \mathrm{ft)}$ of slip with magnitude $\mathrm{M}_{\mathrm{w}} \approx 9$. The vertical coseismic deformation for this scenario is shown in figure $9 \mathrm{f}$.

\section{Tectonic Source Models of Hypothetical Tsunamigenic Earthquakes in the Yakutat Block}

Elliott (2011) proposed a regional tectonic model for the St. Elias orogen based on GPS measurements of the surface deformation. This model is based on data collected from 65 GPS sites in southeastern and south-central Alaska from 2005 through 2009. The majority of these measurements were from newly established sites as part of the St. Elias Erosion/Tectonics Project (STEEP). Based on data analyses from this dataset, the region was subdivided into three blocks (Elias, Icy Bay, and Yakutat) separated by four fault systems (or fault zones): the Malaspina-Pamplona system,

Table 3. Fault parameters for the Yakataga-Yakutat (YY) segment

\begin{tabular}{|c|c|c|c|c|c|c|c|c|}
\hline $\begin{array}{c}\text { Latitude } \\
\text { (deg. } \mathbf{~})\end{array}$ & $\begin{array}{c}\text { Longitude } \\
(\mathbf{d e g} . \mathbf{W})\end{array}$ & $\begin{array}{c}\text { Depth } \\
(\mathbf{k m})\end{array}$ & $\begin{array}{c}\text { Length } \\
\mathbf{( k m )}\end{array}$ & $\begin{array}{c}\text { Width } \\
\mathbf{( k m )}\end{array}$ & $\begin{array}{c}\text { Strike } \\
(\mathbf{d e g} .)\end{array}$ & $\begin{array}{c}\text { Dip } \\
(\mathbf{d e g} .)\end{array}$ & $\begin{array}{c}\text { Rake } \\
(\mathbf{d e g} .)\end{array}$ & $\begin{array}{c}\text { Slip } \\
(\mathbf{m})\end{array}$ \\
\hline 59.17 & 144.12 & 1 & 50.1 & 190 & 256 & 12 & 90 & 15 \\
\hline 59.36 & 143.23 & 3 & 51.1 & 141 & 250.4 & 10 & 90 & 15 \\
\hline 59.54 & 142.42 & 5 & 47.8 & 114.8 & 245.8 & 6 & 90 & 15 \\
\hline 59.94 & 141.21 & 5 & 79.7 & 99.6 & 237.8 & 8 & 90 & 15 \\
\hline
\end{tabular}


the Yakataga-Chaix Hills system, the Foreland fault zone, and the decollement between the Yakutat block and the upper plate. The on-land fault locations were constrained with additional information from geologic maps, seismicity trends, and topographic features. Offshore locations of these fault zones, however, are not well constrained. The offshore continuation of the Malaspina-Pamplona and Yakataga-Chaix Hill systems (Elliott, 2011) are shown by dashed red lines in figure 8 . While this tectonic model fits well-observed crustal motions and provides an integrated kinematic view of regional tectonics, many uncertainties as to the extent in depth and strike of identified fault features remain. Our preliminary modeling of hypothetical scenarios based on rupture of the offshore continuation of the Malaspina-Pamplona and Yakataga-Chaix Hills systems (with about 600 years of the slip accumulation) indicate only a minor tsunami reaching to both Cordova and Tatitlek. Therefore, there is no added value to this report from these scenarios. Moreover, more scientific research is needed to further constrain the offshore continuations of the onshore fault zones.

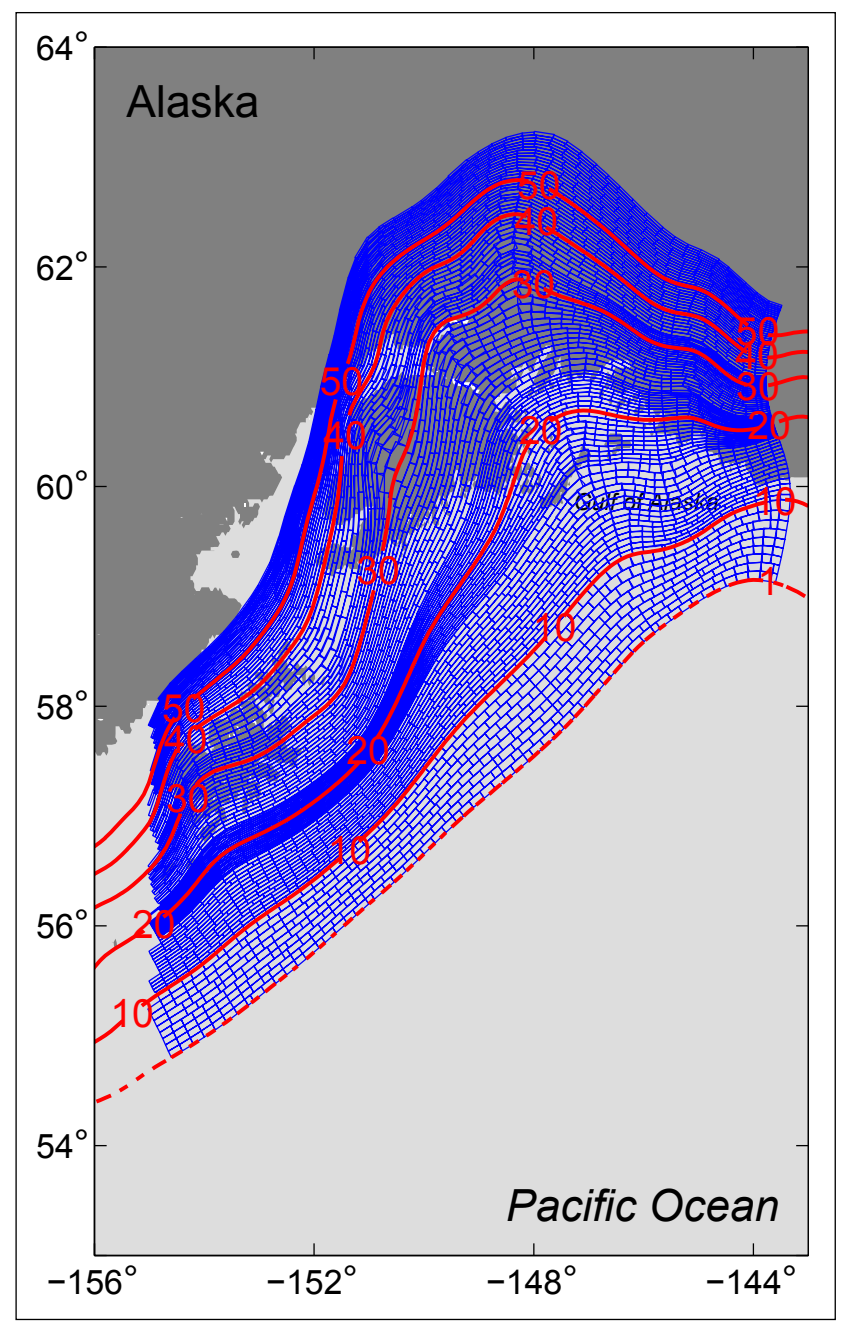

Figure 10. Discretization of the plate interface model into a set of rectangles used to compute the coseismic vertical displacement by formulas developed by Okada (1985). The red lines mark depth contours (in $\mathrm{km}$ ) of the reconstructed plate interface.

\section{E. Tectonic Source Models of Hypothetical Tsunamigenic Earthquakes Associated with Subsidence in Cordova and Tatitlek}

In recent studies, Carver and Plafker (2008) and Shennan and others (2008) present evidence of multiple great earthquakes rupturing the Alaska megathrust, and significant ground surface displacement along the Gulf of Alaska shoreline. Although estimated values of the ground subsidence and uplift are available at a limited number of locations (Hamilton and Shennan, 2005; Shennan and others, 2008; Carver and Plafker, 2008, and previous works they cite), these studies indicate that tectonic plates could have slipped differently relative to each other during each earthquake. The available ground deformation data are scarce and do not allow constraints on the slip distribution in eastern Prince William Sound or estimates on the location of the zero isobase between coseismic uplift and subsidence displacements during pre-1964 great megathrust events. The zero isobase during the 1964 event (Plafker, 1969) is thought to have been just south of Port Valdez, but it could have been slightly farther south. Uplift near Tatitlek and Cordova may have been smaller during pre-1964 events. If this is the case, it is possible that Cordova and Tatitlek could experience more devastating tectonic tsunamis than occurred in 1964. Thus, in addition to assessing the 1964-type events, we consider several hypothetical scenarios in which earthquakes rupture the plate interface beneath Prince William Sound, causing various amounts of surface deformation. We hypothesize that during such events hypothetical tsunamis arrive at Tatitlek and Cordova, which are significantly uplifted by the coseismic deformation.

To allow simulation of various earthquakes on the northeastern part of the megathrust, we employ a model of the Alaska-Aleutian plate interface between the subducting and overriding plates. The details of the plate interface reconstruction can be found in Nicolsky and others (2013 [in press]). The plate interface model is discretized into a number of small rectangles. The upper and lower edges of each rectangle coincide with a depth contour of the reconstructed plate interface (fig. 10). The rectangles, called subfaults, are later used to compute coseismic ground deformation using formulas developed by Okada (1985). Once the model of the plate interface was developed, we modeled the hypothetical earthquakes by prescribing a slip distribution along the interface and computing the slip at the center of each subfault. Similar to Geist and Dmowska (1999) and Sobolev and others (2007), we used theoretical slip distribution formulas by Freund and Barnett (1976) to model coseismic vertical deformation. The most important parameters in the Freund and Barnett formulas are the upper and lower boundaries of the hypothetical rupture in the local downdip direction. These boundaries prescribe a range of depths at which the hypothetical earthquake occurs.

In figure 11, we show six theoretical scenarios (based on cases A-F) of the slip distribution for $\mathrm{M}_{\mathrm{w}} 8.8$ earthquakes in the Prince William Sound region. Slip at the center of each subfault is in meters and is color coded. Depth contours of 


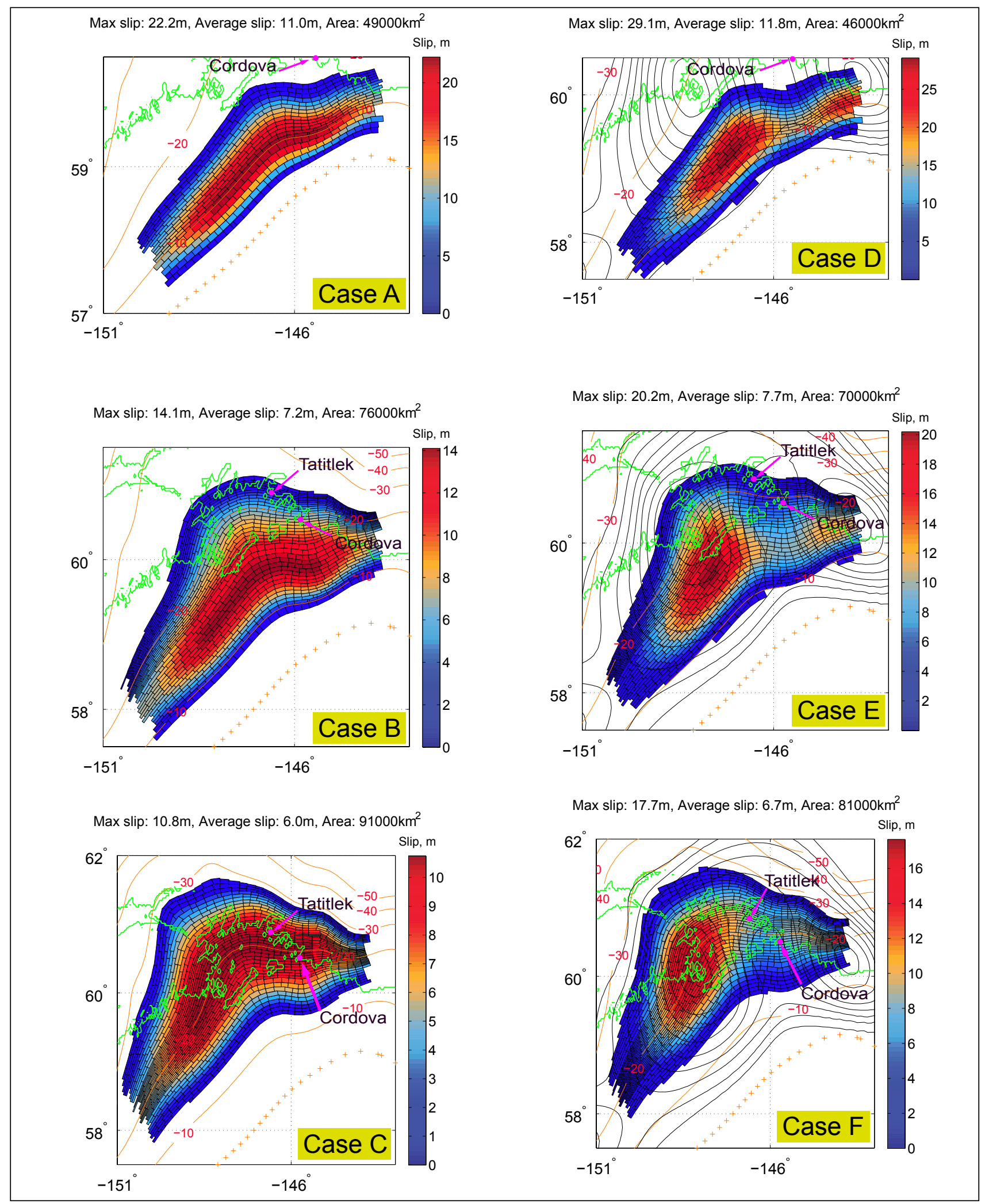

Figure 11. Proposed slip distribution along the plate interface for hypothetical cases $A$ through $F$ modeling a $M_{W} 8.8$ rupture in the Prince William Sound region. In cases A, B, and C the proposed slip distribution along the plate interface is uniform in the along-strike direction and is slightly tapered at both ends of the potential rupture. In cases $\mathbf{D}$, E, and $\mathbf{F}$ the proposed slip distribution along the plate interface in the along-strike direction is taken into account according to the slip deficit model by Suito and Freymueller (2009). The orange lines are associated with the depth contours of the megathrust in kilometers. The Alaska-Aleutian trench is marked with orange crosses. The slip deficit contours (from Suito and Freymueller, 2009) are shown by black lines. Locations of Cordova and Tatitlek are marked with magenta points. 

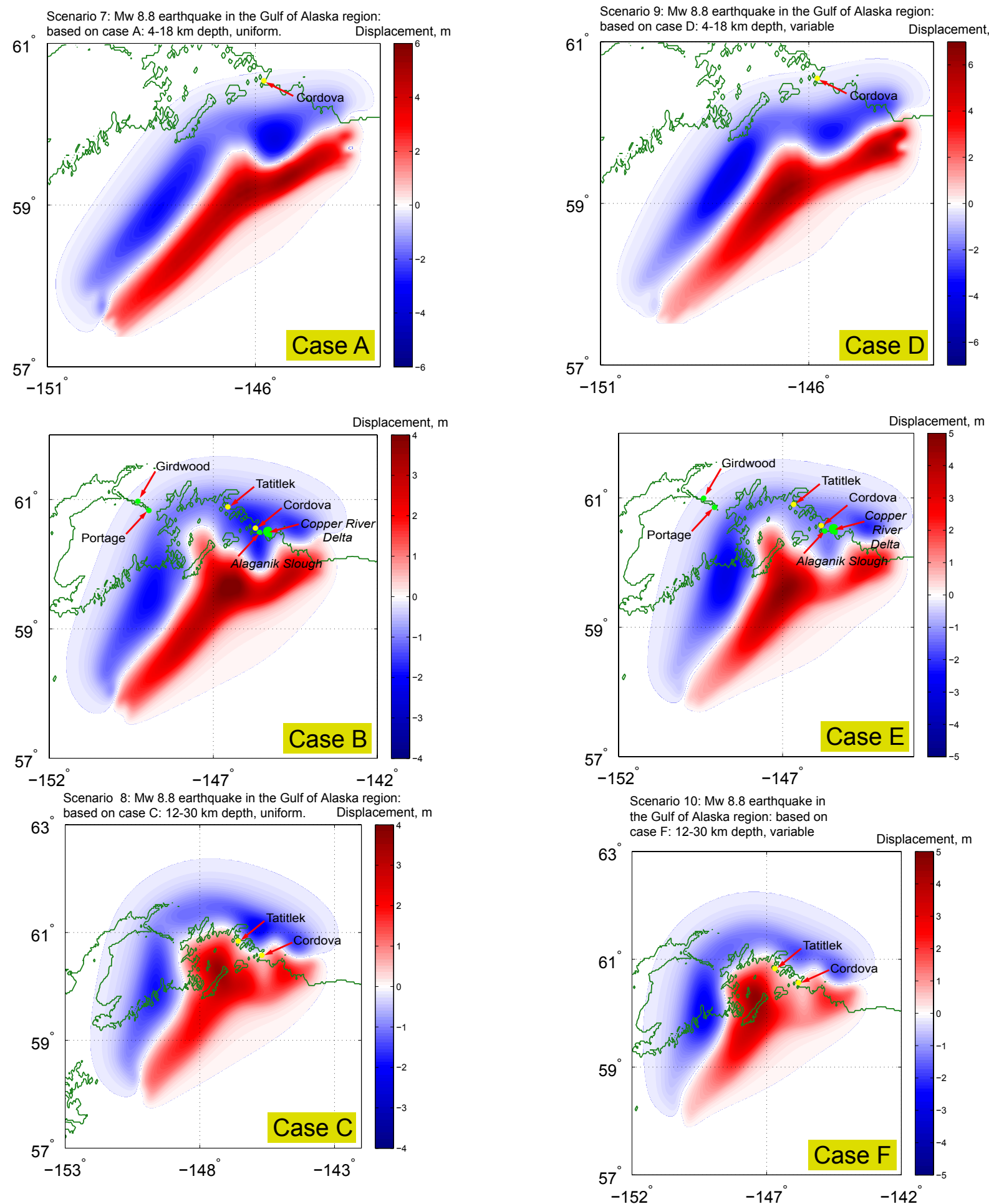

Figure 12. Computed vertical ground surface deformation related to cases $\mathbf{A}$ through $\mathbf{F}$ shown in figure 11 . Blue areas are associated with the coseismic ground subsidence, while the areas of uplift are shown in red. Note the location of the zero deformation line with respect to the location of the Copper River Delta. The deformation for cases $\mathbf{A}$ and $\mathbf{C}$ are included for scenarios 7 and 8, respectively. The deformation for cases $\mathbf{D}$ and $\mathbf{F}$ are included for scenarios 9 and 10 , respectively. Scenarios based on cases $B$ and $E$ are omitted because of geological constraints. Location of Cordova and Tatitlek are marked with yellow points. The locations with recorded data about previous patterns of coseismic uplift and subsidence are marked with bright green dots 


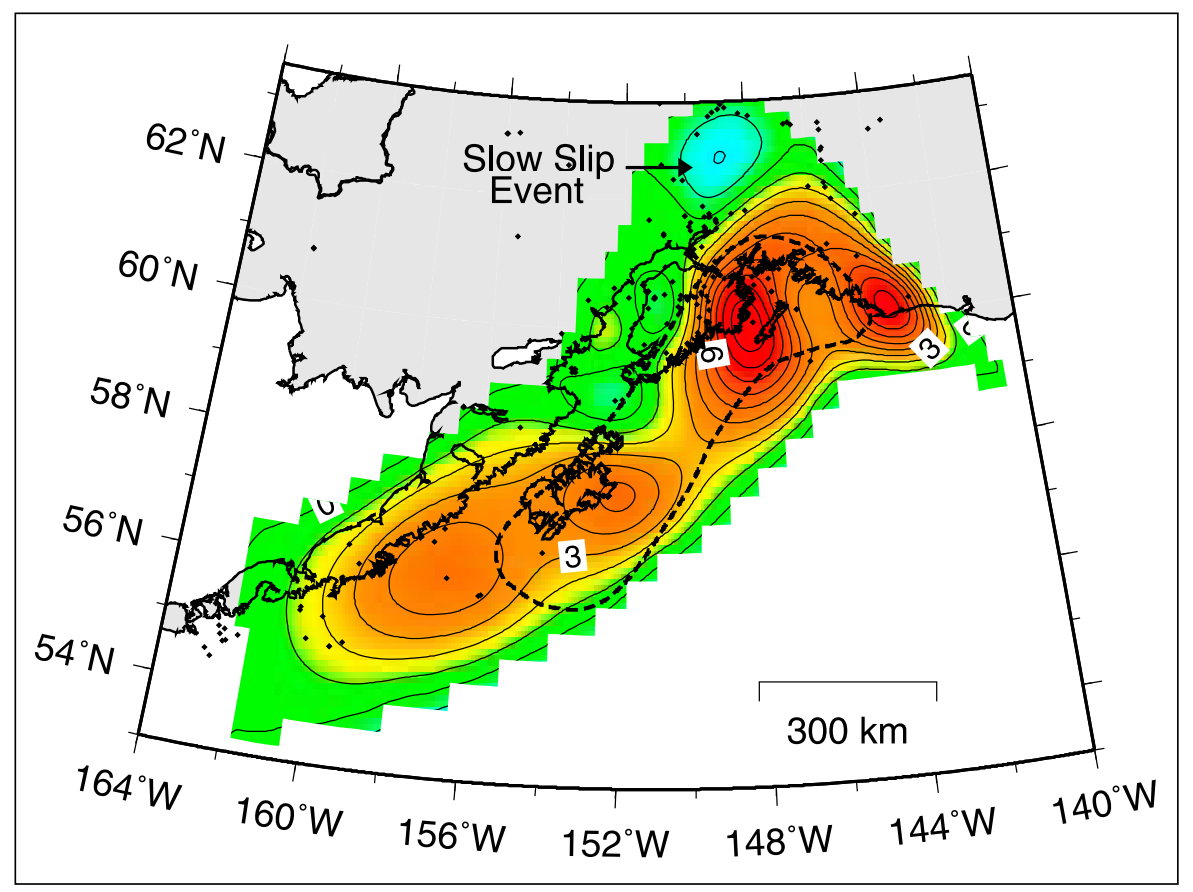

Figure 13. Contour plot (from Suito and Freymueller, 2009) of the interseismic slip deficit reconstruction with contour interval of $1 \mathrm{~cm} / \mathrm{yr}(0.39 \mathrm{in} / \mathrm{yr})$. Red colors are positive slip deficits, while blue colors are negative slip deficits (mainly the effect of the 1998-2001 slow slip event [Ohta and others, 2006]).

the plate interface model are in kilometers and shown by red lines. The locations of Cordova and Tatitlek are marked by magenta dots. In case A, the rupture occurs between depths of 4 and $18 \mathrm{~km}(2.5-11.2 \mathrm{mi})$; in case $\mathrm{B}$, the rupture is limited between depths of 8 and $24 \mathrm{~km}(5-15 \mathrm{mi})$; and in case $C$ the slip is distributed between depths of 12 and $30 \mathrm{~km}(7.5-18.6$ mi). The slip in the along-strike direction is thought to be distributed uniformly and is tapered at each end of the rupture zone. The vertical deformations for each case are displayed in figure 12. Blue shading indicates ground subsidence, while red marks areas of uplift.

A geodetic study by Zweck and others (2002) in south-central Alaska revealed the so-called locked regionssegments of the plate interface where the tectonic plates do not move relative to each other due to intense friction. Zweck and others (2002) showed that the locked regions are beneath the eastern Kenai Peninsula and western Prince William Sound at depths from 10 to $30 \mathrm{~km}(6.2-18.6 \mathrm{mi})$ and correlated this locked zone to the region of high slip during the 1964 earthquake. They concluded that the locked zone is associated with a persistent asperity. Suito and Freymueller (2009) estimated the slip deficit accumulating on the locked plate interface and found that most of the slip deficit (locking) occurs near Bainbridge and Evans islands in the southeastern Kenai Peninsula region. The estimated slip deficit contours from Suito and Freymueller (2009) are shown in figure 13.

Based on the slip deficit model of Suito and Freymueller (2009), we constructed scenarios, based on cases D, E, and F for hypothetical tsunamigenic earthquakes. Instead of assuming a uniform slip distribution in the along-strike direction of the potential rupture, slip was adjusted according to the slip deficit model. We note that the downdip extents of the rupture area in cases $\mathrm{D}, \mathrm{E}$, and $\mathrm{F}$ are equal to the extents in cases $\mathrm{A}, \mathrm{B}$, and C. The proposed slip distribution and vertical seafloor deformations for cases $\mathrm{D}, \mathrm{E}$, and $\mathrm{F}$ are shown in figures 11 and 12 .
In cases B and E, Alaganik Slough, Puffy Slough, and the Copper River Delta are located in a zone of subsidence and if such an earthquake occurs, these areas subside by $1.2-1.8$ $\mathrm{m}$ (4-6 ft). The closest locations for which paleoseismic data are available to estimate submergence are the Copper River Delta, Girdwood, and Portage. In the overview of paleoseismicity and neotectonics of the Aleutian subduction zone, Carver and Plafker (2008) indicated they had seen traces of the nine past subduction earthquakes that left a record of coseismic uplift in the Copper River Delta. Additionally, Shennan and others (2009) estimated that some parts of the Yakataga coast near the delta were coseismically uplifted by $\approx 1.5-2.0 \pm 0.5 \mathrm{~m}(4.9-6.6 \pm 1.6 \mathrm{ft})$ during the pre- 1964 event about 900 years B.P. Thus, subsidence at the Copper River Delta is unlikely in future earthquakes. At Girdwood the estimated submergence ranged from 0.7 to $\approx 1.5 \mathrm{~m}(2.3-4.9$ $\mathrm{ft}$ ) in six pre-1964 events dating to $\approx 3.7 \mathrm{ka}$ (Shennan and others, 2008 , p. 194) but was typically $\approx 1.5 \mathrm{~m}(4.9 \mathrm{ft})$ as in 1964. Shennan and others (2012) estimated subsidence at Portage for seven paleoseismic events recorded in a borehole. The four most recent and better constrained events, dating to $2.5 \mathrm{ka}$, yielded estimated submergence of $1.2-1.6 \pm 0.5$ $\mathrm{m}(3.9-5.2 \pm 1.6 \mathrm{ft})$. Note that in 1964 subsidence at Portage was $\approx 1.8 \mathrm{~m}(5.9 \mathrm{ft})$. Three older, less-well-constrained events had estimated submergence of $0.3-0.6 \pm 0.6 \mathrm{~m}(1-2 \pm 2 \mathrm{ft})$ (Shennan and others, 2012). The submergence can exceed tectonic subsidence in the Portage and Girdwood flats due to sediment compaction. The data at Girdwood, Portage, and the Copper River Delta seem to suggest that subsidence can vary by up to $\approx 1 \pm 0.5 \mathrm{~m}(3.3 \pm 1.6 \mathrm{ft})$. Considering that the uplift/subsidence variation could be larger or smaller at other locations across the deformation field, this range is the only geologic constraint to the potential coseismic deformation in Cordova and Tatitlek. 
We hypothesize that the uplift in Cordova and Tatitlek may vary within the same range as the subsidence/uplift in Girdwood, Portage, and the Copper River Delta. Recall that the scenario based on cases B and E results in $1.2-1.8 \mathrm{~m}$ (3.9-5.9 ft ) of subsidence near the Copper River Delta and eastern Prince William Sound. The latter value is likely to be outside of plausible limits from a geological perspective, given that the Copper River Delta tectonically uplifted by 1.8-2.4 $\mathrm{m}(5.9-7.9 \mathrm{ft})$ during the 1964 event. Therefore, although all above-considered scenarios of the $\mathrm{M}_{\mathrm{w}} 8.8$ earthquake are theoretically plausible from a seismological point of view, the scenarios based on cases B and E are omitted because of the geological constrains. Note that the potential earthquakes based on cases A and D do not result in subsidence in eastern Prince William Sound and can be considered low-probability events resulting in some subsidence along the Copper River Delta.

Scenario 7. $M_{w} 8.8$ earthquake in the Gulf of Alaska region, based on hypothetical Case A: 4-18 km (2.5-11.2 mi) depth, uniform slip along strike

This event is a hypothetical $\mathrm{M}_{\mathrm{W}} 8.8$ earthquake rupturing the Prince William Sound asperity of the 1964 earthquake. The slip is uniformly distributed in the along-strike direction of the plate interface and is localized between 4 and $18 \mathrm{~km}$ (2.5-11.2 mi) depth according to the parameterization by Freund and Barnett (1976). The proposed slip distribution is shown in figure 11a; vertical coseismic deformation for this scenario is shown in figure 12a.

Scenario 8. $\mathrm{M}_{\mathrm{w}} 8.8$ earthquake in the Gulf of Alaska region, based on hypothetical Case C: 12-30 km (7.5-18.6 mi) depth, uniform slip along strike

This event is a hypothetical $\mathrm{M}_{\mathrm{w}} 8.8$ earthquake rupturing the Prince William Sound asperity of the 1964 earthquake. The slip is uniformly distributed in the along-strike direction of the plate interface and is localized between 12 and $30 \mathrm{~km}$ (7.5-18.6 $\mathrm{mi}$ ) depth according to the parameterization by Freund and Barnett (1976). The proposed slip distribution is shown in figure 11c; vertical coseismic deformation for this scenario is shown in figure $12 \mathrm{c}$.

Scenario 9. $M_{w} 8.8$ earthquake in the Gulf of Alaska region, based on hypothetical Case D: 4-18 km (2.5-11.2 mi) depth, variable slip along strike

This event is a hypothetical $\mathrm{M}_{\mathrm{W}} 8.8$ earthquake rupturing the Prince William Sound asperity of the 1964 earthquake. The slip is distributed in the along-strike direction according to the slip deficit model (Suito and Freymueller, 2009) and is localized between 4 and $18 \mathrm{~km}(2.5-11.2 \mathrm{mi})$ depth according to the parameterization by Freund and Barnett (1976). The proposed slip distribution is shown in figure $11 \mathrm{~d}$; vertical coseismic deformation for this scenario is shown in figure $12 \mathrm{~d}$.

Scenario 10. $M_{w} 8.8$ earthquake in the Gulf of Alaska region, based on hypothetical Case F: $12-30 \mathrm{~km}$ (7.5-18.6 mi) depth, variable slip along strike

This event is a hypothetical $\mathrm{M}_{\mathrm{W}} 8.8$ earthquake rupturing the Prince William Sound asperity of the 1964 earthquake. The slip is distributed in the along-strike direction according to the slip deficit model (Suito and Freymueller, 2009) and is localized between 12 and $30 \mathrm{~km}(7.5-18.6 \mathrm{mi})$ depth according to the parameterization by Freund and Barnett (1976). The proposed slip distribution is shown in figure 11f; vertical coseismic deformation for this scenario is shown in figure $12 \mathrm{f}$.

\section{F. Tectonic Source Models of Normal Fault Earthquakes in Prince William Sound}

Finn (2012) interpreted bathymetric data and marine seismic reflection profiles in Orca Bay and identified several steep, basin-bounding normal faults on the seafloor. These faults are inferred to root into the hanging wall of thrust faults related to the megathrust subduction system. Based on increasing reflector offsets with depth and assuming constant Holocene sedimentation rates, Finn (2012) inferred that the faults are active with slip rates of between 0.6 and $1.4 \mathrm{~m}(2.0-4.6 \mathrm{ft})$ per thousand years. Assuming that these faults rupture in concert with subduction zone events, Finn (2012) used the average recurrence interval of megathrust earthquakes and the interpreted slip rates to estimate slip of about $1.5 \mathrm{~m}(\sim 5 \mathrm{ft})$ per event on the Orca Bay faults. Further, using the mapped length of the faults $(40 \mathrm{~km}[25 \mathrm{mi}])$ and empirical relations, Finn (2012) suggested that an independent $\mathrm{M}_{\mathrm{W}} 7.1$ earthquake is possible. We transferred the fault from Finn (2012; fig. 18) onto a new map to evaluate the merits of modeling potential tsunamis caused by earthquakes on this fault.

To construct a rupture model for the normal faults, we assumed four subfaults whose parameters are listed in table 4 . We calculated coseismic deformations produced by this segment using Okada's algorithm (Okada, 1985), and found that the modeled subsidence (Tatitlek) and uplift (Cordova) is less than $0.05 \mathrm{~m} \mathrm{(2} \mathrm{in).} \mathrm{Furthermore,} \mathrm{our} \mathrm{preliminary} \mathrm{modeling}$ for this rupture model indicates a wave of less than $0.2 \mathrm{~m}$

Table 4. Fault parameters for normal faults in the eastern Prince William Sound region.

\begin{tabular}{|c|c|c|c|c|c|c|c|c|}
\hline $\begin{array}{c}\text { Latitude } \\
\text { (deg. } \mathbf{N})\end{array}$ & $\begin{array}{c}\text { Longitude } \\
(\mathbf{d e g} . \mathbf{W})\end{array}$ & $\begin{array}{c}\text { Depth } \\
\mathbf{( k m )}\end{array}$ & $\begin{array}{c}\text { Length } \\
\mathbf{( k m )}\end{array}$ & $\begin{array}{c}\text { Width } \\
\mathbf{( k m )}\end{array}$ & $\begin{array}{c}\text { Strike } \\
(\mathbf{d e g} .)\end{array}$ & $\begin{array}{c}\text { Dip } \\
\mathbf{( d e g . )}\end{array}$ & $\begin{array}{c}\text { Rake } \\
(\mathbf{d e g} .)\end{array}$ & $\begin{array}{c}\text { Slip } \\
(\mathbf{m})\end{array}$ \\
\hline 60.66 & 145.99 & 0 & 10 & 15.5 & 236.46 & 75 & -90 & 1.5 \\
\hline 60.61 & 146.15 & 0 & 10 & 15.5 & 269.99 & 75 & -90 & 1.5 \\
\hline 60.64 & 146.35 & 0 & 10 & 15.5 & 262.42 & 75 & -90 & 1.5 \\
\hline 60.63 & 146.53 & 0 & 10 & 15.5 & 259.43 & 75 & -90 & 1.5 \\
\hline
\end{tabular}


( 8 in) in both communities. Therefore, it is possible that the normal faults might rupture in the Prince William Sound region in concert with the subduction scenarios, however their contribution to the tsunami is considered minor.

\section{G. Tectonic Source Models of Hypotheti- cal Tohoku-type Events in the Gulf of Alaska}

In view of the recent $\mathrm{M}_{\mathrm{W}} 9.0$ earthquake off the Pacific coast of Tohoku in 2011, we consider a similar-type event in the Gulf of Alaska region (David Scholl, USGS, oral commun., 2013; Jeffrey Freymueller, UAF, oral commun., 2013). During this event a large amount of slip between the subducting and overriding plates occurred near the Japan trench (Fujii and others, 2011; Shao and others, 2011).

In this report, we model hypothetical Tohokutype events in the Gulf of Alaska region by modifying cases A and D. Recall that the hypothetical rupture in these two cases is close to the trench and is between depths of 4 and $18 \mathrm{~km}(2.5-11.2 \mathrm{mi})$. However, instead of modeling a $\mathrm{M}_{\mathrm{W}} 8.8$ event as earlier, we now assume that the moment magnitude for this type of hypothetical event is 9.0 and scale the proposed slip distribution shown in figures 11a and $11 \mathrm{~d}$ accordingly.

Scenario 11. $M_{w} 9.0$ earthquake in the Gulf of Alaska region: 4-18 km (2.5-11.2 mi) depth, uniform slip along strike

This event is a hypothetical Tohoku-type event rupturing the Prince William Sound asperity of the 1964 earthquake. The slip is uniformly distributed

Figure 14. Proposed slip distribution along the plate interface for hypothetical Tohoku-type $M_{w} 9.0$ events in the Gulf of Alaska region. (A) Proposed slip distribution along the plate interface is uniform in the along-strike direction and is slightly tapered at both ends of the potential rupture. (B) Proposed slip distribution along the plate interface in the along-strike direction is taken into account according to the slip deficit model by Suito and Freymueller (2009). The slip deficit contours are shown by black lines. (C) $A M_{w} 8.8$ event rupturing the Prince William Sound region such that it maximizes the potential coseismic uplift inside the Sound but satisfies other geological constraints at all other locations. Orange lines are associated with depth contours in kilometers. The Alaska-Aleutian trench location is marked with orange crosses. Locations of Cordova and Tatitlek are marked with yellow-orange dots.

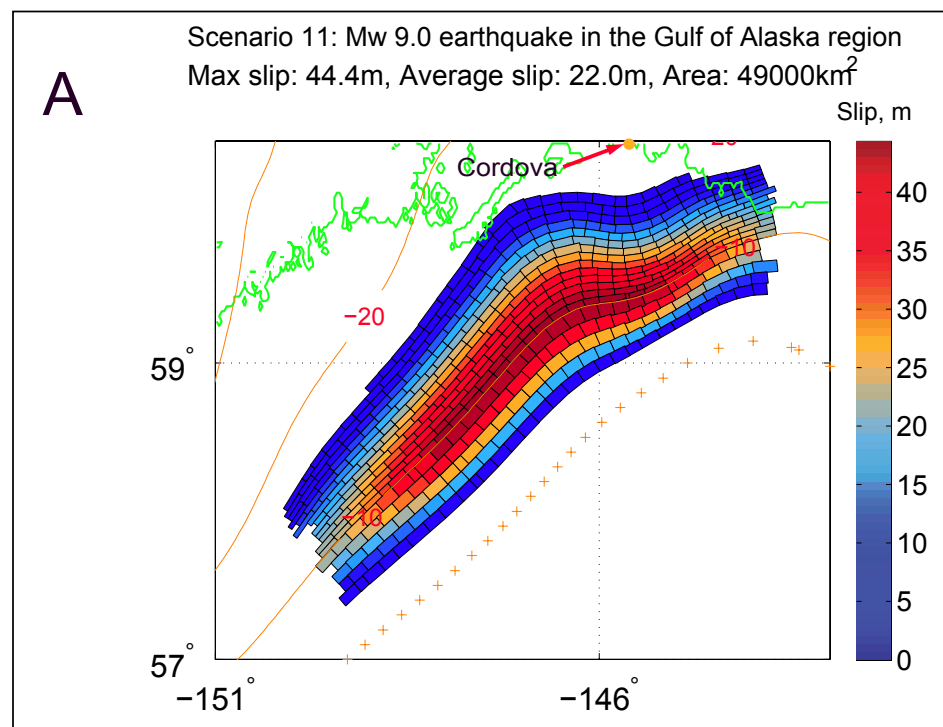

B Max slip: $58.1 \mathrm{~m}$, Average slip: $23.6 \mathrm{~m}$, Area: $46000 \mathrm{~km}^{2}$

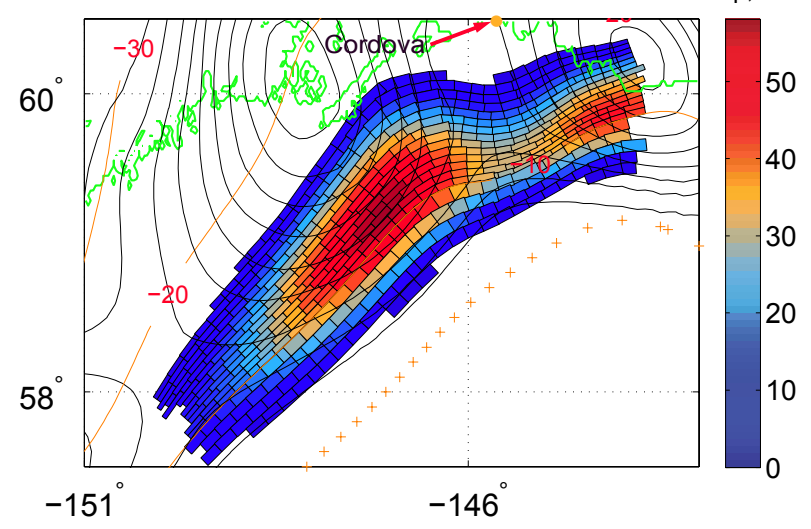

Scenario 13: Mw 8.8 earthquake in the Gulf of Alaska region Max slip: $19.5 \mathrm{~m}$, Average slip: $8.6 \mathrm{~m}$, Area: $63000 \mathrm{~km}^{2}$

Slip, $m$

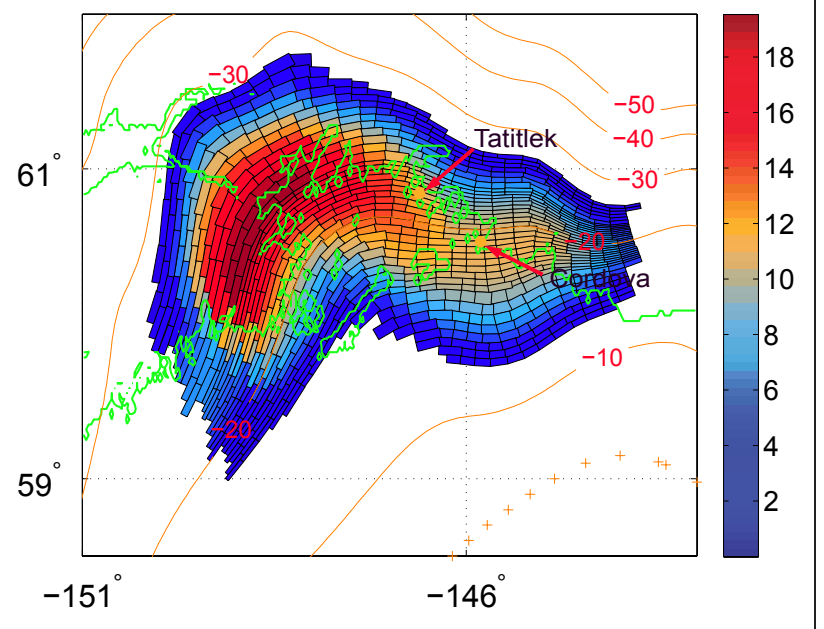




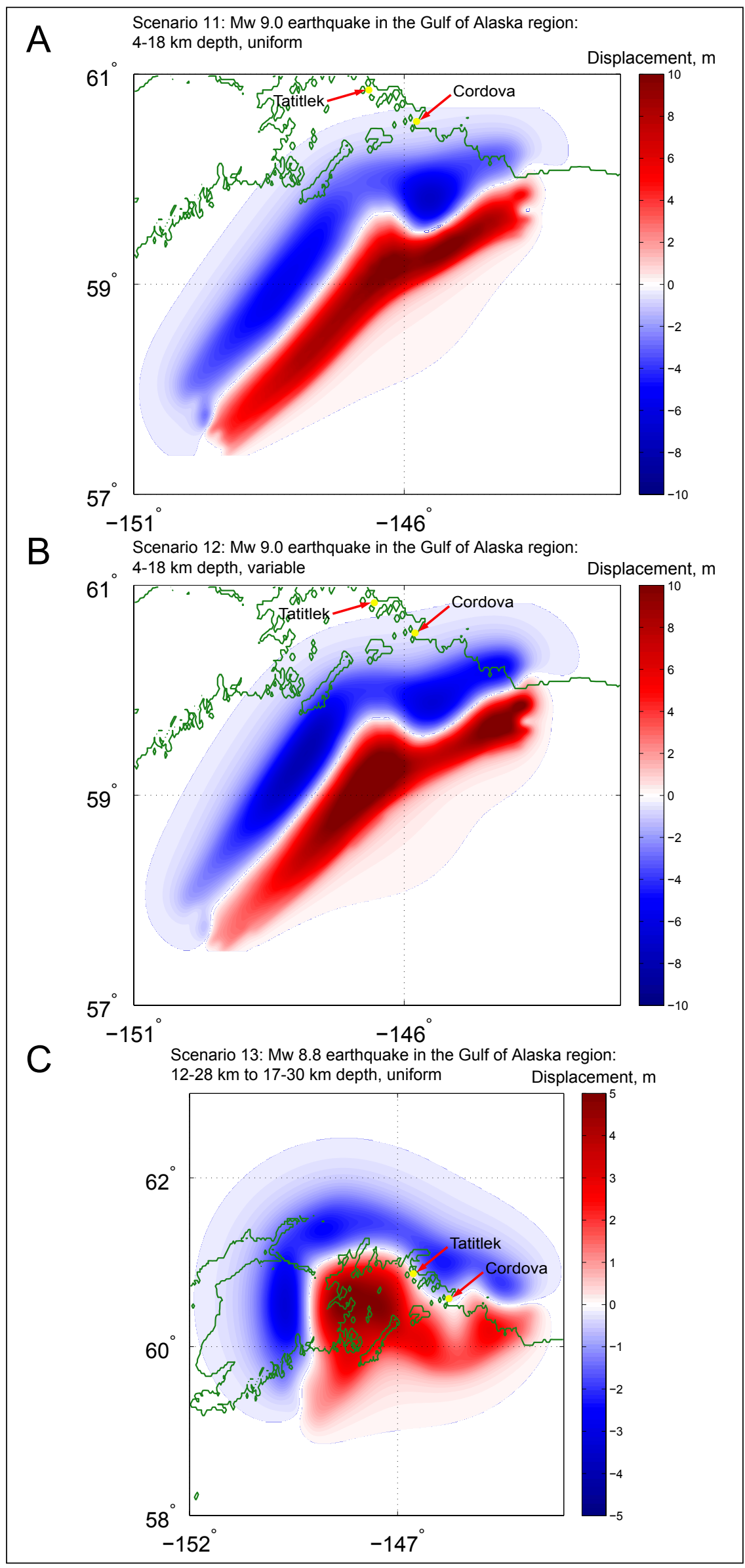

in the along-strike direction and is localized between 4 and $18 \mathrm{~km}$ (2.5-11.2 mi) depth according to the parameterization by Freund and Barnett (1976). The proposed slip distribution is shown in figure 14a; vertical coseismic deformation for this scenario is shown in figure 15a.

Scenario 12. $M_{w} 9.0$ earthquake in the Gulf of Alaska region: 4-18 $\mathrm{km}$ (2.5-11.2 mi) depth, variable slip along strike

This event is a hypothetical Tohokutype event rupturing the Prince William Sound asperity of the 1964 earthquake. The slip is distributed in the along-strike direction according to the slip deficit model (Suito and Freymueller, 2009) and is localized between 4 and $18 \mathrm{~km}(2.5-11.2 \mathrm{mi})$ depth according to the parameterization by Freund and Barnett (1976). The proposed slip distribution is shown in figure $14 \mathrm{~b}$; vertical coseismic deformation for this scenario is shown in figure $15 \mathrm{~b}$.

\section{H. Tectonic Source Models of the Earthquake With Spa- tially Varying Depth Limits}

Finally, we consider a hypothetical rupture for which the slip in the eastern part of the plate interface, near the Copper River Delta in the downdip direction, is localized between 15 and $23 \mathrm{~km}(9.3-14.3 \mathrm{mi})$ and is between 21 and $25 \mathrm{~km}(13.0$ $15.5 \mathrm{mi}$ ) depth in the rest of the Prince William Sound region. The proposed slip distribution is shown in figure $14 \mathrm{c}$. The proposed distribution of slip is to satisfy the geological

Figure 15. Computed vertical ground surface deformation related to the proposed slip distributions shown in figure 14. Blue areas are associated with coseismic ground subsidence, while areas of uplift are shown in red. Note location of zero deformation line with respect to the Copper River Delta. 
constraints (such as an uplift in the Copper River Delta region and some limited subsidence in Portage) and some tectonic considerations (a maximum of the proposed slip is close to a maximum of the slip deficit), and to maximize an uplift of water inside Prince William Sound. In addition to these requirements, the maximum and average slip on the plate interface as well as the rupture zone area have to match magnitude-slip displacement scaling relationships developed for subduction earthquakes (Papazachos and others, 2004; Moss and Travasarou, 2006). The vertical seafloor deformations are shown in figure $15 \mathrm{c}$.

Scenario 13. $M_{w} 8.8$ earthquake in the Gulf of Alaska region: $12-28 \mathrm{~km}$ (7.5-17.4 mi) to $17-30 \mathrm{~km}(10.6-18.6$ mi) depth, uniform slip along strike

This event is a hypothetical $\mathrm{M}_{\mathrm{W}} 8.8$ earthquake rupturing the Prince William Sound asperity of the 1964 earthquake. The slip in the along-strike direction mimics the slip deficit model (Suito and Freymueller, 2009) and is localized between 12 and $28 \mathrm{~km}(7.5-17.4 \mathrm{mi})$ depth in the Copper River Delta and between 17 and $30 \mathrm{~km}(10.6-18.6 \mathrm{mi})$ in the rest of the Prince William Sound region according to the parameterization by Freund and Barnett (1976). The vertical coseismic deformations for this scenario are shown in figure $15 \mathrm{c}$.

\section{Tectonic Source Models of Hypothetical Tsunamigenic Earthquakes in the Yakutat Block}

Outer-rise earthquakes are known to occur in the subducting plate in the vicinity of the oceanic trench and can be subdivided into two groups: tensional (normal) and compressional (thrust) events (Stauder, 1968; Byrne and others, 1988). Great tensional outer-rise events occurred near Japan on March 2, 1933 (the $\mathrm{M}_{\mathrm{w}} 8.4$ Sanriku-oki earthquake [Kanamori, 1971]) and near Indonesia on August 19, 1977 (the $\mathrm{M}_{\mathrm{w}} 8.3$ Sumba earthquake [Gusman and others, 2009]). At least 24 significant outer-rise events have occurred along the Aleutian-Alaska Arc (Christensen and Ruff, 1988).

Great outer-rise earthquakes are thought to be capable of rupturing through the entire oceanic lithosphere in response to the pull of the down-dipping slab. As a result, the Sanrikuoki and Sumba earthquakes generated a significant tsunami that resulted in at least 3,000 deaths in Japan and 189 deaths in Indonesia. The recent comparable $\mathrm{M}_{\mathrm{W}} 8.02009$ Samoa event also generated a significant tsunami that propagated throughout the Pacific Ocean.

In this report, we consider a hypothetical $\mathrm{M}_{\mathrm{w}} 8.3$ outerrise event in the Gulf of Alaska and parameterize it by five subfaults with the length of $50 \mathrm{~km}(31 \mathrm{mi})$ and width of 20 $\mathrm{km}(12 \mathrm{mi})$. It is assumed that the slip on each subfault is 20 $\mathrm{m}(66 \mathrm{ft})$ and it is the dip angle is $45^{\circ}$. After computing the sea floor deformation and tsunami dynamics, we find that a maximum wave height near Cordova according to this scenario is less than $0.3 \mathrm{~m}(1 \mathrm{ft})$ and in Tatitlek Narrows is less

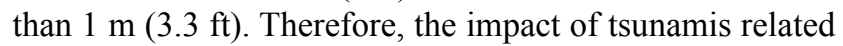
to outer rise events is less than our worst case scenarios and not considered further. Moreover, more scientific research is needed to further constrain the offshore location of potential outer-rise events before accurate modeling can be conducted.

A summary of each of the scenarios is provided in table 2.

\section{MODELING RESULTS}

\section{Numerical modeling of the 1964 tsunami in Cordova and Tatitlek}

In this section, we compare inundation modeling results of the 1964 tsunami in Cordova and Tatitlek with observations. The constructed DEMs are consistent with the present-day bathymetry/topography and were not edited to remove post1964 construction in the harbor area. We emphasize that following the 1964 earthquake, Orca Inlet was extensively dredged and some areas, such as around Hawkins Island, were the subject of significant tsunami-induced redistribution of the sediments (fig. 122 in Wilson and Tørum, 1972). For example, the consecutive post-earthquake soundings completed about two weeks apart show development of up to 3-4.6 m (10-15 ft) of erosion fill in a channel between Hawkins and Hinchinbrook islands. We thus note that the Orca Inlet bathymetry during the earthquake could have been significantly different from its present configuration.

We describe modeling of the 1964 tsunami in Cordova and Tatitlek by employing the JDM. Modeling results obtained with the SDM are similar and are omitted for the sake of brevity. Recall that Orca Inlet is rather shallow, and hence the modeled tsunami dynamics might differ depending on whether the tsunami is simulated on the low or on the high tide. We analyze sensitivity of the modeling results related to different tide levels by adjusting the DEM datum. For example, to model the tsunami at the low/high tide level, the DEM's vertical datum is set to the MLLW/MHHW level.

Our numerical experiments show that the tsunami arrives at Cordova from Orca Bay after propagating around the northern tip of Hawkins Island and then along Orca Inlet from the north to south. The southern part of Orca Inlet is shallow, and at low tide the mud flats are typically exposed in this region. From the modeling point of view, the shallow areas represent a constriction and the southward-propagating waves are partially reflected back to Orca Inlet instead of continuing toward the Gulf of Alaska. In figure 16a, we show the computed water level dynamics at the present location of the Cordova harbor while assuming that the tsunami occurs at the constant low or high tide level. The numerical experiment reveals that the modeled wave heights are larger if the 1964 tsunami is simulated on the low tide, when the mud flats are exposed. Nevertheless, both simulations show five distinct waves in the Cordova harbor. The amplitude of these waves increases, with the highest wave arriving shortly after midnight. Recall that according to the Harbormaster's report, there were six waves, with the last one coinciding with high tide. The difference in the modeled tsunami dynamics emphasizes that an interaction of the astronomic tide with the tectonic tsunami might be important near Cordova. Unfortunately, the current numerical model does not simulate a periodic change of sea level resulting from tides. Since sea 


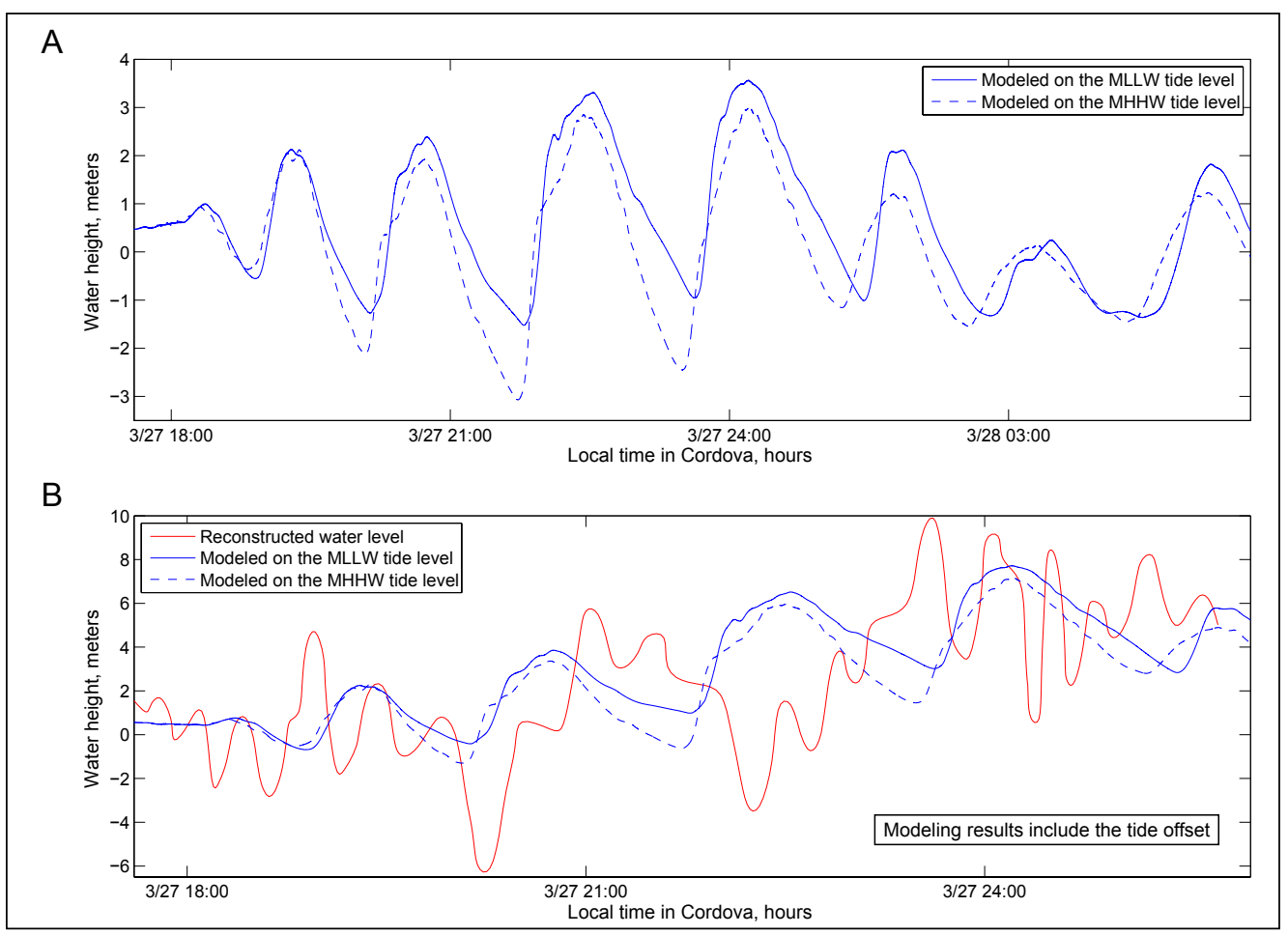

Figure 16. Modeled water level dynamics in Cordova harbor during the 1964 tsunami, based on the JDM. (A) Water level computed under the assumption of constant tide either at the MLLW or at the MHHW level. (B) Tide-corrected simulated water level in Cordova harbor. The inferred marigram for Cordova (see fig. 3 ) is plotted with a red line.

level change due to the astronomic tides is a relatively slow process compared to the rapid sea level variations due to the tsunami, it is possible to decouple these two processes. We thus resort to simulation of the 1964 tsunami without tidal forcing, and then superimpose the computed tsunami with the tide in Cordova. This approach is the so-called 'zero-order approximation' for modeling the 1964 tsunami in Cordova. Refer to Kowalik and others (2006) and Kowalik and Proshutinsky (2010) for a robust discussion of the tsunami-tide interaction. Note that these authors observe a temporal shift in the arrival of waves when modeling the tsunami with and without the tidal component.

Figure 16b shows the simulated water-level dynamics superimposed onto the tide dynamics in the Cordova harbor. The reconstructed water-level dynamics are designated by the red line; the vertical datum in the plot is associated with the post-earthquake MLLW level. The comparison reveals that the simulated waves arrive out of phase with the observations. However, the numerical modeling captures the wave arriving at high tide. We conjecture that a primary reason for the discrepancy between the modeled and observed tsunami dynamics is a distinction between the actual and assumed initial water elevation in Prince William Sound and Gulf of Alaska. For example, according to the JDM, the simulated uplift in Cordova is $0.45 \mathrm{~m}(1.5 \mathrm{ft})$, whereas Cordova was uplifted by $1.8 \mathrm{~m}(6 \mathrm{ft})$ during the 1964 event. Other reasons, such as the difference between the present-day and the 1964 bathymetry as well as exclusion of the tide-tsunami interactions, also contribute to the discrepancy between the modeled and observed water dynamics; however, the error introduced by exclusion of the tide-tsunami interactions is probably less than errors introduced by the JDM model.

To simulate the tsunami dynamics in Tatitlek we analyze observations of the vertical sea-floor deformation in Prince William Sound (by L.R. Mayo, J.B. Case, D.S. McCulloch, M.G. Bonilla, E. Parkin, and U.S. Coast and Geodetic Survey) and reconstruct the initial sea-floor deformation based on the available measurements (Plafker, 1969). Note that the data coverage restricts modeling of the water dynamics near Tatitlek for the first hour after the earthquake, before arrival of waves originating in regions outside of the data coverage. Figure 17 shows the modeled water-level dynamics in the Tatitlek harbor. Recall that during or shortly after the earthquake the residents observed a withdrawal of water and then a $5.2-5.5 \mathrm{~m}(17-18 \mathrm{ft})$ wave. The simulated water dynamics show neither the withdrawal nor a $5 \mathrm{~m}(16.4 \mathrm{ft})$ wave shortly after the earthquake. One of the possible explanations for the observed wave is that it was generated by a large horizontal displacement of the land against the ocean (for example, Plafker, 1969). However, the measured horizontal displacements near Tatitlek Narrows show that the displacement occurred in the southeast direction and was about $6.1-7.6 \mathrm{~m}$ (20-25 ft). Note that the 1964 horizontal displacement seems to be directed along the Narrows and does not directly push water against the northern shore, where the village is located. Moreover, since Tatitlek Narrows is shallow and lacks steep offshore gradients (such as near Chenega, Sawmill Bay, and Whittier), we hypothesize that the horizontal land displace- 


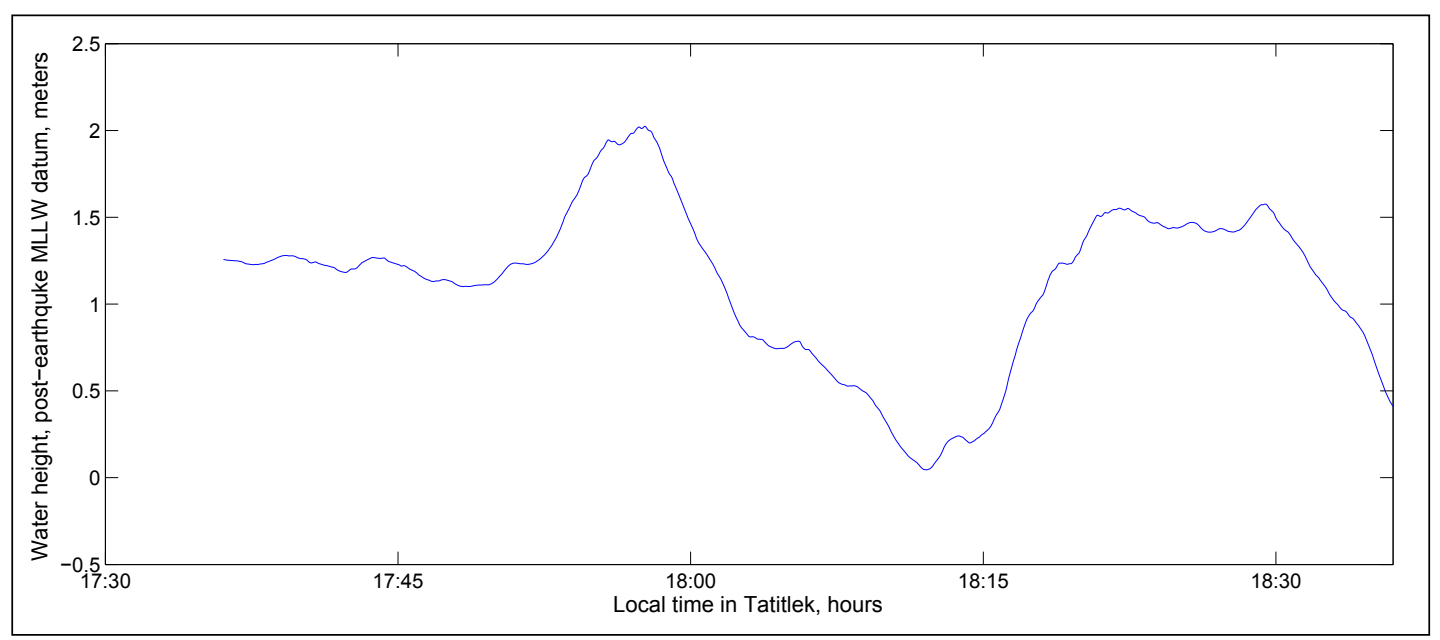

Figure 17. Modeled water-level dynamics in Tatitlek harbor during the 1964 tsunami. Initial seafloor displacement in the Prince William Sound region is an interpolation of data collected by L.R. Mayo, J.B. Case, D.S. McCulloch, M.G. Bonilla, E. Parkin, and U.S. Coast and Geodetic Survey, presented in Plafker (1969, plate 2).

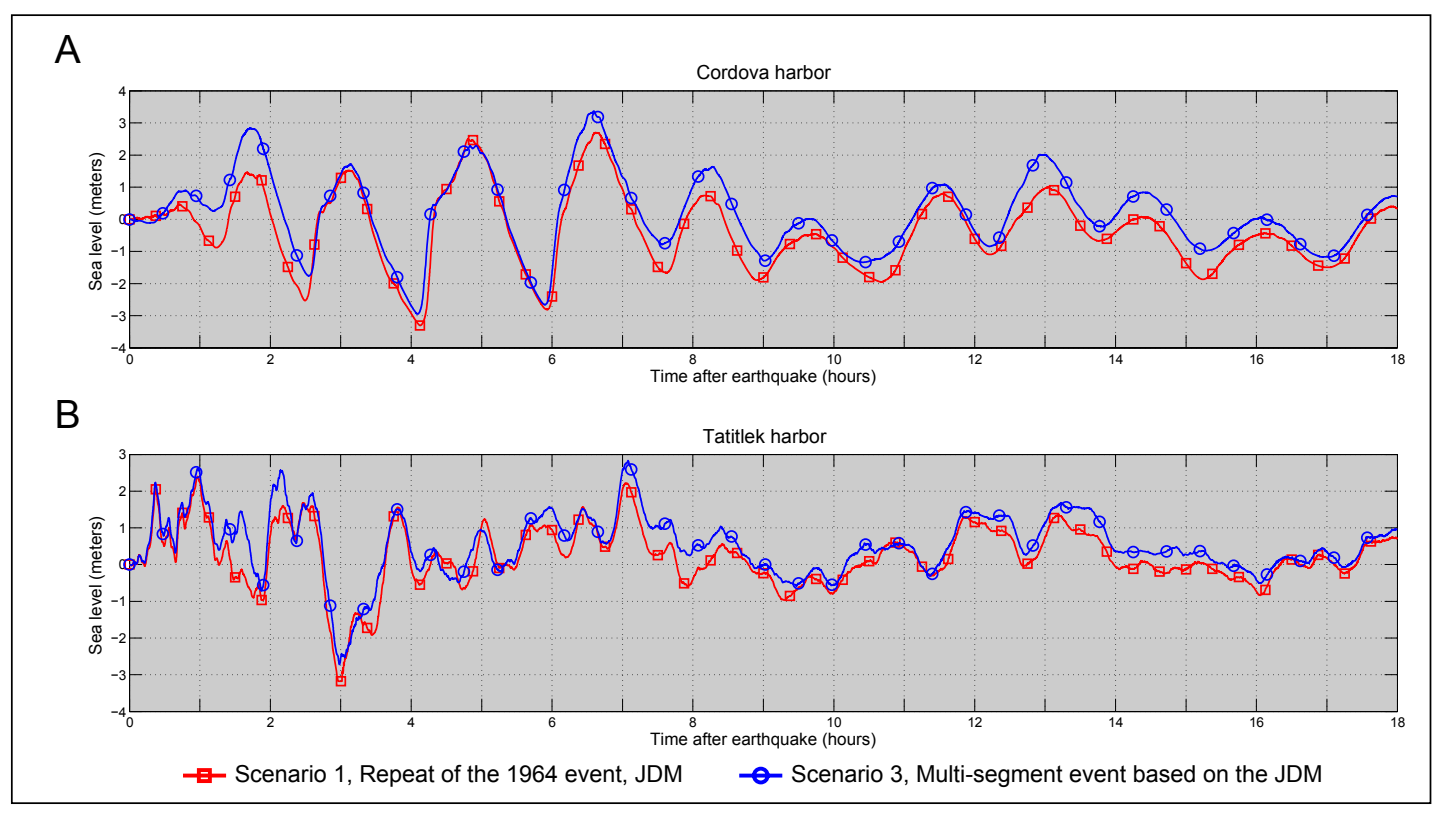

Figure 18. Modeled water-level dynamics in (A) Cordova and (B) Tatitlek according to scenarios 1 and 3.

ments cannot push a significant amount of water against the shore and be a direct cause for the observed $5 \mathrm{~m}$ (16 ft) wave shortly after the earthquake. We emphasize that modeling the 1964 tsunami in both Cordova and Tatitlek is out of the scope of this report. This report is focused on development of a maximum credible tsunami scenario and not on modeling the 1964 tsunami in Cordova and Tatitlek. Understanding the 1964 tsunami at both locations, however, is important because it allows discovery of possible shortcomings in the hydrodynamic modeling techniques. Future research is necessary to fully analyze the discrepancy between the modeled and observed water dynamics.

\section{Results of hypothetical tsunami scenarios}

We performed numerical calculations for all 13 scenarios. The water dynamics are modeled in each grid (listed in table 1), and were used to compute the extent of inundation only in the high-resolution grid. We begin discussion of our modeling results by noting that scenarios 1 and 2 predict a maximum wave of about $3 \mathrm{~m}(\sim 10 \mathrm{ft})$ in the Cordova harbor. Even though scenarios 3 and 4 assume a much greater rupture area, these scenarios also predict an approximately $3 \mathrm{~m}(\sim 10 \mathrm{ft})$ wave in the Cordova harbor. The comparison of the modeled water dynamics in the Cordova and Tatitlek harbors for scenarios 1 and 3 are shown in figures 18a and $18 \mathrm{~b}$. Note that there are four distinct waves, with the largest wave occurring 7 hours after the earthquake. The simulated water dynamics at Tatitlek predict occurrence of erratic waves propagating in the Narrows immediately after the earthquake, with the maximum wave height occurring about 7 hours after the onset of the tsunami. 




Figure 19. Modeled water-level dynamics in (A) Cordova and (B) Tatitlek according to scenarios 5 and 6.

Scenario 5, which models a rupture of the YakutatYakataga segment, predicts a $0.5 \mathrm{~m}(1.6 \mathrm{ft})$ subsidence in Cordova and a maximum wave height of $1.5 \mathrm{~m}(5 \mathrm{ft})$ approximately two hours after the earthquake. Similar modeling results are obtained for the Tatitlek harbor. A rupture of the Cascadia subduction zone, according to scenario 6, predicts a series of waves arriving at Prince William Sound four hours after the earthquake. The modeled water level dynamics for scenarios 5 and 6 in Cordova and Tatitlek harbors are shown in figures $19 \mathrm{a}$ and $19 \mathrm{~b}$. The maximum predicted wave height according to these scenarios does not exceed $2.0 \mathrm{~m}(6.6 \mathrm{ft})$ at either location.

Comparison of the water-level dynamics for all scenarios is shown in appendices A and B, except for the following scenarios. For the sake of clarity we do not show the modeling results for the repeat of the 1964 events (scenarios 1 and 2 ), since these scenarios produce less inundation than the multi-segment events (scenarios 3 and 4). We also decided not to show the results for scenario 4 , since the simulated water dynamics are comparable to the ones modeled by scenario 3 . Moreover, for the sake of brevity we display only the results for the earthquake ruptures based on the slip deficit model, since the latter are similar to the results based on the uniform lateral slip distributions.

Our analyses show that the worst-case scenario for Cordova is scenario 13, which models a $\mathrm{M}_{\mathrm{W}} 8.8$ rupture in Prince William Sound. The maximum wave in the Cordova harbor under this scenario is about $6 \mathrm{~m}$, arriving approximately 1 hour after the earthquake.

The worst-case scenario for Tatitlek is either scenario 12 (a Tohoku-type event in the Gulf of Alaska) or scenario 13. The maximum wave generated under scenario 12 is about $5 \mathrm{~m}$, striking the Tatitlek boat harbor approximately 2.5 hours after the earthquake. Scenario 13 predicts that a $4 \mathrm{~m}$ wave might arrive at Tatitlek in less than an hour.

Figures 20 and 21 show extents of the modeled inundation for all scenarios that produce significant inundation in Cordova and Tatitlek. The potential repeat of the 1964 rupture based on the SDM is omitted for the sake of brevity. After examining the maximum composite inundation for all 13 scenarios in Cordova, on the high-resolution DEM and the aerial photo, we think that the high-resolution DEM might have some discrepancies at the following two locations. The first location is at the intersection of Water Street and Railroad Avenue (marked with orange crossed circles in figure 20 ), while the second location is between the Coast Guard Lane and Industry Road (marked with blue crossed circles). Both locations are adjacent to the steep slopes, and hence while developing the DEM for Cordova, the slope terrain might have crept into low-lying regions. Unfortunately, we do not have GPS measurements at either location. Therefore, we adjust the maximum composite inundation extent and assume that both locations might be flooded as nearby areas. The assumed maximum flow depth at these locations ranges between $0.6-1.0 \mathrm{~m}(2.0-3.3 \mathrm{ft})$. The maximum composite and adjusted flow depth over dry land for Cordova with the associated maximum composite calculated extent of inundation are displayed in Appendix C. The maximum composite flow depths over dry land in Tatitlek are displayed in Appendix D (we do not adjust the maximum composite flow depth in Tatitlek). Note that tsunami flow depth is one of the important indicators of potential damage and must be differentiated from runup height (Synolakis and Bernard, 2006). For reference we indicate values of $0.5 \mathrm{~m}$ (1.6 ft), which approximately corresponds to knee height, and $2 \mathrm{~m}$ ( $6.6 \mathrm{ft}$ ), which is just above the average person's body height. 


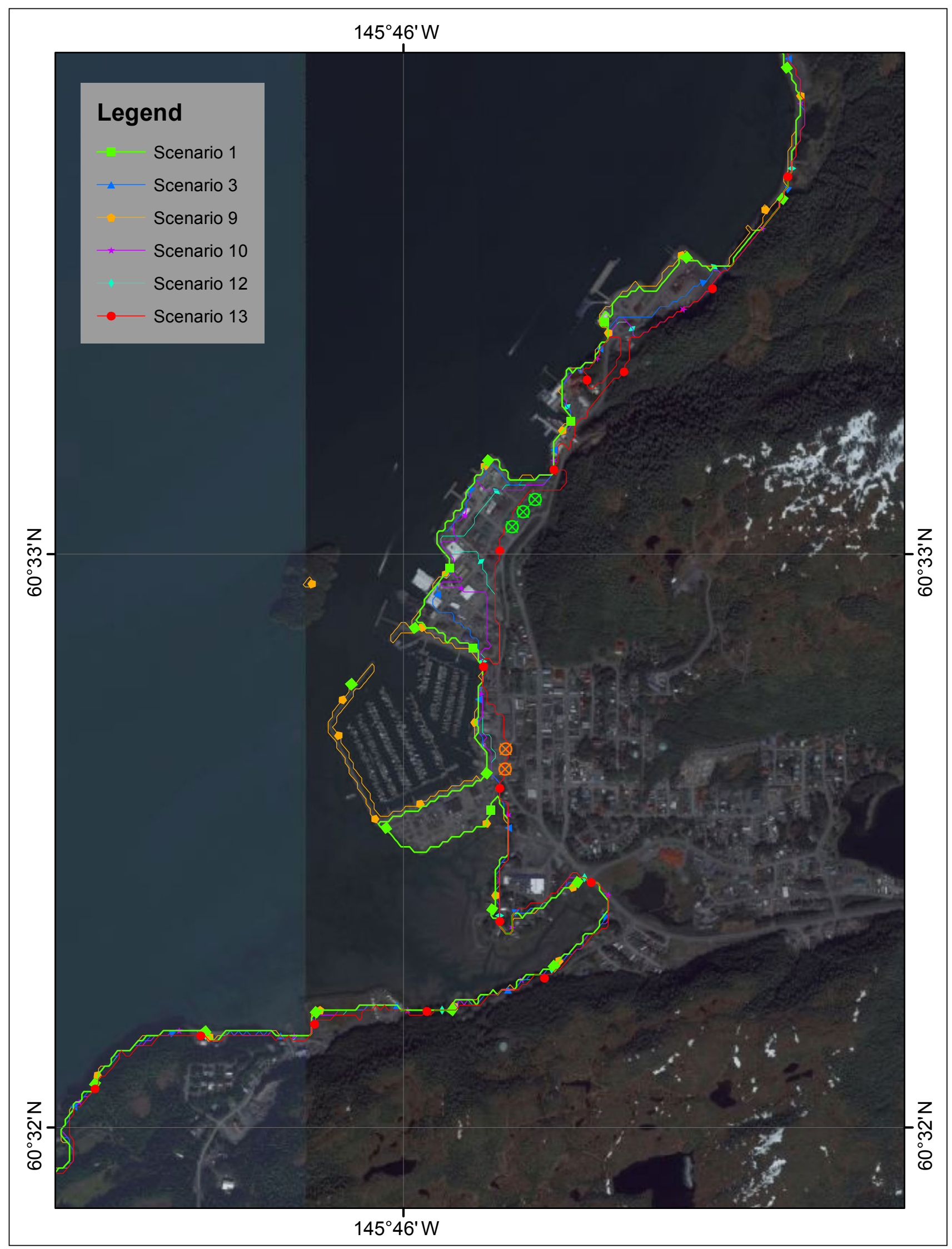

Figure 20. Modeled potential inundation in Cordova by tectonic waves for all scenarios that result in a significant inundation. The DEM corresponds to the present-day MHHW datum. Due to the steep topography, inundation areas for several tsunami scenarios have a common boundary, and the plotted extents of the inundation areas may overlay each other. Locations with large uncertainties in the high-resolution DEM are marked by crossed circles 


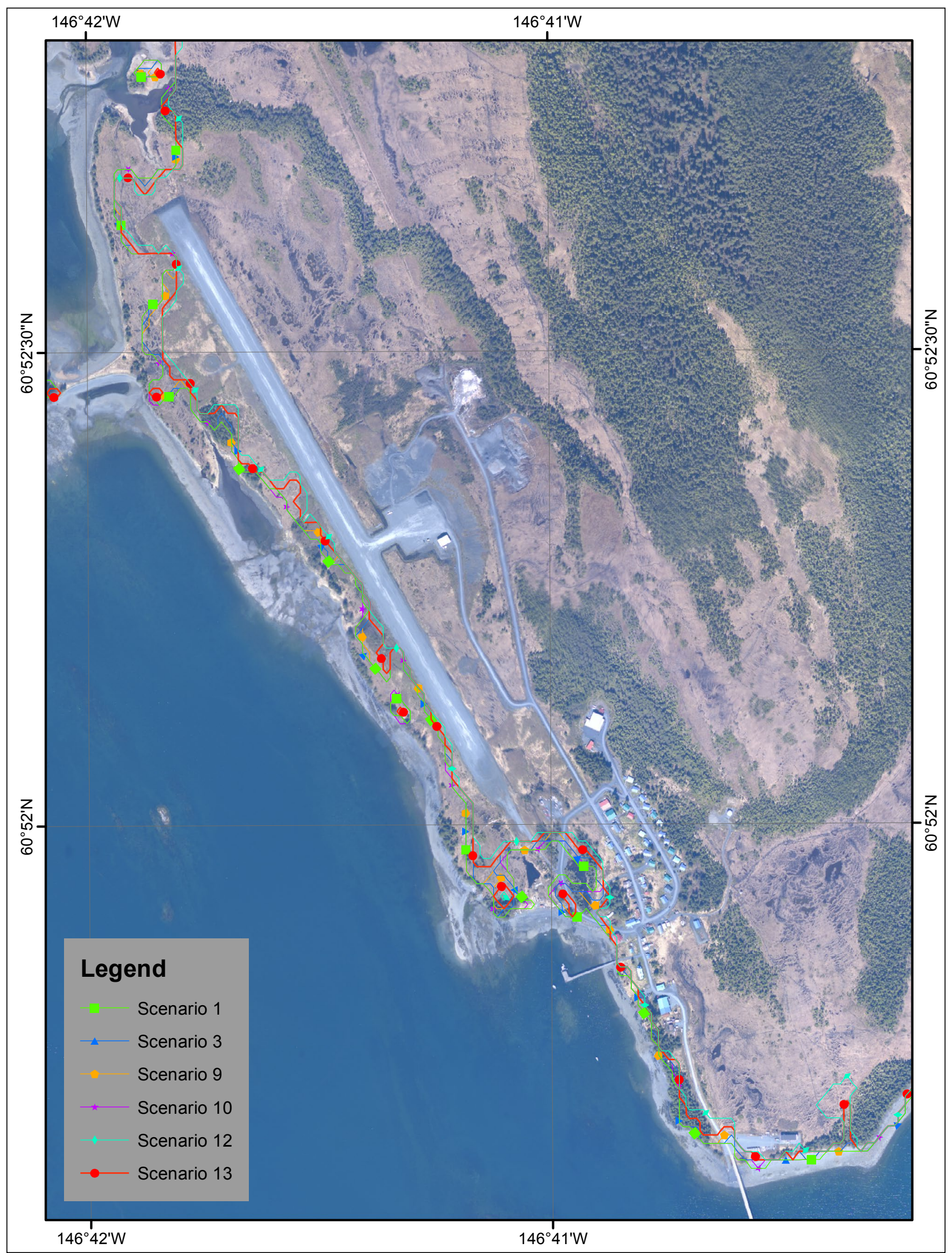

Figure 21. Modeled potential inundation in Tatitlek by tectonic waves for all scenarios that result in a significant inundation.

The DEM corresponds to the present-day MHHW datum. Due to the steep topography, inundation areas for several tsunami scenarios have a common boundary, and the plotted extents of the inundation areas may overlay each other. 


\section{Time series and other numerical results}

To help emergency management personnel assess tsunami hazards in Cordova and Tatitlek, we supplement the inundation maps with the time series of the modeled water level and velocity dynamics at some on-land and some offshore locations in the communities. We plot sea level for each location, represented by a number in appendix A-1 (for Cordova) and appendix B-1 (for Tatitlek). We plot water velocity for Cordova and Tatitlek in appendices A-2 and B-2, respectively. The zero time corresponds to the epicenter origin time, that is, the start of the ground shaking. The elevation of each onshore location corresponds to the post-earthquake MHHW datum, while for post-earthquake offshore locations we use the pre-earthquake datum to show the height of the arriving tsunami waves. The dashed lines show the water level after the tsunami. For example, according to scenario 9, the postearthquake elevation of Point 4 is $0.05 \mathrm{~m}$ below the MHHW sea level. Scenario 12 also predicts that Point 4 is below the MHHW water level after the tsunami. Therefore, we do not provide the elevations for these scenarios, but mark the final water levels by dashed lines. Since velocity magnitude is calculated as water flux divided by water depth, the velocity value can have large uncertainties if the depth is shallow; therefore, in the plots shown the velocity is computed only where water depth is greater than $0.3 \mathrm{~m}(1 \mathrm{ft})$. We note that Point 7 is located at the base of a steep embankment. The numerical modeling reveals that this point is flooded, but the next uphill point remains dry. Since the velocities are computed at the interface between these two points, the displayed velocity is zero.

\section{Sources of errors and uncertainties}

The hydrodynamic model used to calculate propagation and runup of tsunami waves is a nonlinear, flux-formulated, shallow-water model (Nicolsky and others, 2011a) that has passed the validation and verification tests required for models used in production of tsunami inundation maps (Synolakis and others, 2007; NTHMP, 2012). We emphasize that the 1964 tsunami dynamics near Cordova were probably coupled with the ocean tide dynamics in shallow Orca Inlet. The modeled tsunami dynamics do not take into account the tsunami-tide dynamics and thus could possibly underestimate the maximum wave height. The scientific research community has not yet reached a full understanding of possible interactions between tsunamis and tides in shallow inlets. Further, according to the eyewitness accounts of the 1964 tsunami in Cordova, the observed waves were rising up to to $0.15-0.3 \mathrm{~m} / \mathrm{s}(0.5-1 \mathrm{ft} / \mathrm{s})$ (Wilson and Tørum, 1972) and could have been the 'bores' of water propagating through the shallow areas of the inlet. Although the current model is validated to simulate the hypothetical inundation, it does not take into account the wave dispersion and cannot explicitly model origination and development of the bore-like waves. Moreover, a hypothetical rupture of the normal faults in concert with the subduction earthquake might produce some additional short-period waves that can also contribute to formation of bore-like structures. Therefore, the presented numerical modeling results can be used only as a guideline for predicting an actual inundation event.
Because the initial condition for the modeling is determined by the displacement of the ocean bottom, the largest source of error is the earthquake model. When a tsunami is generated in the vicinity of the coast, the direction of the incoming waves, their amplitudes, and times of arrival are determined by the initial displacements of the ocean floor in the source area because the distance to the shore is too small for the waves to dissipate. Therefore, the near-field inundation modeling results are especially sensitive to the fine structure of the tsunami source. The modeling process is highly sensitive to errors when the complexity of the source function is combined with its proximity to the coastal zone.

During development of tsunami inundation maps, a spatially averaged ground subsidence/uplift model is assumed for Cordova and Tatitlek. However, during a potential earthquake, soil compaction in areas of unconsolidated deposits in the coastal area might occur and the extent of the tsunami inundation could be farther landward. Finally, we mention that the horizontal resolution of the grid used for inundation modeling is about $15 \mathrm{~m}$ (49 $\mathrm{ft})$. This scale is mostly limited by the resources necessary to compute the tsunami inundation at higher resolution. The $15 \mathrm{~m} \mathrm{(49} \mathrm{ft)} \mathrm{resolution}$ is high enough to describe major relief features, but small topographic features, buildings, and other facilities cannot be resolved accurately by the existing model.

\section{SUMMARY}

We present the results of numerical modeling of earthquake-generated tsunamis for Cordova and Tatitlek, Alaska. Hypothetical scenario 13, a $\mathrm{M}_{\mathrm{w}} 8.8$ rupture in Prince William Sound, and hypothetical scenario 12, a Tohoku-type event in the Gulf of Alaska, result in the "worst case" tsunami inundation hazards for Cordova and Tatitlek, respectively. According to scenario 13, the maximum wave expected in the Cordova harbor is about $6 \mathrm{~m}$, arriving approximately 1 hour after the earthquake. According to scenario 12, the maximum wave generated is about $5 \mathrm{~m}$, striking the Tatitlek boat harbor approximately 2.5 hours after the earthquake. Scenario 13 reveals that a $4 \mathrm{~m}$ wave might arrive at Tatitlek in less than an hour. We emphasize that each of the scenarios considered are geologically reasonable and present potential hazards to each community. The maps showing the results of our modeling have been completed using the best information available and are believed to be accurate; however, their preparation required many assumptions. We considered several tectonic scenarios and provide an estimate of maximum credible tsunami inundation. Actual conditions during a tsunami event may vary from those considered, so the accuracy cannot be guaranteed. The limits of inundation shown should be used only as a guideline for emergency planning and response action. Actual areas inundated will depend on specifics of the earth deformations, land construction, and tide level, and they may differ from areas shown on the map. The information on this map is intended to assist state and local agencies in planning emergency evacuation and tsunami response actions in the event of a major tsunamigenic earthquake. These results are not intended for land-use regulation or building code development. 


\section{ACKNOWLEDGMENTS}

This project was supported by the National Oceanic and Atmospheric Administration (NOAA) under Reimbursable Service Agreement ADN 0931000 with the State of Alaska's Division of Homeland Security and Emergency Management (a division of the Department of Military and Veterans Affairs). Some of the research in this publication is sponsored by the Cooperative Institute for Alaska Research with funds from NOAA under cooperative agreement NA08OAR4320751 with the University of Alaska Fairbanks. Numerical calculations for this work were supported by a grant of High Performance Computing (HPC) resources from the Arctic Region Supercomputing Center (ARSC) at the University of Alaska Fairbanks. We thank Ronni Grapenthin and William Witte for their help with the RTK GPS survey in Cordova and Tatitlek. We also express our gratitude to Julie Elliot for her help in assessing potential earthquakes in the Yakutat block, and for sharing her data with us. Lee Liberty and Shaun Finn provided information on normal faults in Prince William Sound. Natalia Ruppert and Rod Combellick provided valuable contributions to discussions on crustal and subduction-type tsunamigenic earthquakes, and Ian Dickson proofread the manuscript. Insightful reviews by Liujuan (Rachel) Tang and Breanyn MacInnes helped improve this report.

\section{REFERENCES CITED}

Atwater, B.F., 1987, Evidence for great Holocene earthquakes along the outer coast of Washington state: Science, v. 236, p. 942-944.

Atwater, B.F., Musumi-Rokkaku, Satoku, Satake, Kenji, Tsuji, Yoshinobu, Ueda, Kazue, and Yamaguchi, D.K., 2005, The orphan tsunami of 1700-Japanese clues to a parent earthquake in North America: U.S. Geological Survey Professional Paper 1707 (prepared in cooperation with the Geological Survey of Japan, the University of Tokyo, and the University of Washington, and published in association with University of Washington Press), $133 \mathrm{p}$.

Balay, S., Brown, J., Buschelman, K., Eijkhout, V., Gropp, W., Kaushik, D., Knepley, M., Curfman McInnes, L., Smith, B., and Zhang, H., 2012, PETSc Users Manual ANL-95/11, Revision 3.3: Argonne, IL, Argonne National Laboratory, Mathematics and Computer Science Division, 211 p., http://www.mcs.anl.gov/petsc/petsc-3.3/docs/ manual.pdf.

Byrne, D.E., Davis, D.M., and Sykes, L.R., 1988, Loci and maximum size of thrust earthquakes and the mechanics of the shallow region of subduction zones: Tectonics, v. 7 , no. 4 , p. $833-857$.

Caldwell, R.J., Eakins, B.W., and Lim, E., 2009, Digital elevation models of Prince William Sound, Alaska-Procedures, data sources and analysis: Boulder, Colorado, National Geophysical Data Center, NOAA, 43 p., www.ngdc.noaa. gov/dem/report/download/1305.

Carver, G.A., and Plafker, George, 2008, Paleoseismicity and neotectonics of the Aleutian subduction zone-An overview, in Freymueller, J.T., Haeussler, P.J., Wesson, R.L, and Ekström, G., eds., Active tectonics and seismic potential of Alaska: American Geophysical Union Geophysical Monograph 179, p. 43-63.
Chance, J., 1972, Perceptions of earthquake-related physical events in coastal communities, appendix-Summary and recommendations, in The Great Alaska Earthquake of 1964: Washington, D.C., National Academy of Sciences-Engineering, p. 117-136.

Christensen, D.H., and Beck, S.L., 1994, The rupture process and tectonic implications of the Great 1964 Prince William Sound Earthquake: Pure and Applied Geophysics, v. 142, no. 1 , p. 29-53.

Christensen, D.H., and Ruff, L.J., 1988, Seismic coupling and outer rise earthquakes: Journal of Geophysical Research, v. 93, no. B11, p. 13,421-13,444, doi:10.1029/ JB093iB11p13421.

Coulter, H.W., and Migliaccio, R.R., 1966, Effects of the earthquake of March 27, 1964 at Valdez, Alaska: U.S. Geological Survey Professional Paper, 542-C, 36 p.

Douglass, W.C., 1964, A history of the Kennecott Mines, Kennecott, Alaska: Alaska Division of Mines and Minerals Miscellaneous Publication 21, 26 p, doi:10.14509/723.

Elliott, Julie, 2011, Active tectonics in southern Alaska and the role of the Yakutat block constrained by GPS measurements: Fairbanks, Alaska, Ph.D. Dissertation, University of Alaska Fairbanks, 187 p.

Finn, S.P., 2012, Megathrust splay fault geometry in Prince William Sound, Alaska: Boise, Idaho, Boise State University, Ph.D. Dissertation, 169 p.

Freund, L.B., and Barnett, D.M., 1976, A two-dimensional analysis of surface deformation due to dip-slip faulting: Bulletin of the Seismological Society of America, v. 66, p. 667-675.

Freymueller, J.T., Woodard, H., Cohen, S., Cross, R., Elliott, J., Larsen, C., Hreinsdottir, S., and Zweck, C., 2008, Active deformation processes in Alaska, based on 15 years of GPS measurements, in Freymueller, J.T., Haeussler, P.J., Wesson, R., and Ekstrom, G., eds., Active Tectonics and Seismic Potential of Alaska: Washington, D.C., American Geophysical Union Geophysical Monograph, 179, p. 1-42., doi:10.1029/179GM02.

Fujii, Yushiro, Satake, Kenji, Sakai, Shin'ichi, Shinohara, Masanao, and Kanazawa, Toshihiko, 2011, Tsunami source of the 2011 off-the-Pacific-coast-of-Tohoku Earthquake: Earth, Planets, Space, v. 63, no. 7, p. 815-820, http://www.terrapub.co.jp/journals/EPS/ pdf/2011/6307/63070815.pdf.

Geist, E.L., and Dmowska, R., 1999, Local tsunamis and distributed slip at the source: Pure and Applied Geophysics, v. 154, p. 485-512.

Goto, C., Ogawa, Y., Shuto, N., and Imamura, F., 1997, Numerical method of tsunami simulation with the leap-frog scheme: UNESCO, IUGG/IOC TIME Project, Manuals and Guides, no. 35.

Gusman A.R., Tanioka, Y., Matsumoto, Hiroyuki, and Iwasaki, S.-I., 2009, Analysis of the tsunami generated by the great 1977 Sumba earthquake that occurred in Indonesia: Bulletin of the Seismological Society of America, v. 99, no. 4, p. 2,169-2,179, doi: 10.1785/0120080324

Hamilton, Sarah, and Shennan, Ian, 2005, Late Holocene great earthquakes and relative sea-level change at Kenai, southern Alaska: Journal of Quaternary Science, v. 20, no. 2, p. 95-111. 
Hampton, M.A., Lee, H.J., and Locat, Jacques, 1996, Submarine landslides: Reviews of Geophysics, v. 34, no. 1, p. 33-59.

Holdahl, S.R., and Sauber, Jeanne, 1994, Coseismic slip in the 1964 Prince William Sound earthquake-A new geodetic inversion: Pure and Applied Geophysics, v. 142, no. 1, p. 55-82.

Ichinose, Gene, Somerville, Paul, Thio, H.K., Graves, Robert, and O'Connell, Dan, 2007, Rupture process of the 1964 Prince William Sound, Alaska, earthquake from the combined inversion of seismic, tsunami, and geodetic data: Journal of Geophysical Research, v. 112, no. B07, p. 306, 21 p., doi:10.1029/2006JB004728.

Johnson, J.M., Satake, Kenji, Holdahl, S.R., and Sauber, Jeanne, 1996, The 1964 Prince William Sound earthquake-Joint inversion of tsunami waveforms and geodetic data: Journal of Geophysical Research, v. 101, no. B1, p. 523-532.

Kanamori, Hiroo, 1971,Seismological evidence for a lithospheric normal faulting - The Sanriku earthquake of 1933: Physics of the Earth \& Planetary Interiors, v. 4, p. 289-300.

Kowalik, Zygmunt, and Proshutinsky, Andrey, 2010, Tsunamitide interactions-A Cook Inlet case study: Continental Shelf Research, v. 30, p. 633-642.

Kowalik, Zygmunt, Proshutinsky, Tatiana, and Proshutinsky, Andrey, 2006, Tide-Tsunami Interactions: Science of Tsunami Hazards, v. 24, no. 4, p. 242-256.

Kulikov, E.A., Rabinovich, A.B., Fine, I.V., Bornhold, B.D., and Thomson, R.E., 1998, Tsunami generation by landslides at the Pacific coast of North America and the role of tides: Oceanology, v. 38, no. 3, p. 323-328.

Lander, J.F., 1996, Tsunamis affecting Alaska, 1737-1996: Boulder, Colorado, National Geophysical Data Center (NGDC), NOAA, Key to Geophysical Research Documentation, v. 31, 195 p.

Leica Geosystem AG, 2002, GPS User manual, Version 4, Leica Geosystems AG, Heerbrugg, Switzerland, 62 p.

Lim, E., Eakins, B.W., and Wigley, R., 2009, Southern Alaska coastal relief model-Procedures, data sources, and analysis: National Geophysical Data Center, NOAA, 25 p., http://www.ngdc.noaa.gov/mgg/coastal/s_alaska.html

Miller, D.J., 1960, Giant waves in Lituya Bay, Alaska: U.S. Geological Survey Professional Paper 354-C, p. 51-86, 1 sheet, scale 1:50,000.

Moss, Robb E.S., and Travasarou, Thaleia, 2006, Tsunamigenic probabilistic fault displacement hazard analysis for subduction zones-Proceedings of the 8th U.S. National Conference on Earthquake Engineering: Earthquake Engineering Research Institute, Paper 238, 9 p.

National Tsunami Hazard Mapping Program (NTHMP), 2010, Guidelines and best practices for tsunami inundation modeling for evacuation planning: NTHMP Mapping \& Modeling Subcommittee, NOAA.

National Tsunami Hazard Mapping Program (NTHMP), 2012, Proceedings and Results of The 2011 NTHMP Model Benchmarking Workshop, Boulder: U.S. Department of Commerce/NOAA/NTHMP; (NOAA Special Report). 436 p. (available at http://nthmp.tsunami.gov)
Nicolsky, D.J., 2012, Alaska tsunami model, in Proceedings and Results of the 2011 NTHMP Model Benchmarking Workshop: Boulder, CO, U.S. Department of Commerce/ NOAA/NTHMP, NOAA Special Report, p. 55-87 (available at http://nthmp.tsunami.gov).

Nicolsky, D.J., Suleimani, E.N., and Hansen, R.A., 2011a, Validation and verification of a numerical model for tsunami propagation and runup: Pure and Applied Geophysics, v. 168, p. 1,199-1,222, doi:10.1007/s00024-010-0231-9.

Nicolsky, D.J., Suleimani, E.N., Combellick, R.A., and Hansen, R.A., 2011b, Tsunami inundation maps of Whittier and western Passage Canal, Alaska: Alaska Division of Geological \& Geophysical Surveys Report of Investigation 2011-7, 65 p.

Nicolsky, D.J., Wolken, G.J., Combellick, R.A., and Hansen, E., 2011c, APPENDIX B: Potential rockfall-generated tsunami at Whittier, Alaska, in Nicolsky, D.J., Suleimani, E.N., Combellick, R.A., and Hansen, R.A., Tsunami inundation maps of Whittier and western Passage Canal, Alaska: Alaska Division of Geological \& Geophysical Surveys Report of Investigation 2011-7A, p. 57-65.

Nicolsky D.J., Suleimani, E.N., Haeussler, P.J., Ryan, H.F., Combellick, R.A., Koehler, R.D., and Hansen, R.A., 2013, Tsunami inundation maps of Port Valdez, Alaska: Alaska Division of Geological \& Geophysical Surveys Report of Investigations 2013-1, 79 p.

Nishenko, S.P., 1991, Circum-Pacific seismic potential, 19891999: Pure and Applied Geophysics, v. 135, p. 169-259.

Nishenko, S.P., and Jacob, K.H., 1990, Seismic potential of the Queen Charlotte-Alaska-Aleutian seismic zone: Journal of Geophysical Research, v. 95, no. B3, p. 2,511-2,532.

Ohta, Yusaku, Freymueller, J.T., Hreinsdottir, Sigrun, and Suito, Hisashi, 2006, A large slow slip event and the depth of the seismogenic zone in the south-central Alaska subduction zone: Earth \& Planetary Science Letters, v. 247, p. 108-116, doi:10.1016/j.epsl.2006.05.013.

Okada, Yoshimitsu, 1985, Surface deformation due to shear and tensile faults in a half-space: Bulletin of the Seismological Society of America, v. 75, no. 4, p. 1,135-1,154.

Okuda, Hiroshi, Nakajima, Kengo, Iizuka, Mikio, Chen, Li, and Nakamura, Hisashi, 2003, Parallel finite element analysis platform for the Earth Simulator-GeoFEM, in Sloot, P.M.A., Abramson, D., Bogdanov, A.V., Dongarra, J.J., Zomaya, A.Y., and Gorbachev, Y.E., eds., Proceedings of the 3rd International Conference on Computational Science Workshop on Computational Earthquake Physics and Solid Earth System Simulation, June 2-4, 2003, volume III: Melbourne, Australia, Springer, p. 773-780.

Papazachos, B.C., Scordilis, E.M., Panagiotopoulos, D.G., Papazachos, C.B., and Karakaisis, G.F., 2004, Global relations between seismic fault parameters and moment magnitude of earthquakes: Bulletin of the Geological Society of Greece, v. 36 , p. $1,482-1,489$.

Plafker, George, 1967, Surface faults on Montague Island associated with the 1964 Alaska earthquake: U.S. Geological Survey Professional Paper 543-G, p. G1-G42.

1969, Tectonics: U.S. Geological Survey Professional Paper 543-I, p. G1-G74. 
Plafker, George, and Thatcher, Wayne, 2008, Geological and geophysical evaluation of the mechanisms of the Great 1899 Yakutat Bay Earthquakes, in Freymueller, J.T., Haeussler, P.J., Wesson, R.L., and Ekström, Goran, eds., Active tectonics and seismic potential of Alaska: Geophysical Monograph Series, v. 179, p. 215-236, ISBN 978-0-87590444-3, doi 10.1029/179GM12, AGU code GM1794443.

Plafker, George, Kachadoorian, Reuben, Eckel, E.B., and Mayo, L.R., 1969, Effects of the earthquake of March 27, 1964, on various communities: U.S. Geological Survey Professional Paper 542-G, $50 \mathrm{p}$.

Priest, G.R., Goldfinger, Chris, Wang, Kelin, Witter, R.C., Zhang, Yinglong, and Baptista, A.M., 2009, Confidence levels for tsunami-inundation limits in northern Oregon inferred from a 10,000-year history of great earthquakes at the Cascadia subduction zone: Natural Hazards, v. 54, no. 1, doi10.1007/s11069-009-9453-5.

Santini, S., Dragoni, M., and Spada, G., 2003, Asperity distribution of the 1964 Great Alaska Earthquake and its relation to subsequent seismicity in the region: Tectonophysics, $\mathrm{v}$. 367, no. 3-4, p. 219-233.

Satake, Kenji, Shimazaki, Kunihiko, Tsuji, Yoshinobu, and Ueda, Kazue, 1996, Time and size of a giant earthquake in Cascadia inferred from Japanese tsunami records of January 1700: Nature, v. 379, no. 6562, p. 246-249.

Satake, Kenji, Wang, Kelin, and Atwater, B.F., 2003, Fault slip and seismic moment of the 1700 Cascadia earthquake inferred from Japanese tsunami descriptions: Journal of Geophysical Research, v. 108, no. B11, p. 2,535-2,551, doi:10.1029/2003JB002521.

Shao, Guangfu, Li, Xiangyu, Ji, Chen, and Maeda, Takahiro, 2011, Focal mechanism and slip history of the $2011 \mathrm{M}_{\mathrm{w}} 9.1$ off the Pacific coast of Tohoku Earthquake, constrained with teleseismic body and surface waves: Earth, Planets, Space, v. 63, no. 7, p. 559-564.

Shennan, Ian, Barlow, Natasha, and Combellick, R.A., 2008, Paleoseismological records of multiple great earthquakes in south-central Alaska-A 4,000-year record at Girdwood, in Freymueller, J.T., Haeussler, P.J., Wesson, R.L, and Ekström, G., eds., Active Tectonics and Seismic Potential of Alaska: American Geophysical Union Geophysical Monograph 179, p. 185-199.

Shennan, Ian, Bruhn, Ronald, and Plafker, George, 2009, Multi-segment earthquakes and tsunami potential of the Aleutian megathrust: Quaternary Science Reviews, v. 28, no. $1-2$, p. 7-13.

Shennan, I., Barlow, N., Pierre, K., Stuart-Taylor, O., and Sea Level Research Unit, Department of Geography, Durham University, 2012, Diatom stratigraphy of Borehole TA8, Portage, Alaska: Alaska Division of Geological \& Geophysical Surveys Geologic Materials Center Data Report 404, $26 \mathrm{p}$.

Sobolev, S.V., Babeyko, A.Y., Wang, R., Hoechner, A., Galas, R., Rothacher, M., Sein, D.V., Schröter, J., Lauterjung, J., and Subarya, C., 2007, Tsunami early warning using GPSShield arrays: Journal of Geophysical Research, v. 112, no. B08, p. 415, doi:10.1029/2006JB004640.
Stauder, William, 1968, Tensional character of earthquake foci beneath the Aleutian Trench with relation to sea-floor spreading: Journal of Geophysical Research, v. 73, no. 24, p. 7,693-7,701, doi:10.1029/JB073i024p07693.

Suito, Hisashi, and Freymueller, J.T., 2009, A viscoelastic and afterslip postseismic deformation model for the 1964 Alaska earthquake: Journal of Geophysical Research, v. 114, no. B11, p. 404-426, doi:10.1029/2008JB005954.

Suleimani, E.N., Combellick, R.A., Marriott, Duncan, Hansen, R.A., Venturato, A.J., and Newman, J.C., 2005, Tsunami hazard maps of the Homer and Seldovia areas, Alaska: Alaska Division of Geological \& Geophysical Surveys Report of Investigation 2005-2, 28 p., 2 sheets, scale 1:12,500.

Suleimani, E.N., Hansen, R.A., Combellick, R.A., Carver, G.A., Kamphaus, R.A., Newman, J.C., and Venturato, A.J, 2002, Tsunami hazard maps of the Kodiak area, Alaska: Alaska Division of Geological \& Geophysical Surveys Report of Investigation 2002-1, 16 p., 4 sheets, scale 1:12,500.

Synolakis, C.E., and Bernard, E.N., 2006, Tsunami science before and beyond Boxing Day 2004, in Thompson, J.M.T., Heppert, H.E., and Sparks, R.S.J., eds., Extreme Natural Hazards: Philosophical Transactions of the Royal Society, Mathematical, Physical, and Engineering Sciences, v. 364, no. 1845 , p. $2,231-2,265$.

Synolakis, C.E., Bernard, E.N., Titov, V.V., Kânoğlu, U., and González, F.I., 2007, Standards, criteria, and procedures for NOAA evaluation of tsunami numerical models: Seattle, Washington, NOAA/Pacific Marine Environmental Laboratory, Technical Memorandum OAR PMEL-135, 55 p.

Titov, V.V., and Synolakis, C.E., 1995, Evolution and runup of breaking and nonbreaking waves using VTSC-2: Journal of Waterway, Port, Coastal and Ocean Engineering, v. 121, no. 6 , p. 308-316.

1997, Extreme inundation flows during the HokkaidoNansei-Oki Tsunami. Geophysical Research Letters, v. 24, no. $11, \mathrm{p}, 1,315-1,318$.

Wang, Kelin, Wells, R.E., Mazzotti, Stephane, Hyndman, R.D., and Sagiya, Takeshi, 2003, A revised dislocation model of interseismic deformation of the Cascadia subduction zone: Journal of Geophysical Research, v. 108, no. B1, p. 2,026-2,038, doi:10.1029/2001JB001227, http://www. agu.org/pubs/crossref/2003/2001JB001227.shtml.

Wilson, B.W., and Tørum, Alf, 1972, Effects of the tsunamisAn engineering study, in The Great Alaska Earthquake of 1964: Washington, DC, United States, National Academy of Sciences-Engineering, p. 361-526.

Witter, R.C., Zhang, Y., Wang, K., Priest, G.R., Goldfinger, C., Stimely, L.L., English, J.T. and Ferro, P.A., 2011, Simulating tsunami inundation at Bandon, Coos County, Oregon, using hypothetical Cascadia and Alaska earthquake scenarios: Oregon Department of Geology and Mineral Industries Special Paper 43, $57 \mathrm{p}$.

Zweck, C., Freymueller, J.T., and Cohen, S.C., 2002, Threedimensional elastic dislocation modeling of the postseismic response to the 1964 Alaska earthquake: Journal of Geophysical Research, v. 107, no B4, p. ECV1-1-ECV1-11, doi: 10.1029/2001JB000409. 


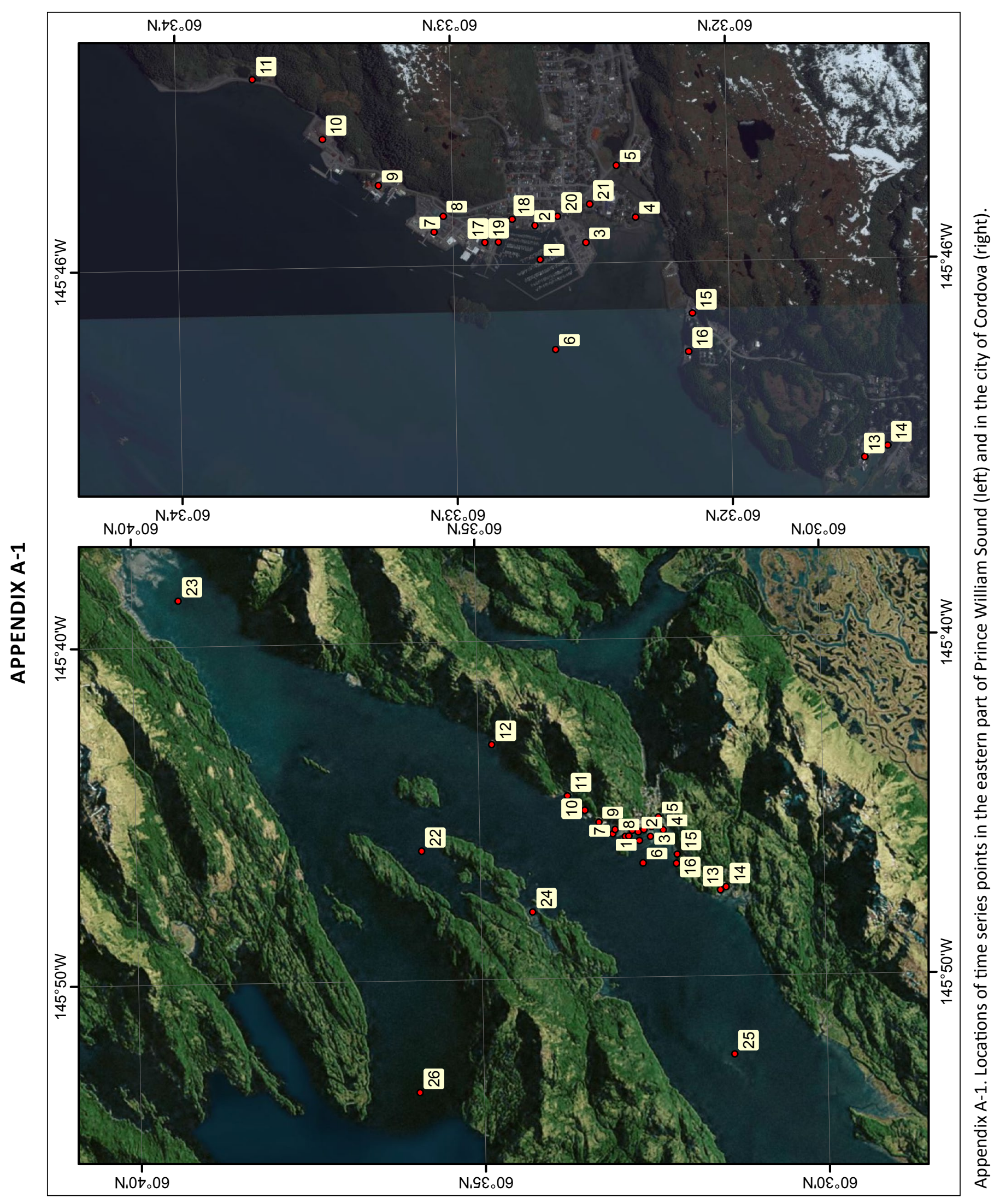




\section{APPENDIX A-2}

Time series of water level and velocity at selected locations in Cordova for scenarios 3, 9, 10,12, and 13. Elevations of onshore locations (left column) correspond to post-earthquake MHHW datum. For offshore locations (right column), in order to show the height of an arriving tsunami, the vertical datum is such that zero corresponds to the pre-earthquake sea level.
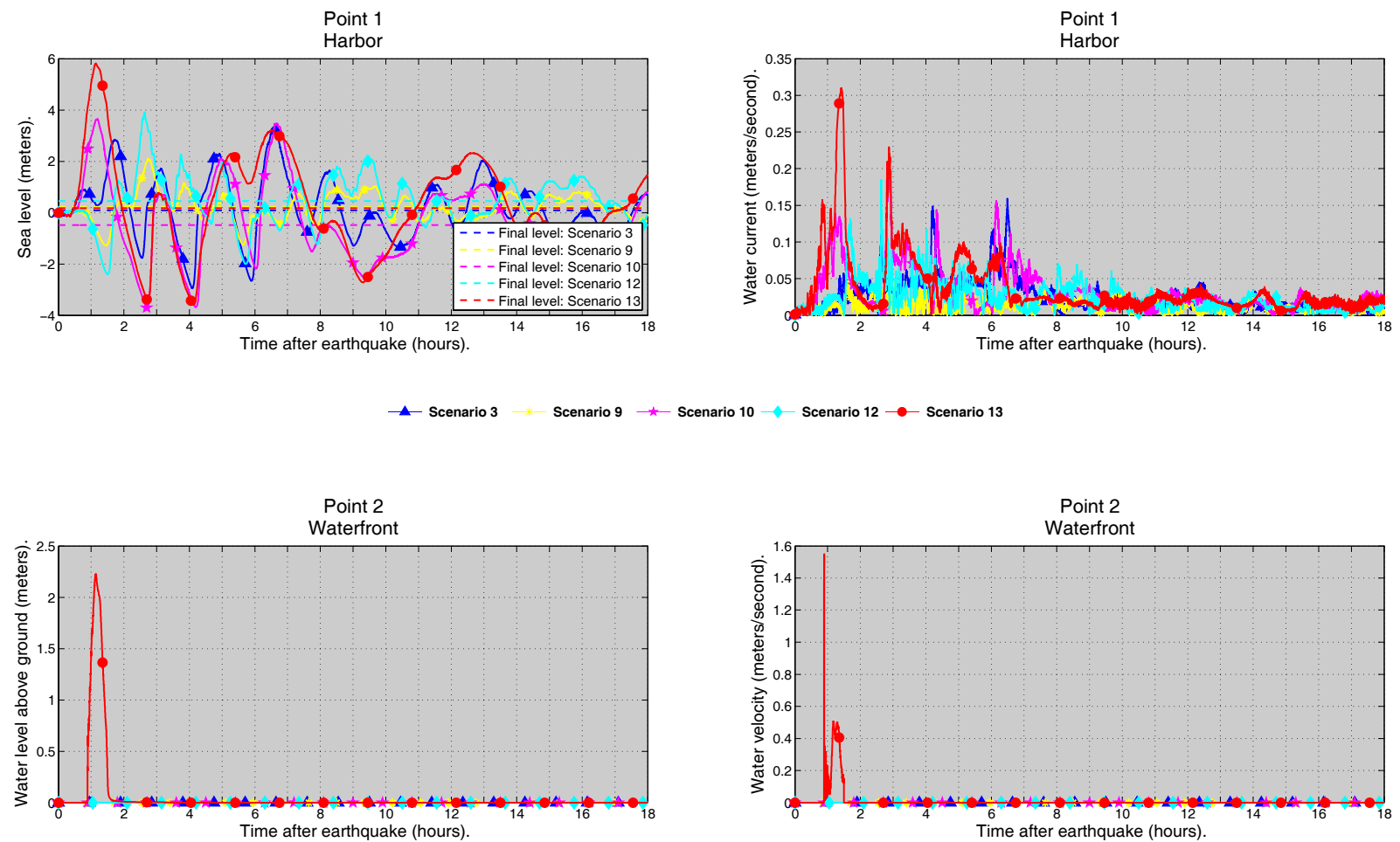

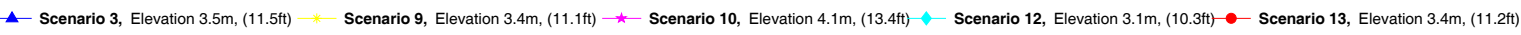
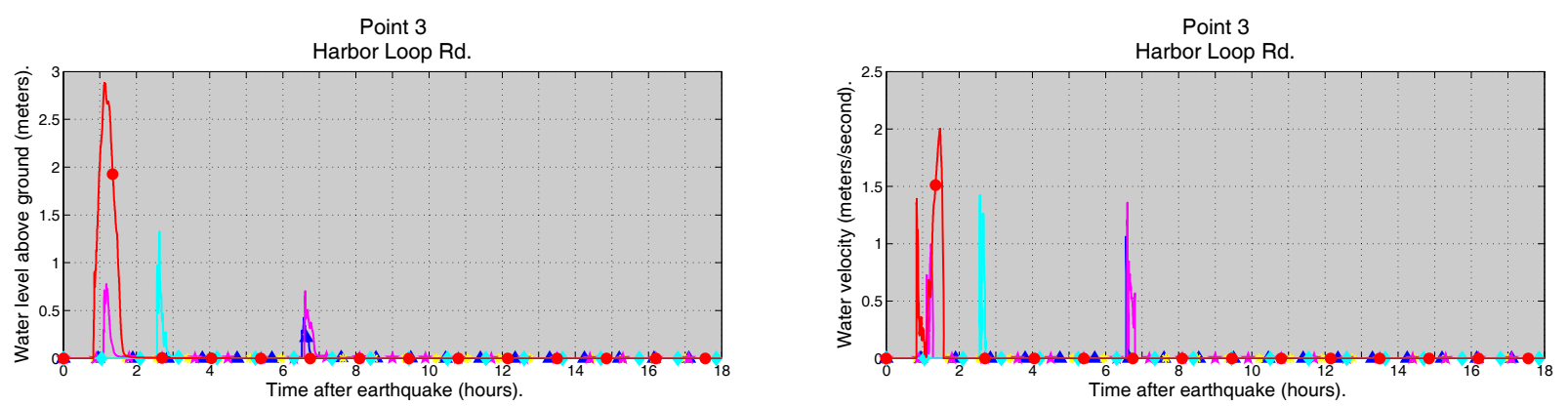

$\_$Scenario 3, Elevation 2.9m, (9.6ft)

Scenario 9, Elevation 2.8m, (9.1ft) $\rightarrow$ * Scenario 10, Elevation 3.5m, (11.4ft) - Scenario 12, Elevation $2.5 \mathrm{~m},(8.3 \mathrm{ft}) \rightarrow-$

Scenario 13, Elevation 2.8m, (9.3ft)
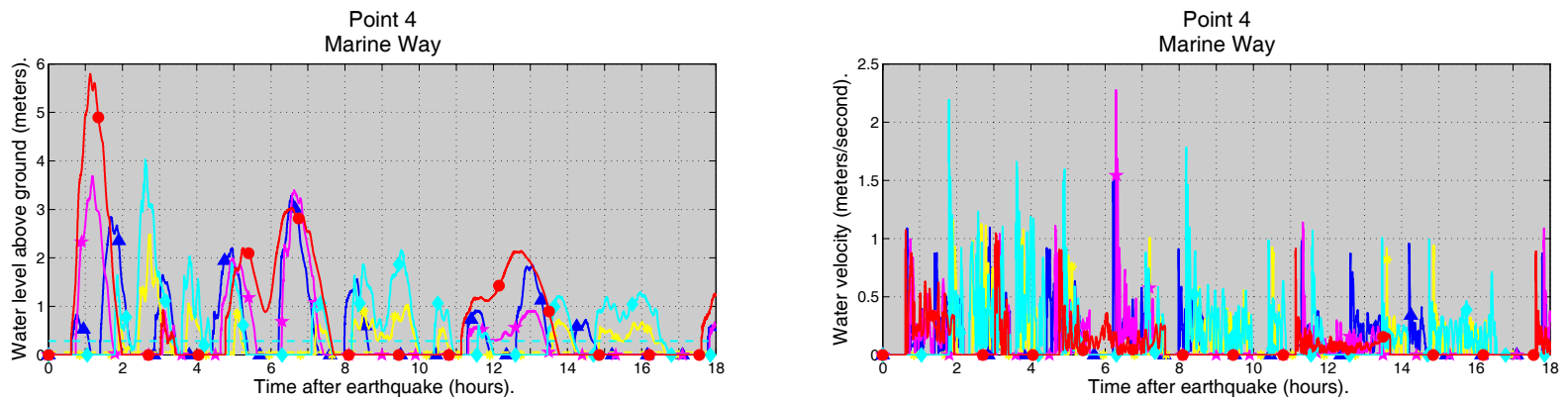


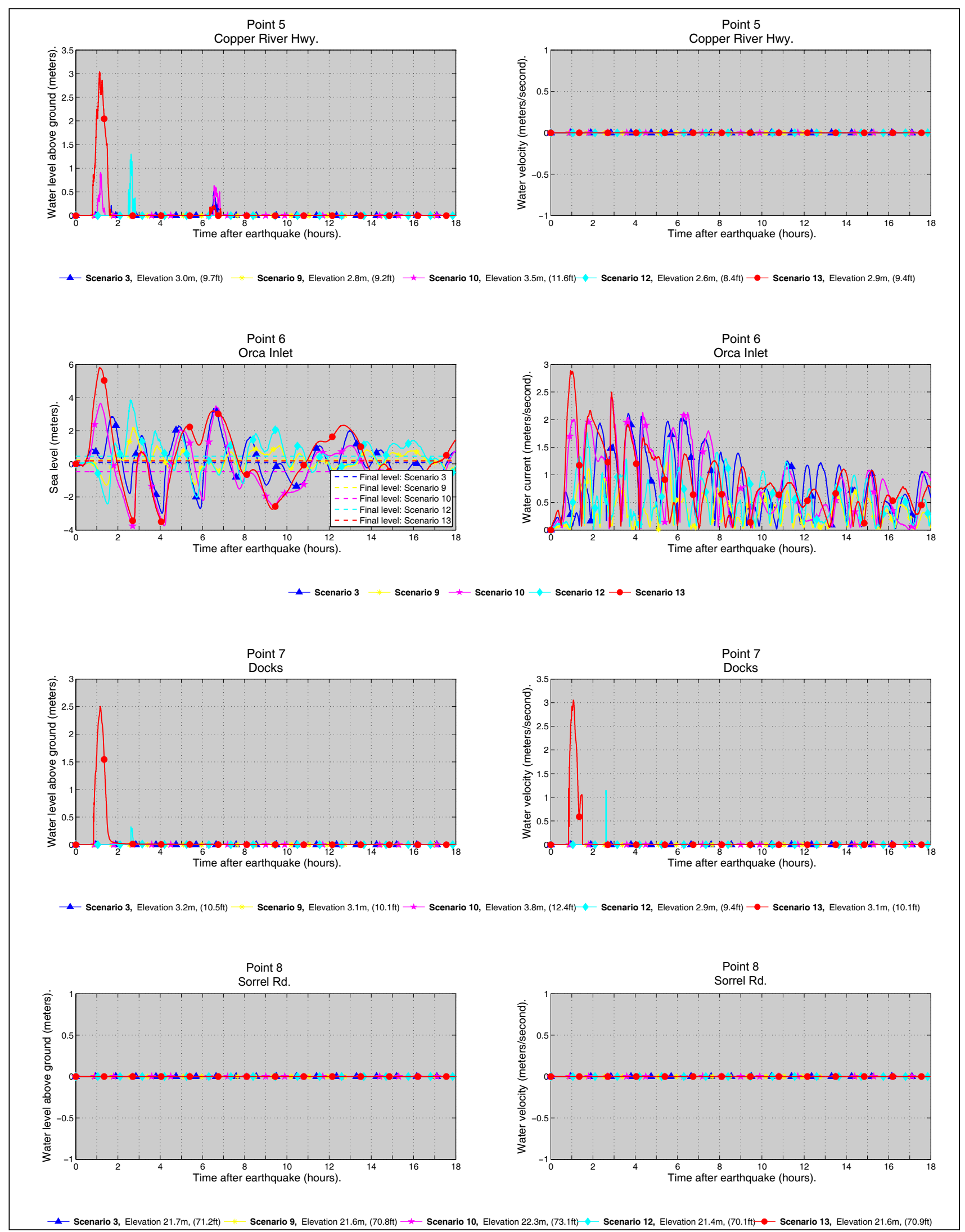




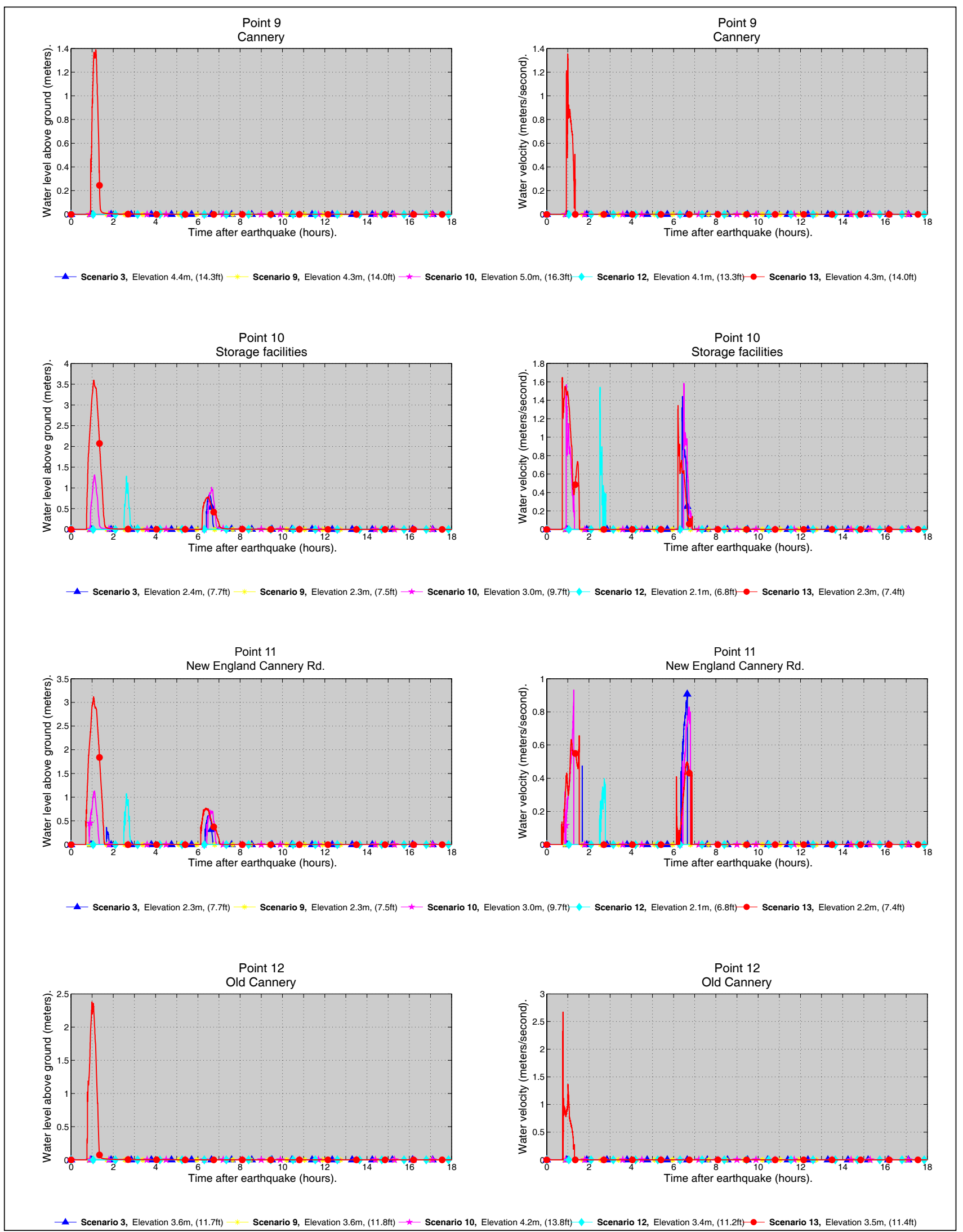









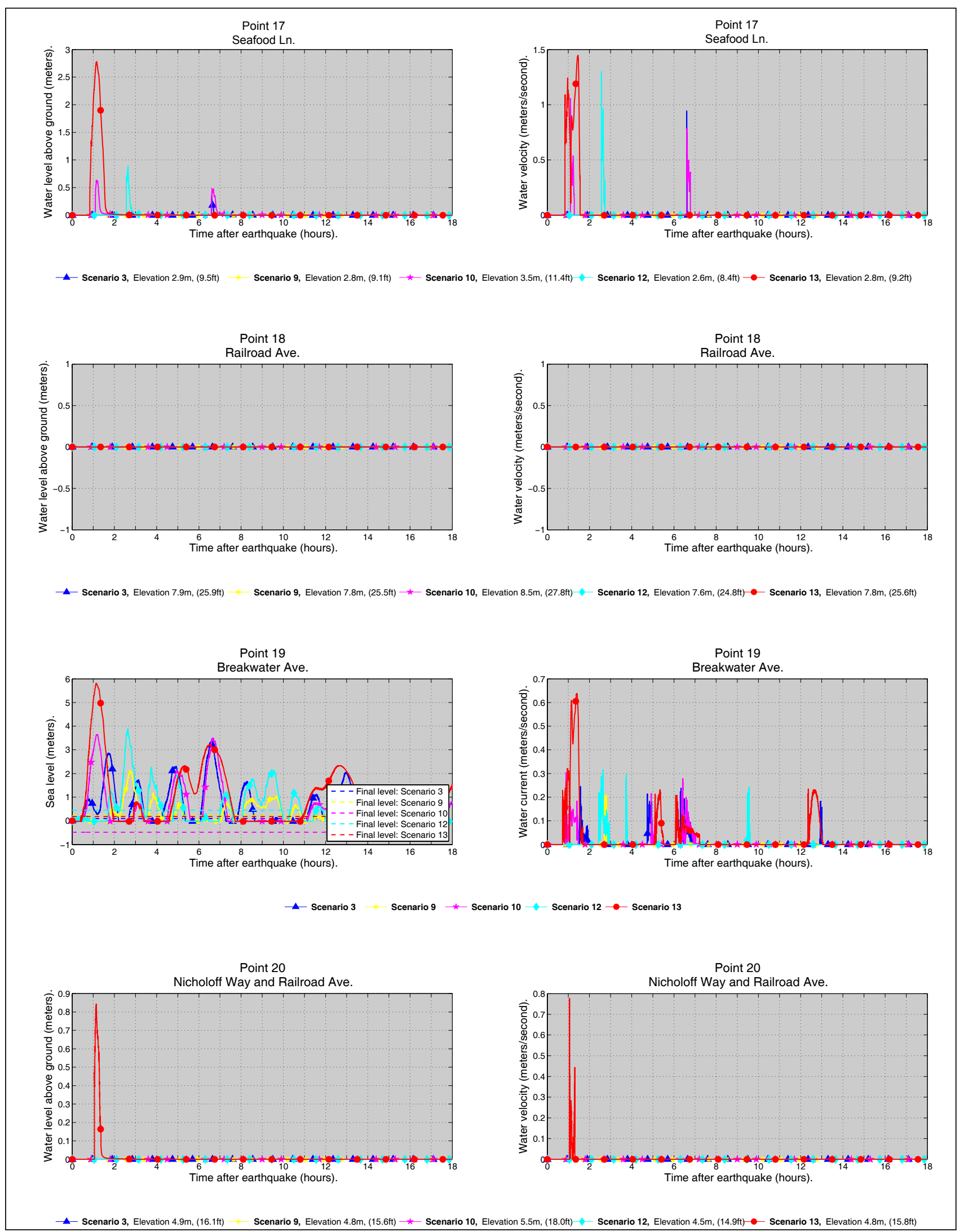




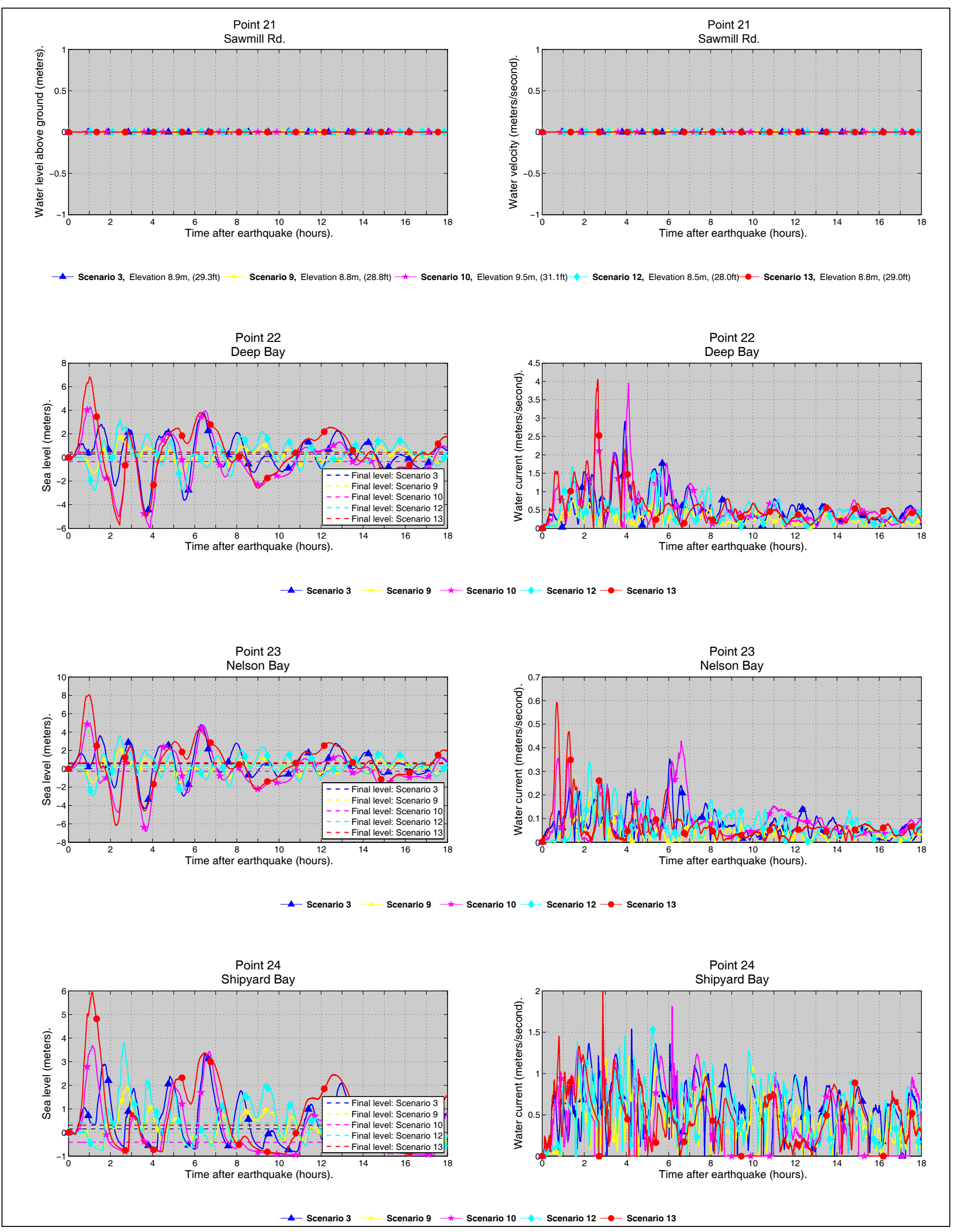




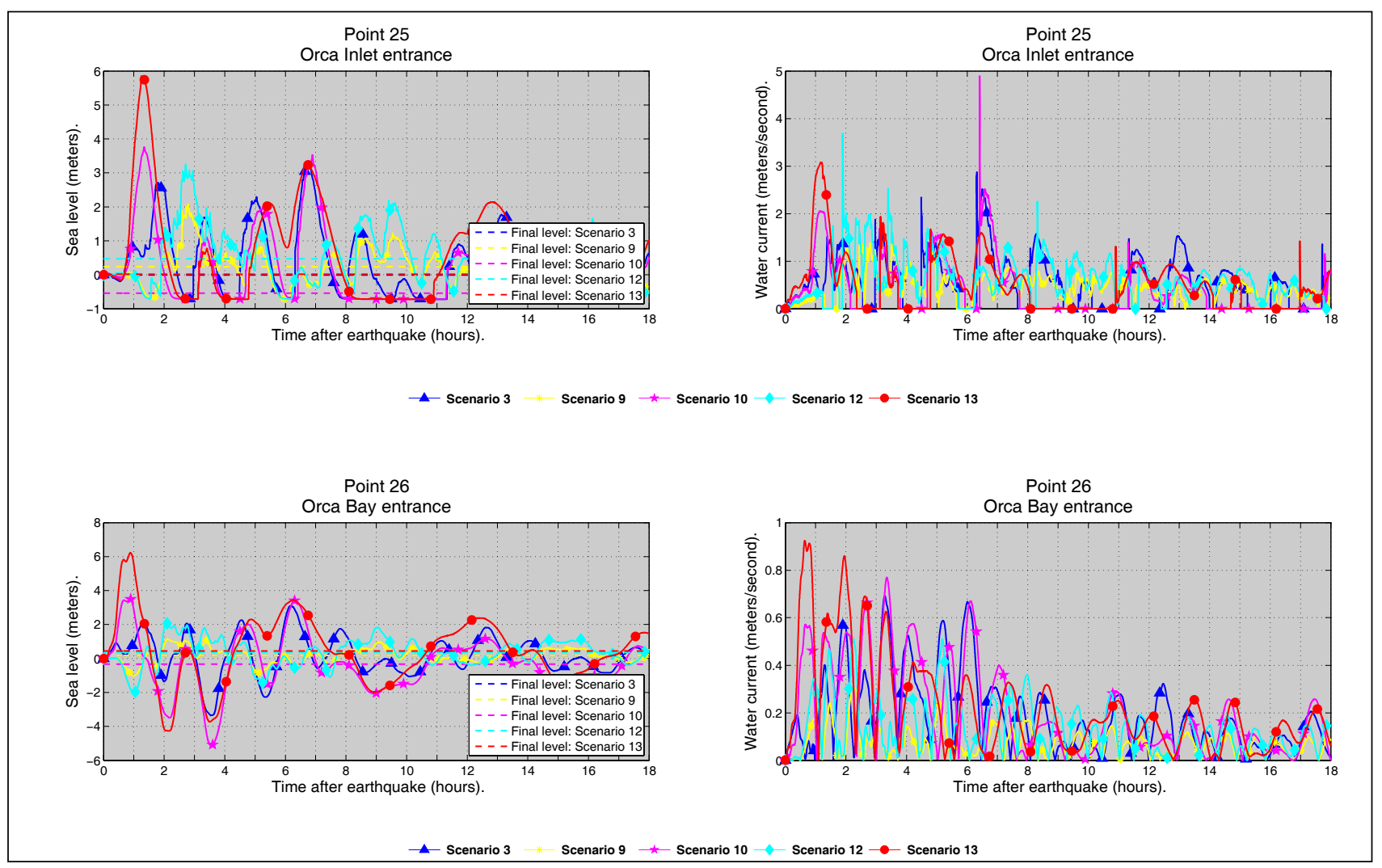




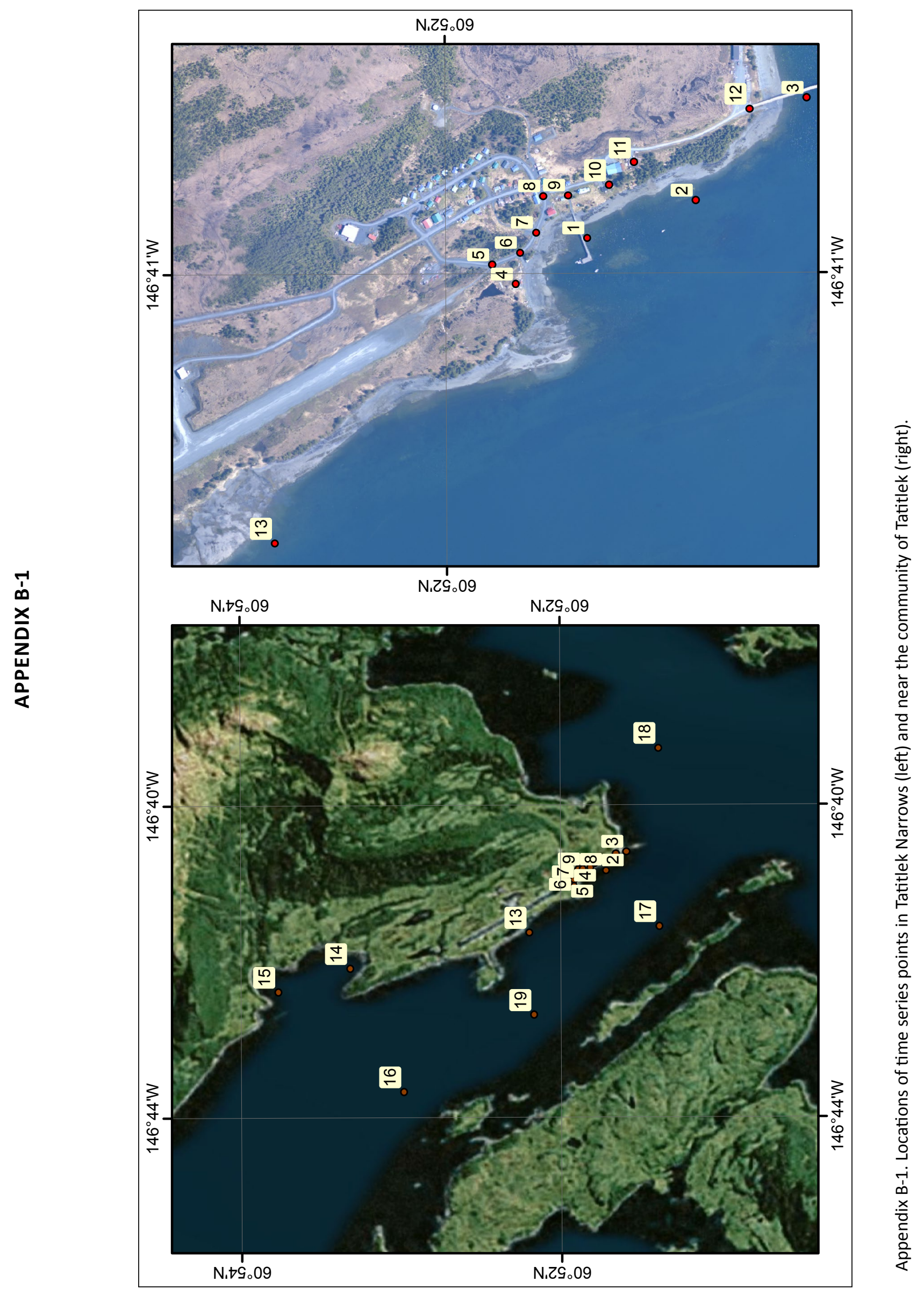




\section{APPENDIX B-2}

Time series of water level and velocity at selected locations in Tatitlek for scenarios 3, 9, 10,12, and 13. Elevations of onshore locations (left column) correspond to post-earthquake MHHW datum. For offshore locations, in order to show the height of an arriving tsunami, the vertical datum is such that zero corresponds to the pre-earthquake sea level.

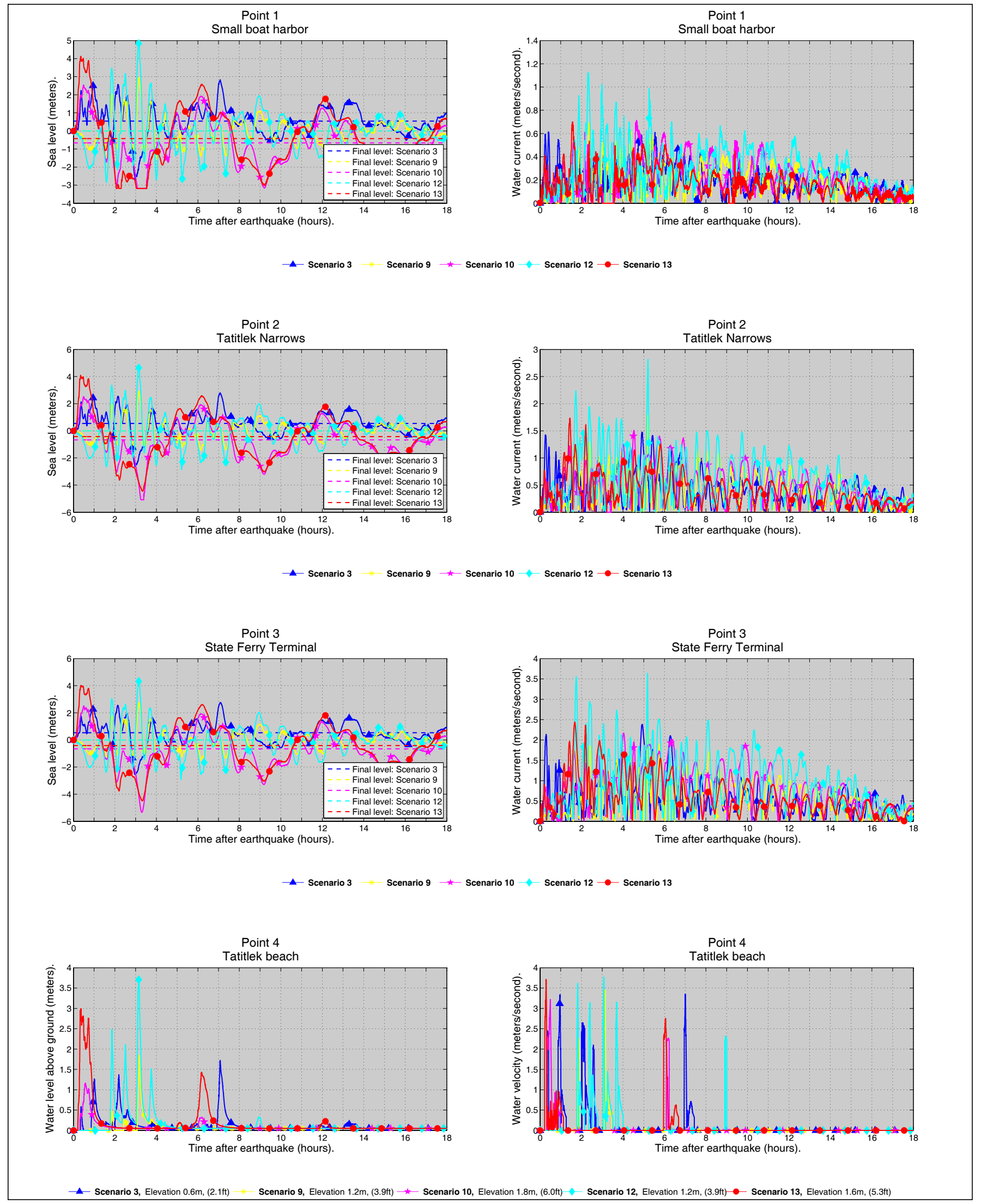




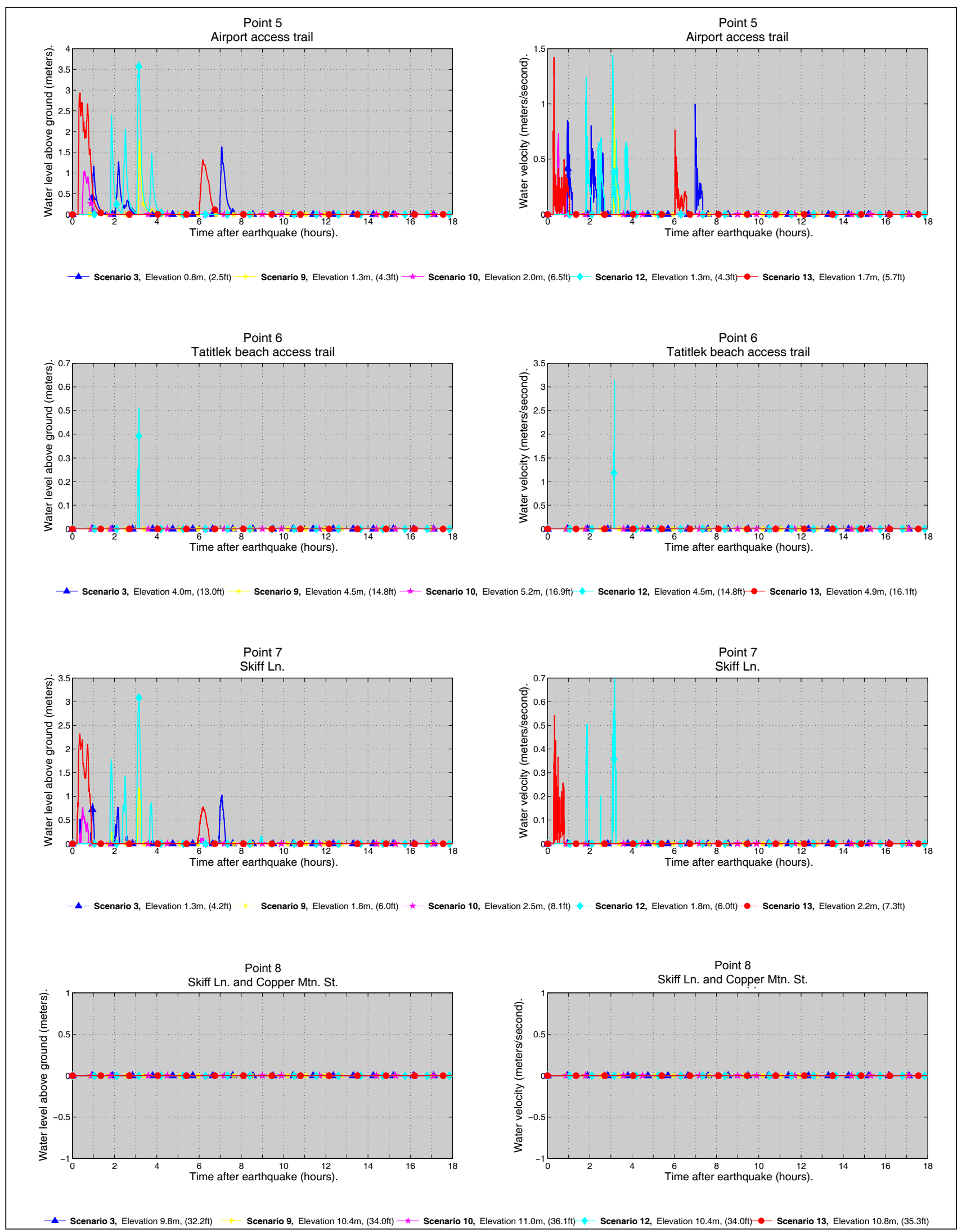




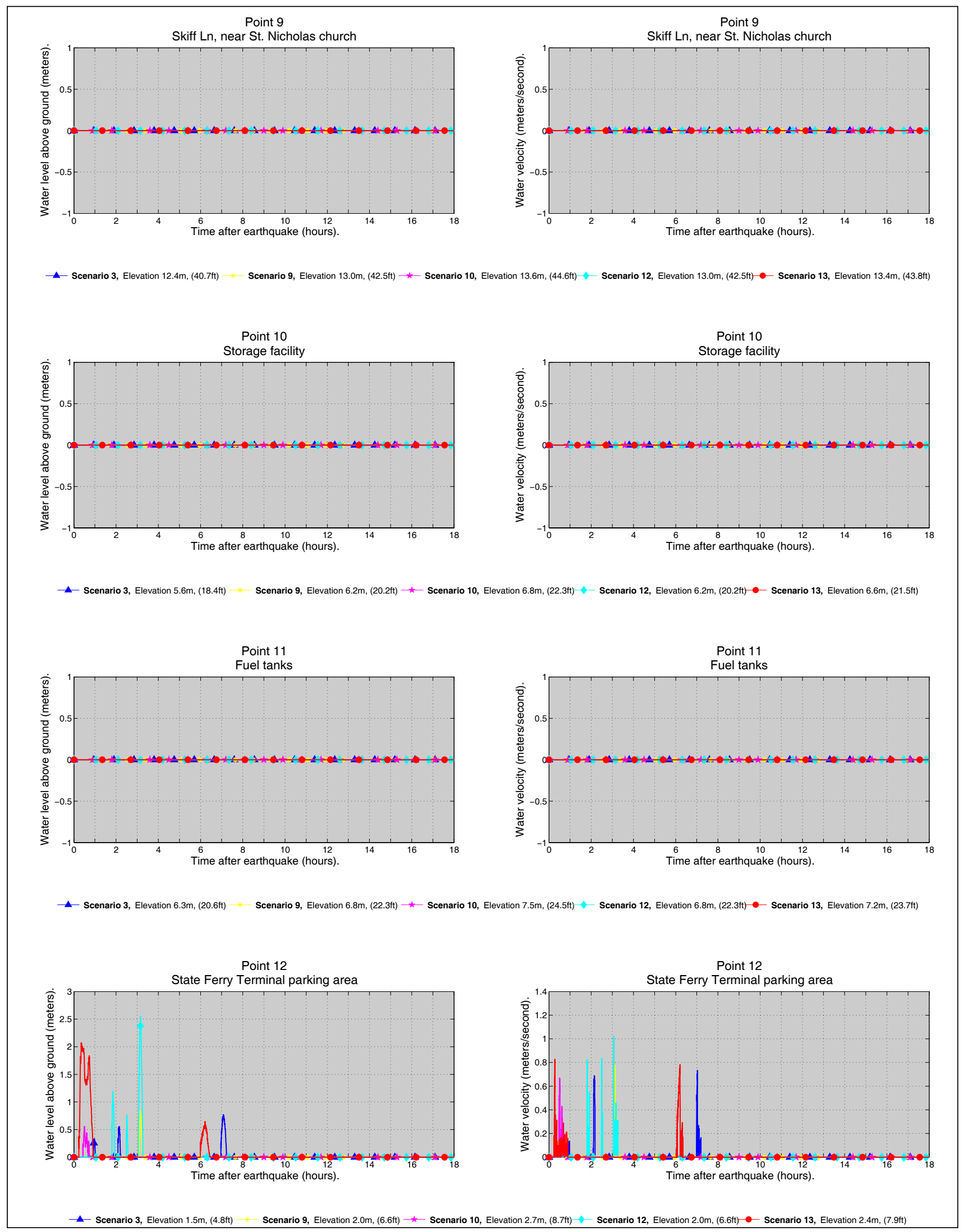




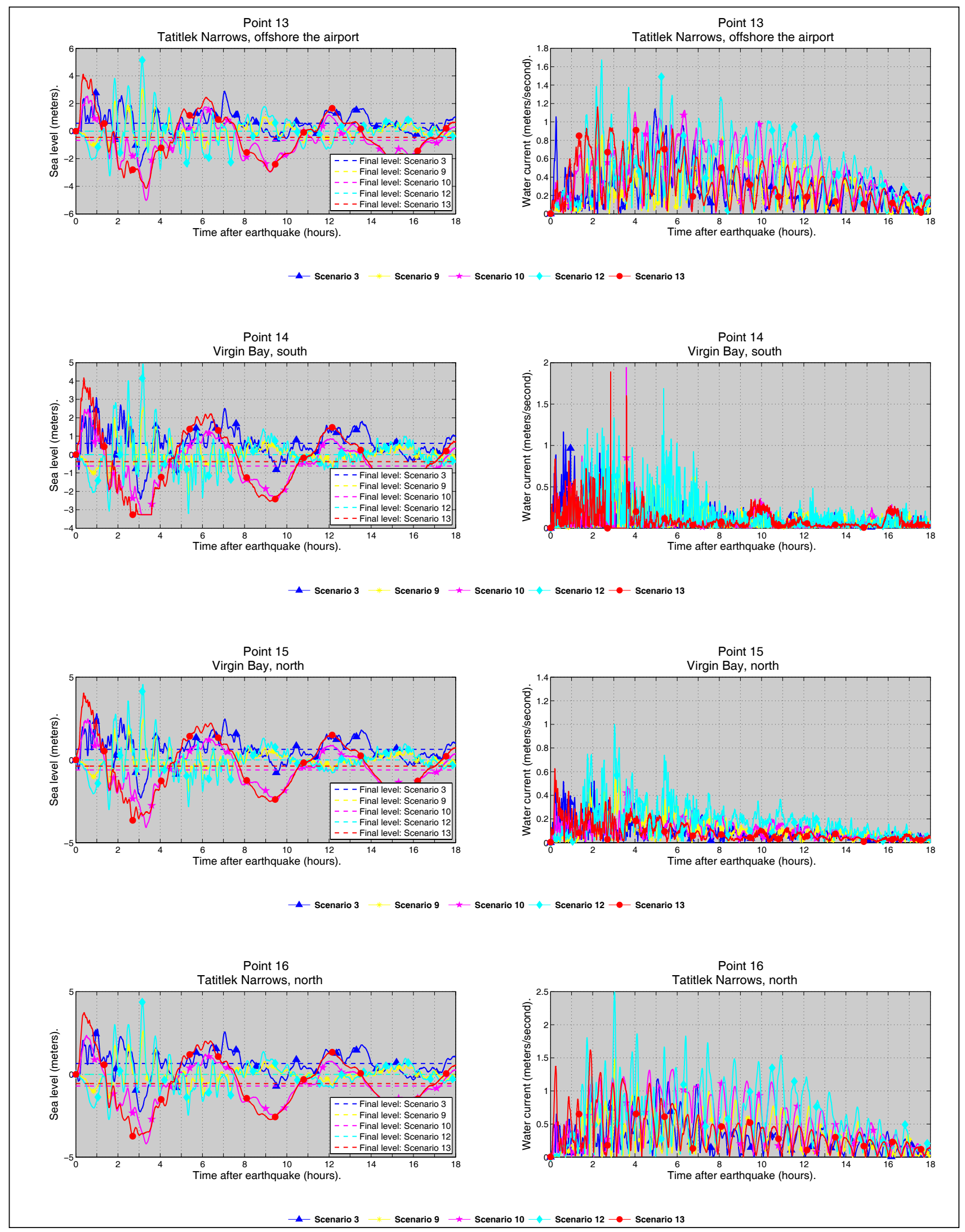




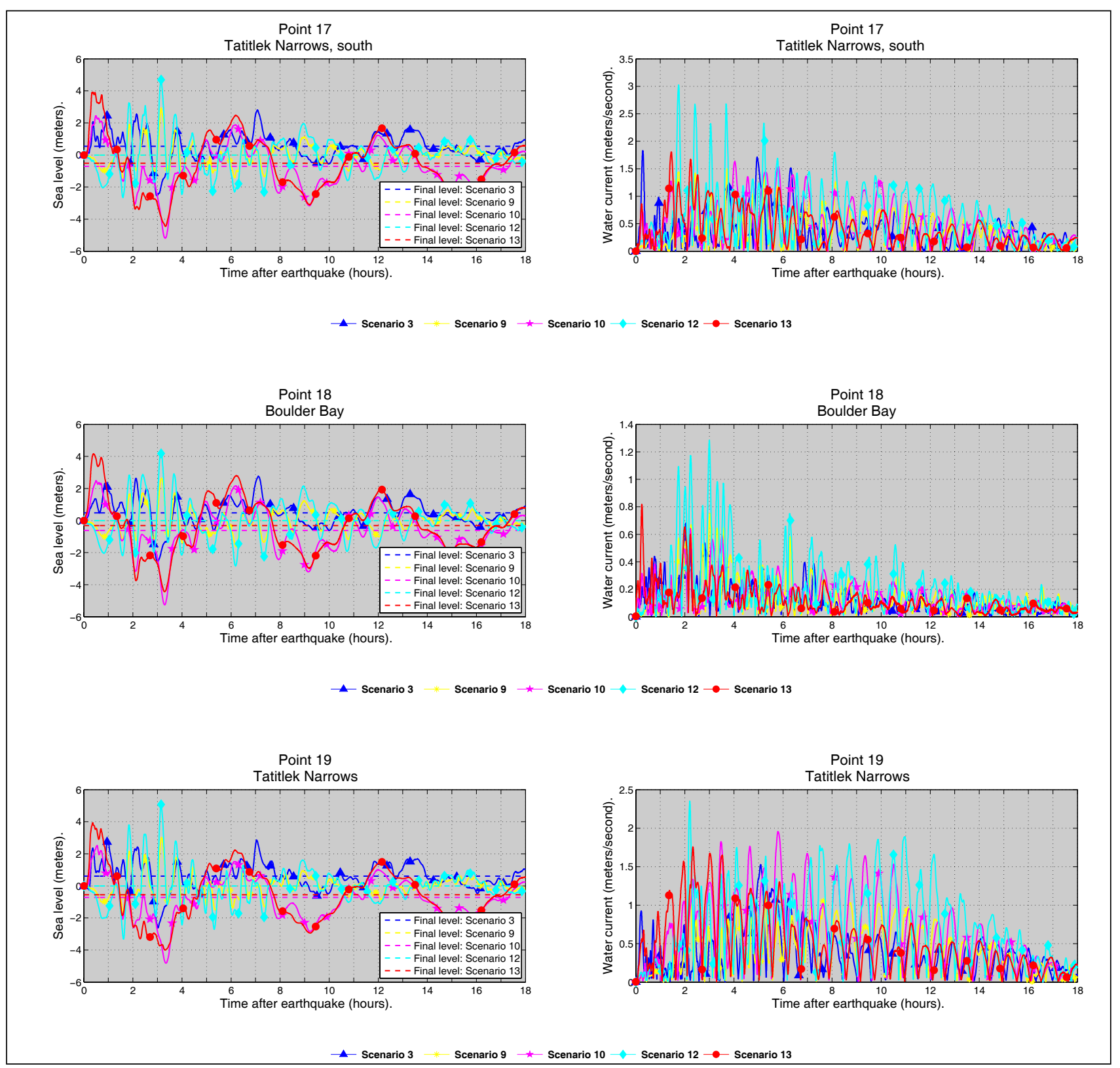




\section{APPENDIX C}

Cordova: Maximum composite potential inundation extent from all scenarios, and maximum composite flow depths over dry land. The DEM corresponds to the present-day MHHW datum.

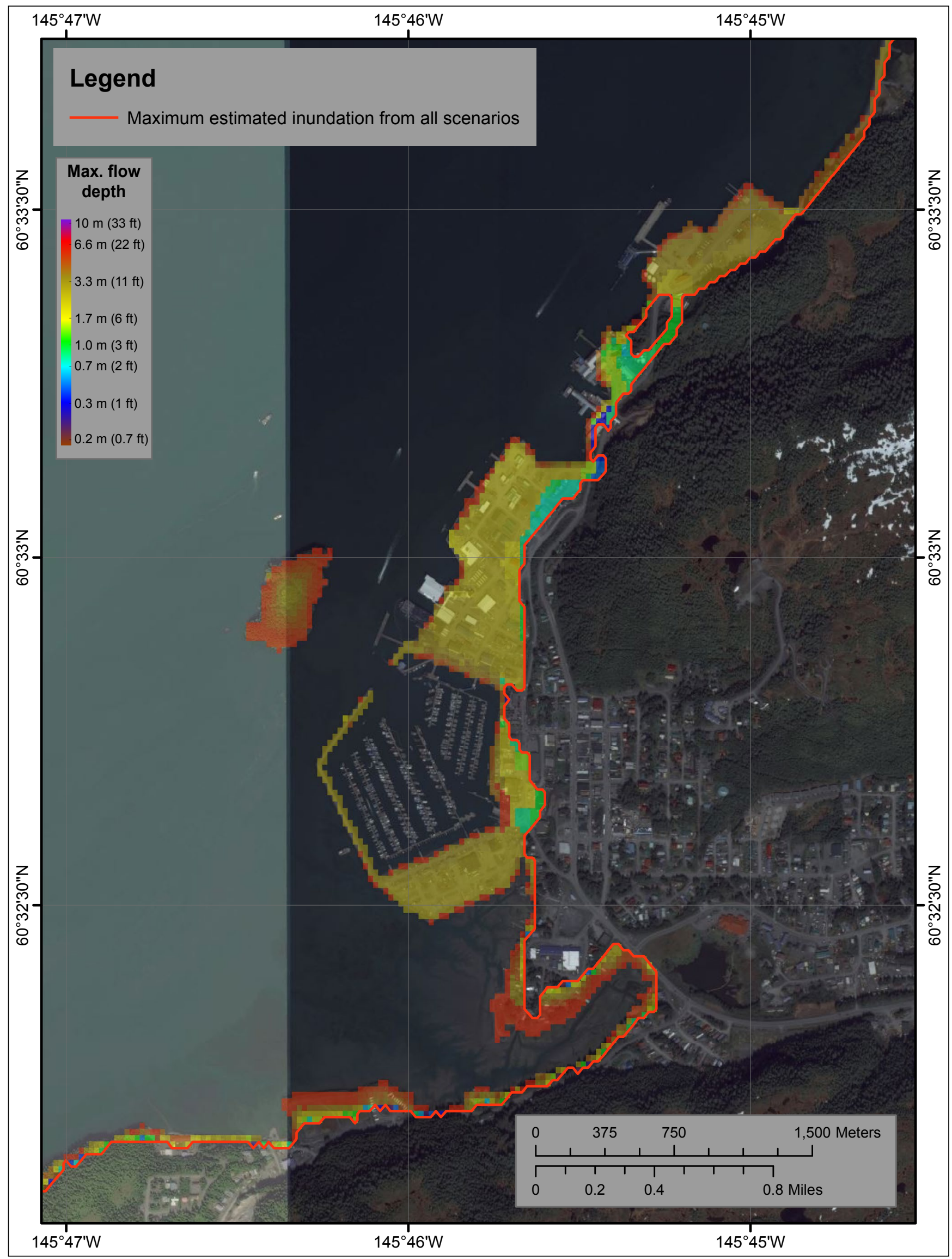




\section{APPENDIX D}

Tatitlek: Maximum composite potential inundation extent from all scenarios, and maximum composite flow depths over dry land. The DEM corresponds to the present-day MHHW datum.

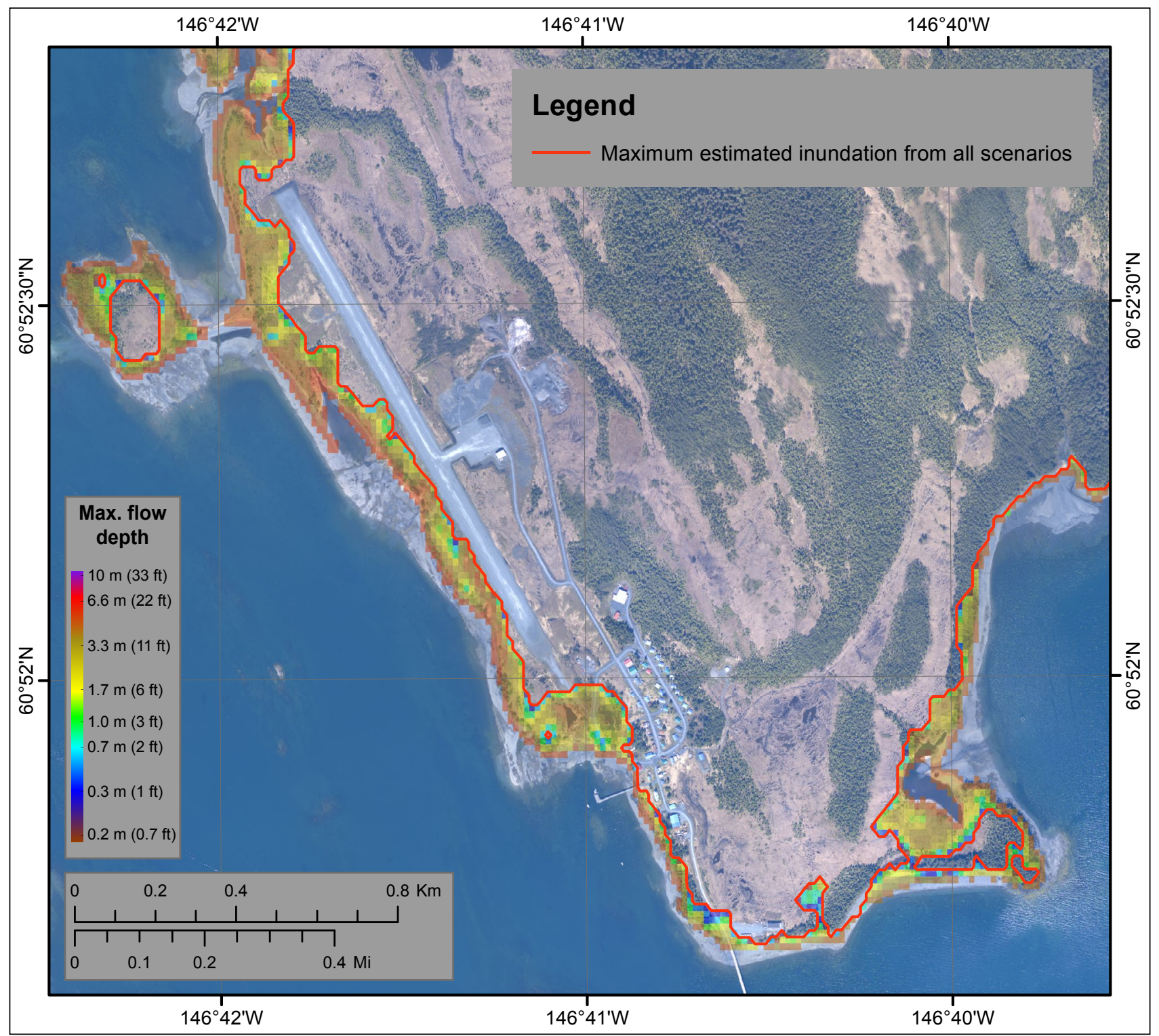

